\title{
"NEITHER STAUNCH FRIENDS NOR CONFIRMED FOES" NEW ZEALAND'S DEFENCE DIPLOMACY IN ASIA
}

\author{
BY
}

JUSTIN FRIS

A thesis submitted to the Victoria University of Wellington in fulfilment of the requirements for the degree of Master of Arts in International Relations

Victoria University of Wellington 


\begin{abstract}
Read a recent Defence White Paper of any number of countries or look at the range of foreign relations one country has with others in the contemporary age, and one is likely to come across the term 'defence diplomacy.' The traditional function of armed forces has been to prepare for and undertake the use of force. As part of this role, armed forces have cooperated with those of other nations to enhance security by countering or deterring potential enemies. In the post-Cold War era however, a new form of defence relations has emerged; in contrast to, yet supplementing their traditional role, armed forces have been employed in building cooperative relationships between former and potential future foes.
\end{abstract}

This shift is explained by the concept of defence diplomacy; the concept identified by Andrew Cottey and Anthony Forster that armed forces have a peacetime role in pursuit of broader foreign and security policy goals. Recognising that defence cooperation activities have a long history, Cottey and Forster differentiated defence diplomacy between 'old,' meaning those traditional defence cooperation activities aimed at allies and friendly states, and 'new,' meaning defence cooperation aimed at potential or former enemies.

New Zealand, like many other countries, has used the term since the 1990 s to describe those aspects of the diplomatic relationship, specifically peacetime cooperative activities, performed by the Ministry of Defence and the New Zealand Defence Force with the armed forces of other nations. This thesis explores the origins of defence diplomacy and the adoption of the concept by New Zealand. It looks at the way in which New Zealand has developed and managed its 'old' defence diplomacy in Asia through examining the example of the Five Power Defence Arrangements. It then explores New Zealand's 'new' defence diplomacy with what are considered here as "non-like-minded" states such as China, Viet Nam and Indonesia. Through these three case studies, the thesis examines key dilemmas and problems of defence diplomacy that have arisen in the development of these key relationships. The thesis then concludes with an analysis of New Zealand's defence diplomacy according to the framework established by Cottey and Forster. 


\section{Acknowledgements}

I wish to thank my supervisors Dr David Capie and Professor Robert Ayson for their ideas, research material, support and encouraging words.

I would like to thank all of those who gave their time to allow me to interview them for material. Former Defence Minister Dr Wayne Mapp, former Head of International Defence Relations Branch Paul Sinclair, former Commandant of the NZDF Command and Staff College Shaun Fogarty, former Defence Secretaries John McKinnon and Gerald Hensley, and former Ambassadors Tony Browne and Chris Elder all generously gave me their time to patiently respond to my questions. There were several others, being serving officials, whose interviews helped immensely but who could only speak freely on the condition of anonymity.

I wish to express my thanks to the staff of the Defence Library and Dr Mark Rolls of Waikato University for their assistance in finding research material. I also acknowledge the Victoria University Human Ethics Committee who approved the interview aspects of my data collection.

I am grateful to Neil Robertson for arranging access to the files of the Ministry of Foreign Affairs and Trade. Archives New Zealand staff were helpful in finding and retrieving files.

I am indebted to the New Zealand Army, and later the New Zealand Defence Force, who continued to support my research through the Educational Study Assistance programme.

Finally I wish to thank Vern Bennett for being the first to encourage me to undertake a thesis back in 2008 . 


\section{Table of Contents}

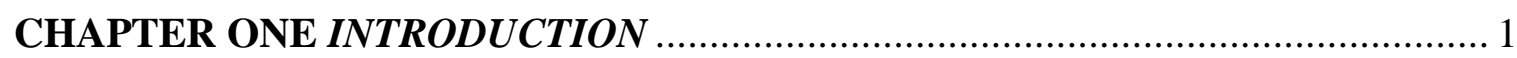

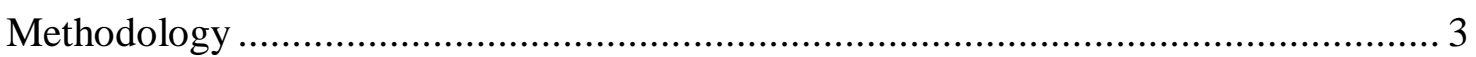

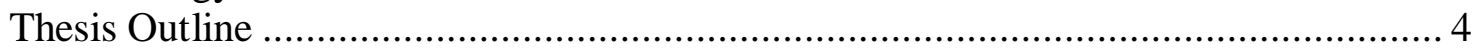

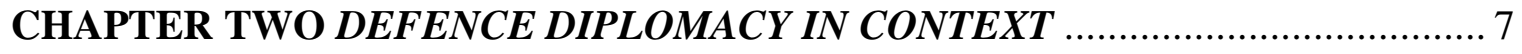

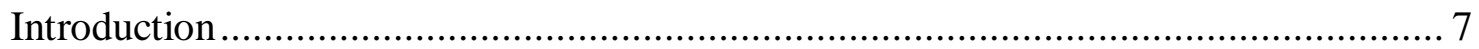

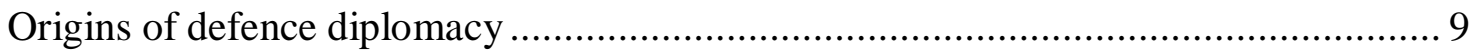

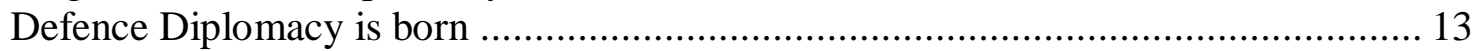

Britain's Defence Diplomacy after September 2001 ............................................ 16

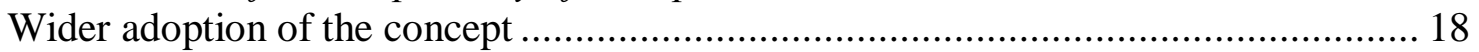

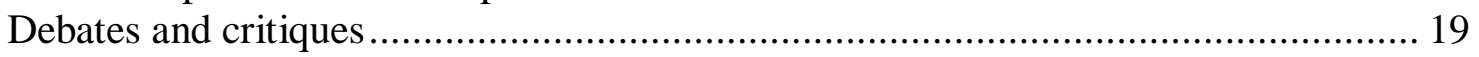

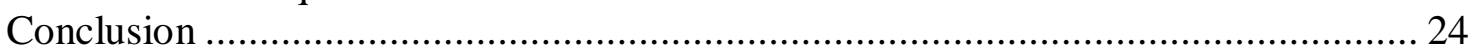

CHAPTER THREE NEW ZEALAND'S DEFENCE DIPLOMACY IN ASIA ........... 27

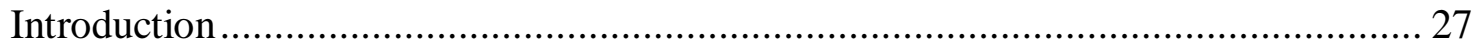

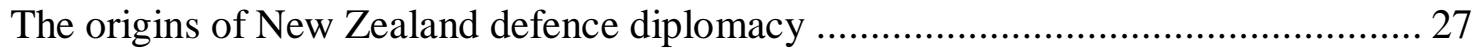

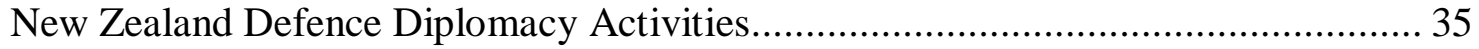

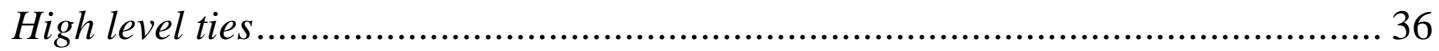

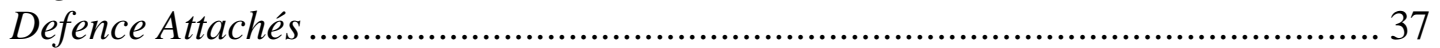

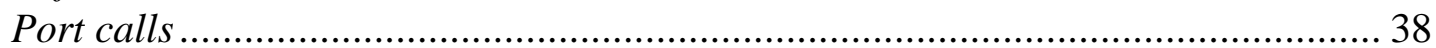

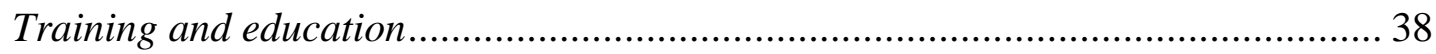

Exercises .......................................................................................... 40

New Zealand's 'old' Defence Diplomacy - The Five Power Defence Arrangements . 40

New Zealand's 'new' Defence Diplomacy............................................................... 45

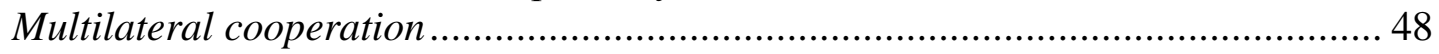

Issues and Dilemmas of New Zealand's Defence Diplomacy................................ 51

Balancing cooperation between 'old' and 'new' .............................................. 51

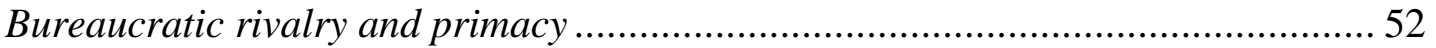

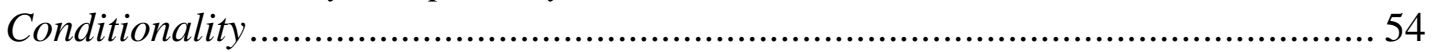

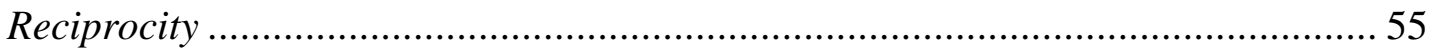

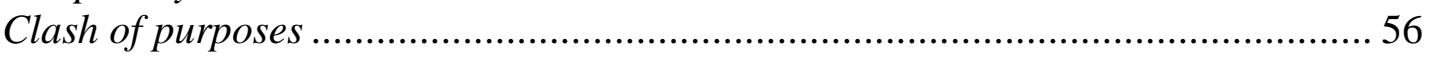

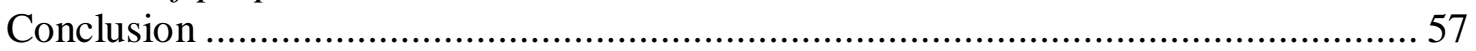

CHAPTER FOUR NEW ZEALAND'S DEFENCE RELATIONS WITH THE

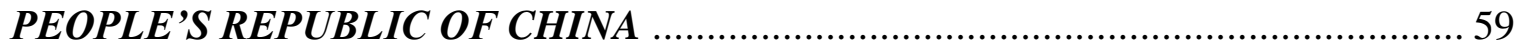

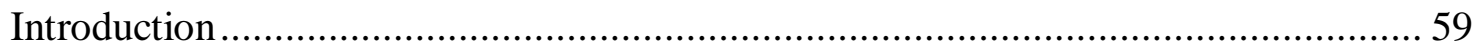

The development of Sino - New Zealand Defence Diplomacy ................................ 61

The purpose of Sino - New Zealand Defence Diplomacy ..................................... 63

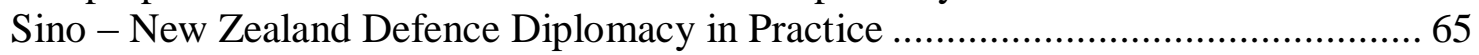

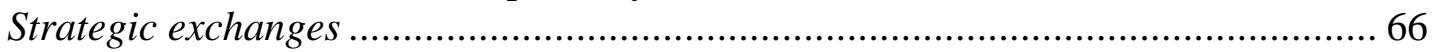

Functional and educational exchanges .............................................................. 70

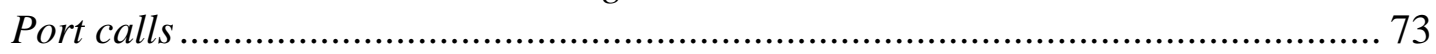

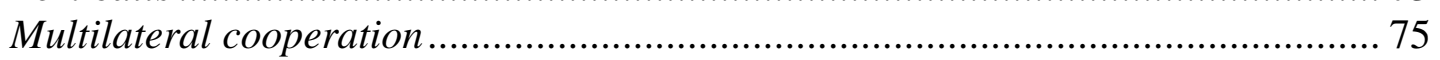

Issues in Sino - New Zealand Defence Diplomacy ............................................ 76

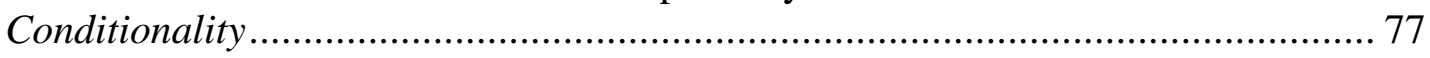

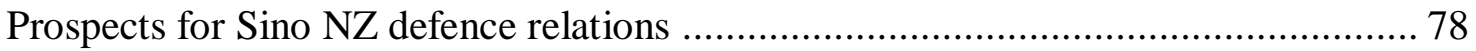

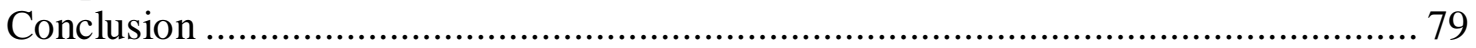


CHAPTER FIVE NEW ZEALAND'S DEFENCE RELATIONS WITH VIET NAM.81

Introduction and the development of Viet Nam - New Zealand Relations...................81

The Development of New Zealand's Defence Diplomacy with Viet Nam ..................83

Purposes of Viet Nam - New Zealand Defence Diplomacy ....................................86

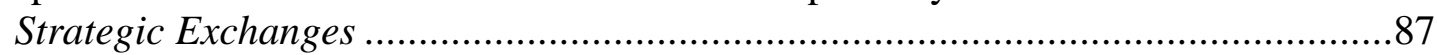

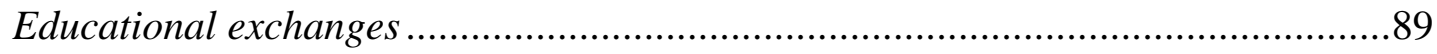

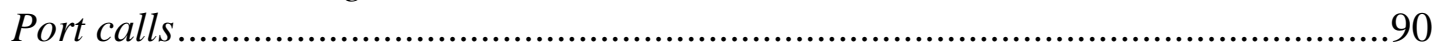

Multilateral cooperation....................................................................... 92

Issues arising from New Zealand defence diplomacy with Viet Nam .......................92

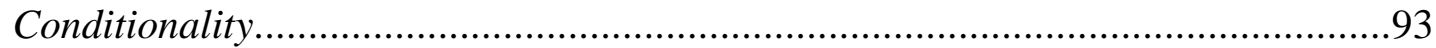

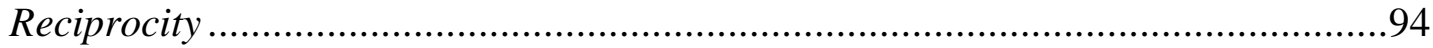

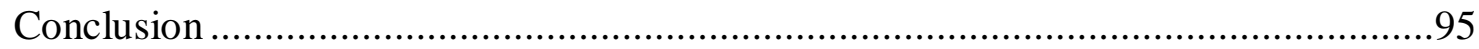

CHAPTER SIX NEW ZEALAND'S DEFENCE RELATIONS WITH INDONESIA 97

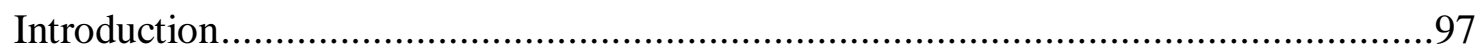

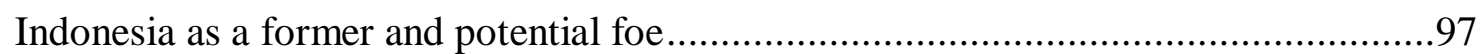

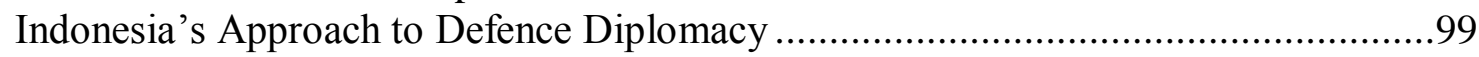

The Development of Indonesia - New Zealand Defence Diplomacy.......................101

The renewal of the Indonesia - New Zealand defence relationship ..........................105

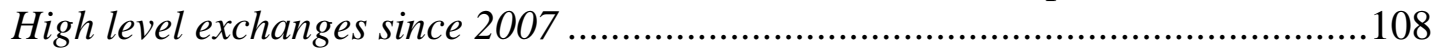

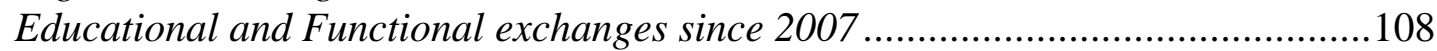

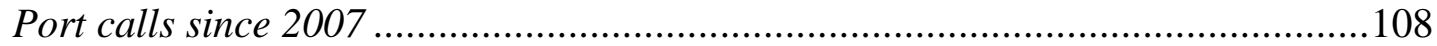

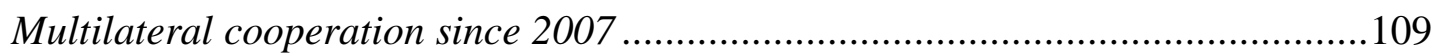

Issues in Indonesia-New Zealand Defence Diplomacy............................................110

Purposes of Indonesia - New Zealand Defence Diplomacy and its Dilemmas .......110

Reconciling the Indonesia - New Zealand defence relationship with the Five Power

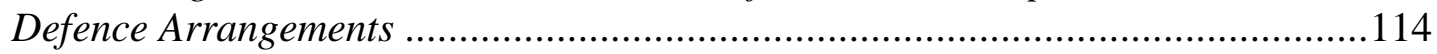

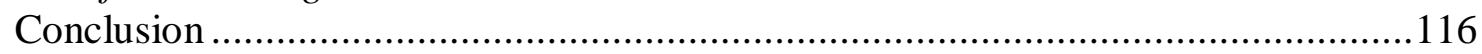

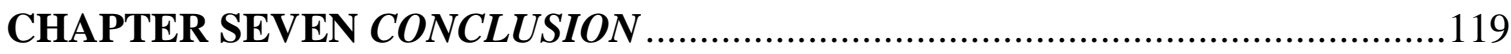

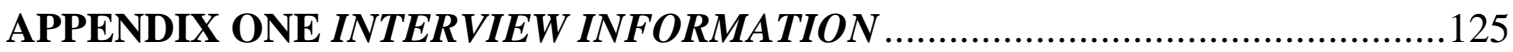

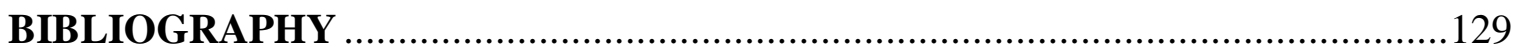

\section{List of Tables and Figures}

Table 1: United Kingdom Defence Diplomacy Activities ........................................15

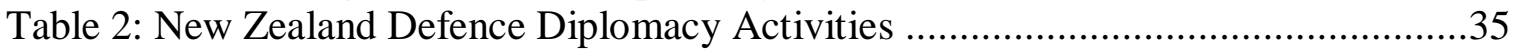

Table 3: High-Level Defence Exchanges between China and New Zealand since 1996 ..67

Table 4: Port calls conducted by China and New Zealand 1996 - 2012 ........................73

Table 5: High Level Defence Exchanges between New Zealand and Viet Nam ..............87

Table 6: Port calls conducted by Viet Nam and New Zealand 2001 - 2012 ....................90

Table 7: High-level Defence Exchanges between Indonesia and New Zealand since 2007

Table 8: Port calls conducted by Indonesia and New Zealand since 2007 109 


\section{Abbreviations}

\begin{tabular}{|c|c|}
\hline $\operatorname{ADMM}(+)$ & ASEAN Defence Ministers Meeting (Plus Eight) \\
\hline $\operatorname{ADSOM}(+)$ & ASEAN Defence Senior Officials Meeting (Plus Eight) \\
\hline ASEAN & Association of South East Asian Nations \\
\hline DIME & Diplomatic, Information, Military, Economic \\
\hline FPDA & Five Power Defence Arrangements \\
\hline HMNZS & Her Majesty's New Zealand Ship \\
\hline IDR & International Defence Relations \\
\hline IISS & International Institute for Strategic Studies \\
\hline JIDD & Jakarta International Defence Dialogue \\
\hline MAP & Mutual Assistance Programme \\
\hline MFAT & Ministry of Foreign Affairs and Trade \\
\hline MoD & Ministry of Defence \\
\hline NATO & North Atlantic Treaty Organisation \\
\hline NZDF & New Zealand Defence Force \\
\hline PACC & Pacific Armies Chiefs Conference \\
\hline PAMS & Pacific Armies Management Seminar \\
\hline PASOLS & Pacific Armies Senior Officer Logistics Seminar \\
\hline PLA & People's Liberation Army \\
\hline PLAAF & People's Liberation Army Air Force \\
\hline PLAN & People's Liberation Army Navy \\
\hline RNZN & Royal New Zealand Navy \\
\hline RNZAF & Royal New Zealand Air Force \\
\hline SDR & Strategic Defence Review \\
\hline SDSR & Strategic Defence and Security Review \\
\hline SEATO & South East Asian Treaty Organisation \\
\hline TNI & Tentara Nasional Indonesia \\
\hline UK & United Kingdom \\
\hline VPA & Viet Nam People's Army \\
\hline WPNS & Western Pacific Naval Symposium \\
\hline
\end{tabular}




\section{Chapter One Introduction}

Relationships between armed forces have extended back hundreds of years, as far back as the development of the modern nation state itself, and since this time these relationships have been inextricably linked to the defence and security needs of each nation. Typically, these defence relationships have grown out of alliances and other security arrangements between nations.

New Zealand, for its part, has maintained a range of such traditional defence relationships with states in Asia including Singapore, Malaysia, the Philippines and Thailand. The origins of these relationships lay in providing support to the security of allies and were primarily about countering common enemies. Cooperation and assistance took the form of the provision of training and conducting exercises to improve fighting abilities, to ensure equipment was maintained and available, and to improve the ability of these forces to operate alongside New Zealand forces and those of our major allies in the region in the event of conflict.

A feature of post-Cold War international relations was the introduction and use of the term 'defence diplomacy.' First coined by the United Kingdom in the late 1990s, the term described the increasing use of military cooperation and assistance beyond friendly states out to engage former and potential enemies. The term defence diplomacy, initially used by Western militaries to describe their engagement of the armed forces of the former Eastern Bloc, spread in popularity to the extent that most armed forces around the world now describe defence diplomacy in one form or another as a core task.

Defence diplomacy represented a shift in the nature of relationships between armed forces by extending defence cooperation beyond friendly allied states to former or potential enemies. A distinction can therefore be drawn between 'old' defence diplomacy, meaning traditional relationships with allies, and 'new' defence diplomacy, meaning engagement with non-like-minded states. This shift is examined in this thesis, particularly the way it has applied to New Zealand's new and established partners in Asia. Asia is the focus of this study because it is the location of both New Zealand's oldest formal alliance partners (Singapore and Malaysia) and the location of some of New Zealand's newest 
defence relationships (Viet Nam, China and the renewed relationship with democratic Indonesia).

The aim of the thesis is to determine whether New Zealand's defence relations have significantly changed in this period and whether its defence diplomacy also fulfils similar roles to those of other states such as the United Kingdom. This study will do so by examining New Zealand's defence links with our traditional security partners in Asia and then compare these with our developing relationships with the armed forces of non-likeminded nations.

Specifically, this thesis will ask:

- What explained the expansion of defence cooperation activities after the end of the Cold War?

- Where did defence diplomacy originate and how is it defined?

- When did New Zealand adopt the concept of defence diplomacy?

- How it has been employed by New Zealand and for what ends?

- Why do other countries engage with New Zealand armed forces?

- Are there different perspectives on defence diplomacy between the NZDF and the Ministry of Defence?

- Have defence diplomacy activities affected the conduct of traditional defence cooperation?

The thesis argues that while New Zealand was an enthusiastic early adopter of the concept, its use has been inconsistent and it has been employed for different purposes. It contends that there is an appreciable difference in the way it was perceived by different organs of the state, including between the New Zealand Defence Force, the Ministry of Defence and the Ministry of Foreign Affairs and Trade. Despite this, the distinction drawn between traditional and new forms of defence cooperation first identified by Cottey and Forster remains valid and New Zealand's defence diplomacy can be readily understood in that way. 
For the purposes of this thesis, defence diplomacy excludes treaties or formal alliances. Nor does it cover coercive diplomacy, such as gunboat diplomacy or other forms in which the military is used to apply or threaten to apply the use of force. Being focussed on Asia, this thesis also does not look at the particular obligations for defence New Zealand has towards the Cook Islands and Niue, or the treaty relationship with Samoa.

\section{Methodology}

Research for this study is based largely on a close reading and critical analysis of a wide range of primary and secondary sources. As the Royal United Services Institute, a UKbased independent defence and security think tank, noted in 2006:

Defence diplomacy continues to be given a relatively low profile... Specialist academics have conducted some conceptual analyses and there have been a number of studies of specific defence diplomacy initiatives, especially in conflict prevention. There has been very little comparative discussion of national and multilateral efforts in this dynamic policy area. $^{1}$

In this case, documents have been produced by foreign and defence ministries and armed forces, by non-governmental organisations, researchers and academics. They range from official reports, White Papers, policy papers, files and speeches, to journal articles and websites.

Material was obtained through a search of the internet and through a search of selected library databases. Most of the literature on the concept of defence diplomacy comes from the United Kingdom, which adopted the idea as a core part of defence policy, and the United States, with smaller amounts from Australia and New Zealand. There was a surprising amount of informative material originating within South East Asia in recent years.

As is to be expected with a topic like this, some material was not available because it remained classified in the files of the Ministry of Defence, the New Zealand Defence Force (NZDF) and the Ministry of Foreign Affairs (MFAT). MFAT generally releases

\footnotetext{
${ }^{1}$ Royal United Services Association, "Defence Diplomacy: Transatlantic Perspectives," no date, http://rusi.org/research/studies/transatlantic/news/ref:N4567118C822D6/.
} 
classified files into public archives, only after at least twenty years and sometimes not for 50 years. $^{2}$ In this case, MFAT files did prove a useful source for historical information.

Because of the dearth of primary material available on New Zealand's conduct of defence diplomacy it became necessary to conduct interviews with decision-makers and those involved with carrying out New Zealand's defence diplomacy. In total, nine interviews were conducted. They were approximately 30 minutes in length (but some extended up to over an hour) and were semi-structured. A sample question list was prepared, based around a fixed set of questions about the development of defence relations and their purposes. As each interview progressed however, points made could be elaborated upon or new lines of exploration pursued as they came up.

The interviews were conducted in the final stages of the writing process. They not only provided a wealth of new material, but also enabled the initial conclusions derived from analysis of secondary sources to be confirmed or reconsidered. The study was limited in that only no officials of China, Viet Nam or Indonesia were interviewed and information about their perspectives had to be drawn from their respective defence policy, academic papers or from third country analysis (mostly originating in the United States).

\section{Thesis Outline}

Before examining New Zealand's conduct of defence diplomacy, one needs to understand the context and origins of the concept itself. Chapter Two attempts to describe the etymology of defence diplomacy. What is it? Where did it come from? What accounts for the term's recent rise? How are the various forms of defence diplomacy differentiated? To what purposes is it used? This chapter goes on to describe the criticism and debates the concept has generated, as well as some of the issues that arise when carrying out defence diplomacy.

Chapter Three focuses more on the practice of New Zealand's defence diplomacy. The first part reviews when and how New Zealand has employed the term, and then goes on to discuss the broad range of defence activities that comprise New Zealand defence

\footnotetext{
${ }^{2}$ New Zealand Ministry of Foreign Affairs and Trade, "MFAT Releases Classified Files to Public," August 2, 2012, http://www.mfat.govt.nz/Media-and-publications/Features/415-MFAT-Releases-ClassifiedFiles.php.
} 
diplomacy. In order to illustrate the distinction between 'old' and 'new' defence diplomacy, it includes a discussion about New Zealand's primary and long-standing defence relationship in Asia, the Five Power Defence Arrangements (FPDA). This provides insights into how 'old' defence diplomacy works. A subsequent section examines 'new' defence diplomacy and introduces some of the dilemmas and issues caused by its conduct. It also provides an introduction to the three case studies in which these dilemmas and issues can be explored in more detail.

Chapter Four, the first of the case studies, explores the development of New Zealand's defence diplomacy with China's People's Liberation Army (PLA). The relationship with the PLA could be considered the first and the most extensive of New Zealand's 'new' defence diplomacy ties. This case study builds on existing writing on Sino-NZ relations, exploring the bilateral defence relationship, which is often neglected. The case study will also add to the body of work on China's defence relations with other countries, particularly the United States and Australia, complementing these works by providing a small nation perspective. It places Sino-New Zealand defence diplomacy within the context of the development of New Zealand's wider political and economic relationship and presents research gathered on the metrics of Sino-New Zealand defence engagement. It also seeks to identify what the PLA is seeking from its relationship with New Zealand. The chapter analyses those dilemmas and issues posed by the NZDF-PLA relationship and concludes with a short analysis of the prospects for the defence relationship.

Chapter Five looks at the Viet Nam - New Zealand defence relationship, examining how defence relations between these two former adversaries came about. What does each side seek from defence engagement? How have issues such as conditionality and reciprocity affected the relationship? Viet Nam represents another useful example of where defence diplomacy and the interests of 'New Zealand Inc' coincide and how defence relations fulfil wider foreign policy objectives. Engagement with Viet Nam is also particularly poignant considering New Zealand's contribution to the Vietnam War.

New Zealand's defence diplomacy with Indonesia presents a different case to China and Viet Nam. It provides a key example in which to explore the issue of conditionality and the debate around defence engagement with non-democratic regimes, particularly military dictatorships. Chapter Six examines the long history of New Zealand defence relations 
with Indonesia in two phases: up to 1999 and after 2000, in order to understand the way in which the application of conditions and the wider dilemma of engagement with authoritarian regimes has played out for New Zealand.

The thesis closes with a brief conclusion that draws together the main findings from the cases and discusses the importance of defence diplomacy in contemporary New Zealand defence relations. 


\section{Chapter Two Defence Diplomacy in Context}

Better to send middle aged men abroad to bore each other, than send young men abroad to kill each other.

Robin Cook, former United Kingdom Foreign Secretary

\section{Introduction}

The traditional role of the armed forces is the use of force, or the threat thereof, for the purposes of defence, deterrence, compulsion or intervention. But armed forces have also traditionally had another role; cooperating with other militaries. Armed forces have developed ties with their allies around the world; providing arms, military training and other forms of assistance, as well as engaging in bilateral and multilateral defence cooperation.

Since the end of the Cold War, the lines between defence, security and foreign policy issues have become increasingly blurred. Within this context, the defence cooperation role of the armed forces has also changed. Defence ministries and militaries have taken on a wider range of peacetime cooperative and assistance tasks, and have operated more as a tool of foreign and security policy. There has been recognition that war is not the only means of international policy to which armed forces are suited. Activities such as security sector reform that seek to develop appropriate, legitimate and effective security forces in countries susceptible to state weakness and challenges to their legitimacy are a response to the emerging security challenges of the post-Cold War period. More generally, armed forces have been rebalancing their effort towards proactive, long-term engagement activities; building trust to achieve influence as recognition has grown that greater emphasis needs to be placed on prevention of conflict, as opposed to the conduct of conflict. This development became known as defence diplomacy. 
What then does the term mean? Broadly speaking, defence diplomacy can be regarded as the peacetime cooperative use of armed forces as a tool of foreign and security policy. ${ }^{3}$ Defence diplomacy has been described as "one of the organising principles used to help the West come to terms with the new international security environment."4 It becomes problematic when trying to further define the term as it has been used to describe a multitude of activities and tends to mean different things to different people within different organisations. A variety of defence cooperation activities and their purposes are often confused together under this umbrella term. Defence diplomacy is used at different levels; on one hand being used as an all-encompassing term for various types of military cooperation activities, while on the other it is often regarded as a discrete activity that is a subset of other types of military engagement. It also goes by many other names such as military diplomacy, defence cooperation, or military cooperation. China for example defines military diplomacy as "all diplomatic activities relating to national security and military diplomatic activities", differentiating this from political diplomacy which is conducted by civilian or diplomatic officials. ${ }^{5}$

Sometimes defence diplomacy is defined by its purposes. At a high level, some regard defence diplomacy as gestures of goodwill towards friendly countries. ${ }^{6}$ Another definition of defence diplomacy, influenced by British defence policy, was the "use of military personnel, including service attachés, in support of conflict prevention and resolution. Among a great variety of activities, it included providing assistance in the development of democratically accountable armed forces."7 Anton Du Plessis, a South African academic, looks at defence diplomacy as a form of diplomacy and argued that the UK definition was distinct because of its security domain, military nature, and coercive or non-coercive use of force function. ${ }^{8}$ In an interesting development, and one that further confused the issue, the United States recently began using the term defence cooperation as a euphemism for

\footnotetext{
${ }^{3}$ Andrew Cottey and Anthony Forster, Reshaping Defence Diplomacy: New Roles for Military Cooperation and Assistance, Adelphi Papers 365 (Oxford; New York: Oxford University Press for the International Institute for Strategic Studies, 2004), 6.

${ }^{4}$ Wolfgang Koerner, Security Sector Reform: Defence Diplomacy, In Brief (Ottawa, Canada: Parliamentary Information and Research Service, 2006), 2, www.parl.gc.ca/Content/LOP/researchpublications/prb0612e.pdf.

${ }^{5}$ Yasuhiro Matsuda, "An Essay on China's Military Diplomacy: Examination of Intentions in Foreign Strategy," in NIDS Security Reports, No 7, 2006, 5, www.nids.go.jp/english/publication/kiyo/pdf/bulletin_e2006_2_Matsuda.pdf.

${ }^{6}$ John Leech, Asymmetries of Conflict: War Without Death (London: F. Cass, 2002), 61.

${ }^{7}$ Geoffrey R Berridge and A James, A Dictionary of Diplomacy (Basingstoke: Palgrave, 2001), 66.

${ }^{8}$ Anton du Plessis, "Defence Diplomacy: Conceptual and Practical Dimensions with Specific Reference to South Africa" (Institute for Strategic Studies, 2008), 92.
} 
arms sales. ${ }^{9}$ Regardless of the nomenclature, the key development in this regard has been the extension of defence cooperation to the armed forces of former or potential adversaries, or for the purposes of this study what are termed 'non-like-minded' states, something described by Andrew Cottey and Anthony Forster as 'new' defence diplomacy. ${ }^{10}$ The key characteristic of 'new' defence diplomacy that distinguishes it from other forms of military cooperation is its focus on former and potential adversaries towards helping build cooperative relationships (what they referred to as strategic engagement); promoting democratic civilian control of armed forces and supporting regimes to develop peacekeeping capabilities. This study focuses on the cooperative, non-coercive military to military contacts "with countries that are, as United States General Henry Shelton put it "neither staunch friends nor confirmed foes."11

\section{Origins of defence diplomacy}

The range of activities that are generally understood as occurring under the broad rubric of defence diplomacy have a long history. One of the earliest forms of defence diplomacy occurred during the Thirty Years War (1618 to 1648), when the Duke of Richelieu dispatched French military officers abroad in order to liaise with allies, monitor military developments and gather intelligence. ${ }^{12}$ In the 18th century, this activity was formalised with the practice of assigning defence attachés to embassies, and by the 19th century most countries had defence attachés, facilitated by the emergence of national defence establishments and the building of colonial empires. ${ }^{13}$ Other notable events that might now be considered examples of defence diplomacy were the circumnavigation of the globe by the United States Navy's Great White Fleet, and the establishment in 1927 by the United Kingdom (UK) of the Imperial Defence College intended to train officers from the British Commonwealth and develop common doctrine. ${ }^{14}$

\footnotetext{
9 Surya Gangadharan, "US Courts India, Says Sensitive Weapons Tech Deals No Taboo," India Global, July 24, 2012, http://ibnlive.in.com/news/us-courts-india-says-no-taboo-on-sensitive-weapons-tech/27409361.html.

${ }^{10}$ Cottey and Forster, Reshaping Defence Diplomacy, 8.

${ }^{11}$ Henry H. Shelton, "Shaping a Better World: Military Engagement in Peacetime," US Foreign Policy Agenda, December 1999, 7-8, http://www.usia.gov/journals/itps/1299/ijpe/ijpe1299.htm.

${ }^{12}$ David Law (Editor), "Defence Attachés" (Geneva Centre for the Democratic Control of Armed Forces (DCAF), Geneva, Switzerland, July 2007), 2.

${ }^{13}$ Ibid.

${ }^{14}$ Cottey and Forster, Reshaping Defence Diplomacy, 6.
} 
Befitting its post-Cold War origins, what we now understand as defence diplomacy first emerged in Germany at the beginning of the 1990s. Germany had been providing defence assistance to the former Soviet Union as early as 1990 to facilitate the withdrawal of Russian forces stationed in the former East Germany. ${ }^{15}$ It was not until 1994, however, that the German Ministry of Defence identified 'military-political' cooperation with former Warsaw Pact countries as among the core missions of its armed forces. Reflecting a recognition that traditional perspectives of security were broadening and the role of the military went beyond deterrence and defence, the 1994 German Defence White Paper identified the need for the employment of a wide-ranging set of foreign and security policy tools for the early detection and, where possible, resolution of conflicts before they assumed a military dimension. ${ }^{16}$

This new outlook was enabled by the end of the Cold War and the opening up of new policy options. The Germans not only recognised that their security was directly affected by how the situation in Central, Eastern and South Eastern Europe developed, ${ }^{17}$ but also began to look beyond Europe, identifying the need to promote disarmament and demobilisation, particularly in Africa, Asia and Latin America. What is significant though, is that it was the Bundeswehr, the German armed forces, who were tasked with fostering international cooperation and integration, especially in Europe, by training the armed forces of the new democracies; by promoting dialogue on military policy; by participating in visits and exchange programmes for military personnel and in combined North Atlantic Treaty Organisation (NATO) and Western European Union exercises; and by sending personnel to observe United Nations and Commission on Security and Cooperation in Europe missions and to verify compliance with arms control agreements.

Another development that originated around the same time was Partnership for Peace, initiated by NATO in 1994. Partnership for Peace was aimed toward building trust and confidence between NATO members and other states in Europe, notably those in the

\footnotetext{
${ }^{15}$ Sidney Bearman, ed., "New Challenges to Defence Diplomacy,” Strategic Survey 1999/2000 100, no. 1 (January 1999): 39.

${ }^{16}$ Federal Ministry of Defence, White Paper on the Security of the Federal Republic of Germany and the Situation and Future of the Bundeswehr (Bonn: Press and Information Office of the Federal Government, 1994), para. 212, http://www.resdal.org/Archivo/Falem-cap1.htm.

${ }^{17}$ Ibid., para. 311.
} 
former Warsaw Pact and the former Soviet Union. ${ }^{18}$ Each state was engaged bilaterally by NATO across a range of defence activities, with their level and pace aligned with that state's own priorities, ambitions and abilities. Such activities included defence reform, policy and planning, civil-military relations, education and training, military to military cooperation and exercises, all aimed at supporting the individual state's domestic reform. ${ }^{19}$ Partnership for Peace paved the way for some of these nations to join NATO peacekeeping operations in the former Yugoslavia, and later to join NATO itself, and the programme remains operational to this day.

Around the same time, the United States military was formulating similar concepts such as preventative defence, which was introduced by then Secretary of Defense William Perry in 1996 to describe the United States' programme of bilateral military exchanges with Russia. $^{20}$ The United States has long had a well-developed sense of the military's role alongside other elements of national power. They consider relations between states in terms of 'DIME' - diplomatic, information, military, and economic elements of national power. $^{21}$ In the context of DIME, the military was a core diplomatic channel through which conflicts can be resolved or prevented in the first place.

The American form of defence diplomacy was part of a wider concept of defence engagement which covered two groups of military activity. The first group was Foreign Military Interaction $^{22}$ which included military assistance, military education, joint planning, exercises and operations, while the second group was defence diplomacy. In the American context, this was an unofficial term used to describe military and defence support of foreign policy in peacetime. The difference between the two groups was that defence diplomacy activities usually occurred in a policy vacuum, were undeveloped, unfunded and not based on legislation, in contrast to Foreign Military Interaction activities which were. ${ }^{23}$

\footnotetext{
${ }^{18}$ North Atlantic Treaty Organisation, 'The Partnership for Peace programme' http://www.nato.int/cps/en/natolive/topic_50349.htm 05 March 2012.

${ }^{19}$ Ibid

${ }^{20}$ Bearman, "New Challenges to Defence Diplomacy," 39.

${ }^{21}$ R. Craig Nation, "National Power," in Guide to National Security Issues: Theory of War and Strategy, ed. J. Boone Bartholomees, vol. 1, 3rd ed. (Carlisle, PA: U.S. Army War College, 2008), 165.

${ }^{22}$ United States Joint Staff, "Chairman of the Joint Chiefs of Staff Manual (CJCSM) 3113.01 Theater Engagement Planning,” February 1, 1998, A10, https://www.hsdl.org/?view\&did=2026.

${ }^{23}$ Alice Hills, "Defence Diplomacy and Security Sector Reform," Contemporary Security Policy 21, no. 1 (2000): 61.
} 
The Americans considered defence engagement as a "shaping" activity. ${ }^{24}$ Shaping meant creating and preserving "conditions for the success of the decisive operation... by affecting enemy capabilities and forces, or by influencing enemy decisions." 25 The US National Military Strategy defined shaping in the following way:

US armed forces help shape the international environment primarily through their inherent deterrent qualities and through peacetime military engagement. The shaping element of our strategy helps foster the institutions and international relationships that constitute a peaceful strategic environment by promoting stability; preventing and reducing conflict and threats; and deterring aggression and coercion. ${ }^{26}$

This approach to defence diplomacy was criticised. Thomas Jordan and others pointed out that "shaping" occurred in all American defence cooperation and it was somewhat contentious that the US performed 'shaping' of even developed democracies and global allies such as Canada and NATO countries. ${ }^{27}$

Closer to home, as early as 1993 Australia recognised the need for what is now regarded as defence diplomacy activities in response to the changing international order. In the Strategic Review issued that year, the Australian Minster of Defence stated there was "an integral link between the defence of Australia and our increasing defence engagement with regional nations, the maintenance of our alliance relationships and our commitment to ensuring international peace and security." 28 As a harbinger of the dilemmas involved in defence diplomacy, the Australian approach attracted criticism for the tension between its policy of defence self-reliance and regional engagement. ${ }^{29}$ Other critics concluded

\footnotetext{
${ }^{24}$ Chairman of the Joint Chiefs of Staff, National Military Strategy of the United States of America: Shape, Respond, Prepare Now: A Military Strategy for a New Era (Washington D.C.: United States Joint Staff, 1997), 12.

${ }^{25}$ Department of the Army, US Army Field Manual 3-0, Operations (Washington D.C.: United States Army, 2001), 4-24.

${ }^{26}$ Chairman of the Joint Chiefs of Staff, National Military Strategy of the United States of America: Shape, Respond, Prepare Now: A Military Strategy for a New Era, 12.

${ }_{27}$ Thomas M. Jordan, Douglas C. Lovelace, and Thomas-Durell Young, "Shaping” the World through Engagement: Assessing the Department of Defense's Theater Engagement Planning Process (Carlisle, PA: Strategic Studies Institute, U.S. Army War College, 2000), 19-20.

${ }^{28}$ Australian Department of Defence, Strategic Review 1993 (Commonwealth of Australia, 1993), iii, http://www.defence.gov.au/oscdf/se/publications/stratreview/1993/1993_Part1.pdf.

${ }^{29}$ Fedor A. Mediansky, Australian Foreign Policy: Into the New Millenium (Melbourne, Australia: Macmillan, 1997), 88.
} 
that the two elements were simply contemporary versions of two long-standing components of Australian defence policy. ${ }^{30}$

From 1993 Australia increased its cooperative defence activities with Asia-Pacific countries, including conducting more exercises with members of the Association of South East Asian Nations (ASEAN) and establishing a number of bilateral defence arrangements with countries in the region, including the 1996 Lombok Treaty with Indonesia; a security pact whose aims included the promotion of cooperative activities. ${ }^{31}$

\section{Defence Diplomacy is born}

Thus, while a number of countries had engaged in a range of military cooperative and assistance activities for much of the 1990s, it was not until the end of that decade that the term defence diplomacy was first used during the UK Strategic Defence Review (SDR). Initiated in 1997, this review was the first comprehensive examination of defence policy conducted by the British government since 1993 and took account of developments in the post-Cold War world such as the burgeoning of international peace support operations. The SDR represented a reassessment of Britain's security interests and defence needs, and set out the roles, missions and capabilities of the UK armed forces to "meet these new realities." 32

In a departure from previous British defence policy, the SDR described a new role for defence in promoting understanding and trust between all European forces, and in particular assisting the development of modern democratic armed forces in central and Eastern Europe. ${ }^{33}$ One of the core Missions, which was termed Defence Diplomacy (hereafter captialised when referring to the UK military Mission), was developed to meet the Labour government's activist foreign policy in the new strategic environment. As stated in the SDR, the Defence Diplomacy Mission was intended to:

\footnotetext{
${ }^{30}$ Ibid.

${ }^{31}$ Rizal Sukma, "Indonesia's Bebas-Aktif Foreign Policy and the 'Security Agreement' with Australia," Australian Journal of International Affairs 51, no. 2 (1997): 235.

${ }^{32}$ United Kingdom Ministry of Defence, Defence Diplomacy, Policy Paper 1 (London: Director General Corporate Communication, 2000), 2.

${ }^{33}$ United Kingdom Ministry of Defence, Strategic Defence Review, July 1998, 12, http://webarchive.nationalarchives.gov.uk/20121026065214/www.mod.uk/NR/rdonlyres/65F3D7AC-43404119-93A2-20825848E50E/0/sdr1998_complete.pdf.
} 
...provide forces to meet the varied activities undertaken by the Ministry of Defence to dispel hostility build and maintain trust and assist in the development of democratically accountable armed forces, thereby making a significant contribution to conflict prevention and resolution. ${ }^{34}$

To help explain the concept, the UK Ministry of Defence (MoD) issued a specific supplementary paper on Defence Diplomacy as part of the SDR. In it, the Ministry acknowledged that while the idea of defence diplomacy was not new, there was greater scope for doing more to help prevent conflicts escalating or occurring in the first place. The Defence Diplomacy Mission would be the military's contribution to this objective. ${ }^{35}$ The use of the word 'diplomacy' reflected the way in which these activities conducted by armed forces contributed to foreign policy. As expressed in the SDR, "We require armed forces which can operate in support of diplomacy alongside economic, trade and development levers, to strengthen security and avert conflict." 36

The term defence diplomacy was reportedly coined by Secretary for Defence George Robertson, ${ }^{37}$ who injected it into the Ministry's review process. When introducing Defence Diplomacy in the supporting paper, Robertson described it in almost spiritual terms as "disarmament of the mind." While he may have coined the concept, ${ }^{38}$ it seems likely that the idea grew out of (or was given further impetus by) comments received during the review process that identified a need for more preventive diplomacy (diplomatic action taken to prevent disputes from escalating into conflicts and to limit the spread of conflicts when they occur ${ }^{39}$ ), including the use of aid to encourage economic and political development. Some participants in the review process believed that it would be a wise investment to shift a proportion of British defence resources into aid and conflict prevention. $^{40}$ Other submitters called for the conditional management of aid,

\footnotetext{
${ }^{34}$ United Kingdom Ministry of Defence, Strategic Defence Review Supporting Essay Four: Defence Diplomacy, 1998, 106.

35 Ibid.

${ }^{36}$ United Kingdom Ministry of Defence, Strategic Defence Review, 18.

${ }^{37}$ Robert F. Grattan, Strategic Review: The Process of Strategy Formulation in Complex Organisations (Farnham, UK: Gower Publishing, Ltd., 2011), 101.

${ }^{38}$ United Kingdom Ministry of Defence, "Strategic Defence Review Seminar - 5 November 1997 Summary of Opening Remarks by George Robertson MP, Secretary of State for Defence," November 5, 1997, http://web.archive.org/web/20000302155910/http://www.mod.uk/policy/sdr/sem1197.htm.

${ }^{39}$ David Capie and Paul Evans, The Asia Pacific Securty Lexicon, 2nd ed. (Singapore: Institute of Southeast Asian Studies, 2007), 185.

${ }^{40}$ United Kingdom Ministry of Defence, "Strategic Defence Review: Summaries of Seminars Held on 3 and 11 July 1997," accessed August 18, 2011, http://web.archive.org/web/19980701120134/http://www.mod.uk/policy/sdr/sem0797.htm.
} 
offers of training, assistance to civil structures and trade controls, as well as the need to ensure that ethical aspects of foreign policy were not just seen as negative options, such as the imposition of embargoes, but that positive steps by the military were considered that could be taken with others "in making a better world.",41

In the SDR, Defence Diplomacy was made into one of the eight core missions of Britain's armed forces in order to provide impetus, to signal its importance, and to ensure it was properly linked to wider Government policy objectives. Under the British taxonomy, Defence Diplomacy did not include multinational defence cooperation, which was included as a separate Mission. 'Outreach' activities and various military assistance programmes were all described as largely bilateral activities. ${ }^{42}$ The only area in which multilateral defence cooperation was employed as part of Defence Diplomacy was in the realm of arms control. As defined by the UK Ministry of Defence, Defence Diplomacy covered the range of activities outlined in Table 1 below.

\section{Table 1: United Kingdom Defence Diplomacy Activities ${ }^{43}$}

\begin{tabular}{|l|l|}
\hline 1. & $\begin{array}{l}\text { Ministry of Defence training courses and education programmes, including opportunities } \\
\text { for overseas students to attend courses at our military training establishments. }\end{array}$ \\
\hline 2. & $\begin{array}{l}\text { Provision of Loan Service Personnel, Short Term Training Teams, and civilian and } \\
\text { military advisers to overseas governments for extended periods. }\end{array}$ \\
\hline 3. & Visits by ships, aircraft and other military units. \\
\hline 4. & Inward and outward visits by Ministers and by military and civilian personnel at all levels. \\
\hline 5. & Staff talks, ${ }^{44}$ conferences and seminars to improve mutual understanding. \\
\hline 6. & Exchanges of civilian and military personnel. \\
\hline 7. & Exercises. \\
\hline
\end{tabular}

In terms of structure, sixteen specific Military Tasks were drawn from the eight core Missions set out in the SDR, which then formed the basis for identifying the force structures required by the British armed forces. ${ }^{45}$ The Defence Diplomacy Mission

\footnotetext{
${ }^{41}$ Ibid.

${ }^{42}$ United Kingdom Ministry of Defence, Defence Diplomacy, 7.

${ }^{43}$ Ibid., 4.

${ }^{44}$ Staff talks are systematic formal ongoing exchanges between headquarters' staff.

${ }^{45}$ United Kingdom Ministry of Defence, Strategic Defence Review, 18.
} 
consisted of three specific Military Tasks. The first was arms control, non-proliferation and confidence and security building measures; the second was 'outreach' activities specifically designed to contribute to security and stability in eastern Europe and the former Soviet Union through bilateral assistance and cooperation programmes; and the last covered those military assistance programmes with overseas military forces and defence communities not covered under 'outreach' activities. ${ }^{46}$ A range of other activities undertaken by the UK defence establishment including providing education scholarships and linkages to academia in foreign countries were also regarded as underpinning the defence diplomacy mission. In terms of its geographical focus, British Defence Diplomacy looked primarily at erstwhile adversaries in the Commonwealth of Independent States and former Warsaw Pact.

In summary, the UK policy of Defence Diplomacy represented a recognition and normalisation of developments over the previous decade in which the UK armed forces were being employed to assist the reform of the militaries of former Eastern bloc states in line with the political reform of their governments. Two key developments in the international security environment would each have an impact on the purposes for and the manner in which Defence Diplomacy was employed; these were the 11 September 2001 terrorist attacks, and the subsequent invasion of Iraq and its aftermath.

\section{Britain's Defence Diplomacy after September 2001}

It might have been expected that The War on Terror may have led to a shift back to 'old' patterns of defence diplomacy, focused on supporting authoritarian regimes and training their forces in counter-terrorist and counter-insurgency techniques. However, the opposite was the case, and the September 11 terrorist attacks spurred a resurgence in defence diplomacy activity, which saw terrorism as another form of conflict that could be prevented through military engagement activities.

In line with this thinking, the UK MoD revisited Defence Diplomacy as part of its new look at the 1998 SDR. The result of this mid-point review, named the 'New Chapter', highlighted the importance of Defence Diplomacy in addressing the causes of conflict and terrorism, as well as the benefits deriving from its broad-based approach. This was in

\footnotetext{
${ }^{46}$ Ibid., 20.
} 
contrast to the expectation that Western states would turn a blind eye to poor civilmilitary relations in the interests of stability in the post-911 world. ${ }^{47}$ There did not seem to be any element of conditionality introduced, whereby defence diplomacy was tied to issues such as human rights or recipients needed to demonstrate progress towards democratically accountable armed forces.

The post-9/11 reformulation of the SDR gave higher priority to the potential demands of counter-terrorism operations than the UK MoD ever did before, including the potential for particular countries to be partners in and to provide support to the War on Terror. As part of this role, Defence Diplomacy was attractive because of its perceived large area of engagement, high degree of influence and low cost. ${ }^{48}$ One new objective of Defence Diplomacy identified in the New Chapter was the lofty goal of helping "less capable states build a society in which terrorism is less likely to emerge."49 There was, however, tension and competition between the objectives of defence diplomacy as a means of promoting good civil-military relations and other issues such as assisting authoritarian regimes in countering terrorism. ${ }^{50}$

Ongoing operations in Afghanistan and the invasion and subsequent occupation of Iraq provided another watershed in the UK's thinking about Defence Diplomacy. In 2003, the UK MoD released a new Defence White Paper, Delivering Security in a Changing World. Most notably, this White Paper described non-operational international engagements conducted in support of the country's long-term foreign, defence and security policy objectives by using the term 'Defence Relations.' ${ }^{51}$ It explained that Defence Relations was a broader concept than Defence Diplomacy, and the adoption of Defence Relations resulted from the evolution in understanding and application of Defence Diplomacy since 1998.

\footnotetext{
${ }^{47}$ Cottey and Forster, Reshaping Defence Diplomacy, 32.

${ }^{48}$ United Kingdom Ministry of Defence, The Strategic Defence Review: A New Chapter. Supporting Information and Analysis, vol. II (Norwich: United Kingdom The Stationery Office, 2002), 19.

${ }^{49}$ United Kingdom Ministry of Defence, The Strategic Defence Review: A New Chapter (Norwich: United Kingdom The Stationery Office, 2002), 10, http://merln.ndu.edu/whitepapers/UK_SDR_2002.pdf.

${ }^{50}$ Cottey and Forster, Reshaping Defence Diplomacy, 32.

${ }^{51}$ United Kingdom Ministry of Defence, Delivering Security in a Changing World: Defence White Paper 2003 (Norwich: The Stationery Office, 2003), 8.
} 
The UK's most recent 2010 Strategic Defence and Security Review (SDSR) retained the focus on foreign policy-led defence activities, but interestingly no longer made mention of Defence Diplomacy. While the term certainly continued to be used leading up to the review, ${ }^{52}$ it was not referred to in the final document. Following the SDSR, UK Ministry of Defence prepared a Defence Engagement Strategy. In this strategy, 'Defence Engagement' was defined as 'the means by which we use our defence assets and activities to achieve influence internationally. ${ }^{53}$ Most notably, defence diplomacy in the British context reverted to its traditional definition, revolving around training and support to allied armed forces, and conducted in the context of providing support to contemporary operations. With the advent of 'Defence Relations' and later 'Defence Engagement', the term Defence Diplomacy in official UK defence policy as the prevailing means to describe relations with the armed forces of former and potential foes has disappeared. At the same time that the concept of Defence Diplomacy was being downgraded by its creators however, it was gaining in popularity elsewhere across the globe.

\section{Wider adoption of the concept}

The first country to adopt the term defence diplomacy in its official defence policy after the UK was Canada, which outlined its approach in a Defence Policy Statement which sat within the 2005 International Policy Statement. This document was designed to mark the beginning of a new and proactive whole of government engagement in international security and foreign relations. The Canadians described defence diplomacy (which, as in the UK SDSR, was coupled with another concept which they labelled forward presence) as an important part of defence efforts to contribute to international stability and outlined it in the Canadian context as consisting of a range of both high-profile and less visible tools for building relationships and shaping the international environment. ${ }^{54}$ These included bilateral and multilateral contacts, including staff talks, ship and aircraft visits, and participation in exercises. The purposes of Canadian defence diplomacy were described as helping Canada understand international security issues, enhancing

\footnotetext{
52 Royal United Services Association, "Nick Harvey MP Delivers Keynote Address," RUSI Analysis, July 7, 2010, http://www.rusi.org/analysis/commentary/ref:C4C3469BA71A88/.

${ }^{53}$ United Kingdom Ministry of Defence, Defence Engagement Paper (Draft) (London: Ministry of Defence, 2012), 1.

${ }^{54}$ Canada Department of National Defense, "Defence Policy Statement," in Canada's International Policy Statement: a Role of Pride and Influence in the World (Ottawa: Government of Canada, 2005), 28.
} 
democracy and civilian control and accountability of other armed forces. ${ }^{55}$ The Defence Policy Statement also identified that the defence relationships made with other countries, such as those in the Middle East particularly, assisted in the conduct of Canadian overseas military operations.

Looking further afield, other countries where the term became popular included India, who used the term to describe a range of activities from their confidence-building exercises with members of ASEAN to their strategic engagement with Viet Nam, ${ }^{56}$ and Indonesia, whose defence department embraced the term in the mid-2000s. ${ }^{57}$ Singapore began using the term as early as 2000 , when discussing bilateral relations with friendly countries and multilateral relations with a wider set of countries and institutions aimed at broader foreign policy goals such as "regional and global peace and stability.",58

The New Zealand defence establishment and various commentators began using the term defence diplomacy from 2000, directly influenced by the UK SDR. The way in which New Zealand has adopted the concept is the subject of the next Chapter.

\section{Debates and critiques}

One of the initial critiques of Defence Diplomacy came from the International Institute for Strategic Studies (IISS), which focused on issues around the engagement of states in central and eastern Europe by NATO members. ${ }^{59}$ It criticised the link made between Defence Diplomacy and NATO membership aspirations, the 'military tourism' aspect of defence personnel exchanges, the high cost of defence restructuring imposed on central and eastern European states (particularly at a time when these countries had many competing economic and social priorities), and the narrow focus on armed forces and state organs. This critique concluded that unless the concept of Defence Diplomacy was rethought to address these issues, defence diplomacy would more likely become a source of tensions both within NATO and between NATO and states in central and eastern

\footnotetext{
55 Ibid.

${ }^{56}$ Pankaj Kumar Jha, "India's Defence Diplomacy in Southeast Asia," Journal of Defence Studies, Institute for Defence Studies and Analyses 5, no. 1 (January 2011): 49-56. 49-56.

${ }^{57}$ Parulian Simamora, "The Current Status of Indonesia's Defence Diplomacy" (presented at the The Current Status of Defence Diplomacy Workshop. Lesperssi Seminar, Jakarta, November 28, 2007).

${ }^{58}$ Singapore Ministry of Defence, Defending Singapore in the 21st Century (Singapore: Singapore Government, 2000), 17.

${ }^{59}$ Bearman, "New Challenges to Defence Diplomacy," 41.
} 
Europe, and that its role as part of NATO policy would decline. Such criticism from the IISS, particularly about military tourism, is significant in light of that fact it was the IISS that established the Asia Security Summit, more commonly known as the Shangri-La Dialogue, soon afterward in 2002. For some time, the Shangri-La Dialogue was the preeminent regular gathering of Asia-Pacific defence ministers and their civilian and military chiefs of staff. ${ }^{60}$

Like the IISS, Henry Zipper de Fabiani argued that Defence Diplomacy would entail considerable political, social and economic implications for the nations of the former Eastern bloc, in terms of the conversion, modernisation and implementation of democratic control of armed forces. Writing in 2002, Fabiani provided a European perspective on Defence Diplomacy and its suitability for application by France. ${ }^{61}$ While he agreed that the UK and France shared a common goal and approach to the use of the military in support of foreign policy and security objectives of stabilisation and conflict prevention, his analysis pointed out the differing focus both in terms of priorities and geography, that is, on training and development of regional peacekeeping capabilities within Francophone Africa. This he summed up as "Nord-Sud du point de vue français, Est-Ouest du point de vue britannique." ${ }^{\prime 2}$ His statement highlighted the fact that Defence Diplomacy activities were likely to have different purposes and different priorities and these would vary from country to country. In terms of the concept itself though, he questioned the assumption that there was a worldwide single military culture, given the many fine details that differentiate military cultures and that link some militaries more than others. His point is significant, as one of the means in which defence diplomacy is often thought to be effective is because of the shared profession of arms that link military personnel from very different backgrounds. Fabiani questioned how suitable the concept was for France, but concluded that "Mais l'expression "diplomatie de défense" est sans doute déjà ancrée dans nos esprits : dans ce cas, il faudra s'en accommoder."63

\footnotetext{
${ }^{60}$ David Capie and Brendan Taylor, "The Shangri-La Dialogue and the Institutionalization of Defence Diplomacy in Asia," The Pacific Review 23, no. 3 (2010): 373.

${ }^{61}$ Henry Zipper de Fabiani, "Diplomatie de Défense et Diplomatie Préventive Vers Une Nouvelle Symbiose entre Diplomatie et Défense - Centre Thucydide - analyse et recherche en relations internationales," Annuaire Francais des Relations Internationales 3 (2002), http://www.afri-ct.org/The-defence-diplomacymain?lang=fr.

62 "France looks from north to south, Britain looks from west to east."

63 "But the expression "defence diplomacy" is probably already embedded in our minds: in this case, it will be necessary to accommodate."
} 
Essentially he meant the term was already here and in use; and the French would just have to make allowances for it.

Alice Hills, an academic with a background in police cooperation and assistance in Africa, provided another critique of the concept. She concluded that defence diplomacy was an over-extension of every day military business and had little lasting potential. ${ }^{64}$ In some ways these concerns were mirrored by some defence commentators and by some within defence forces themselves who argued that it diverted the military from its core business of war fighting. ${ }^{65}$ Hill's criticisms though were based on the fact that the concept appeared to cobble together a number of existing and proven elements but with the added expectation as a core military activity integrated with the activities of other government departments. She also criticised the concept for its basis on an assumed link between defence, security and development.

Contrasting Hills' conclusion that defence diplomacy was an over-extension of military business was Nicholas Floyd, an Australian Army officer writing at the Lowy Institute, who argued for a military role as a 'force multiplier' for foreign policy. ${ }^{66}$ Floyd contended that many contemporary foreign policy issues like climate change and terrorism were becoming security issues, and were falling within the realm of defence. In addition, in many cases the defence establishment was the only arm of government with the resources such as permanent planning staff to deploy personnel overseas at short notice. Floyd noted that other government departments which lack this capacity easily become reliant on the military and tied into military decision-making processes. Writing in a period in which diplomatic relations were rapidly expanding with a range of new countries, Floyd concluded that the military provided useful capacity to build these relationships if the diplomatic service lacks the resources to do so.

Proponents of the concept of defence diplomacy included Cottey and Forster, who have written probably the most comprehensive analysis of the concept to date. They saw that international military cooperation and assistance had been increasing and found that

\footnotetext{
${ }^{64}$ Hills, "Defence Diplomacy and Security Sector Reform," 64-65.

${ }^{65}$ Bearman, "New Challenges to Defence Diplomacy," 44.

${ }^{66}$ Nicholas Floyd, Dropping the Autopilot: Improving Australia's Defence Diplomacy, Policy Brief (Sydney: Lowy Institute for International Policy, 2010), 1, www.lowyinstitute.org/Publication.asp?pid=1459.
} 
patterns of cooperation had changed. In their analysis, they pointed out that one of the limitations of defence diplomacy was its lack of utility as a means of confidence-building and improving political relations where there were real and substantive political differences between countries, such as issues over borders or territory or over wider questions such as the international norms underpinning relations between states. ${ }^{67}$ Examples they provided of where this is the case included relations between Western countries and both Russia and China, or between India and Pakistan.

While somewhat unavoidable, Cottey and Forster also identified that too great a focus on the military's role in defence diplomacy could be an issue. ${ }^{68}$ They explained the risk that the pursuit of military cooperation activities would ignore other dimensions of good civilmilitary relations, such as the need for parliamentary oversight and engagement with civil society. As Chapter Six demonstrates, this was a risk incurred by New Zealand in its historical defence links with Indonesia. Other literature has focussed on a darker side to defence diplomacy, that of the 'militarisation' of foreign policy. The greatest concern here is that of 'institutional convergence;' its propensity to confuse the role of the military with that of other organs of the nation state; in this case, the diplomatic service and the conduct of public diplomacy. It was Nicholas Floyd again who pointed out that, in the absence of diplomatic resources, defence channels provided powerful alternative mechanisms for achieving international policy outcomes in support of the conventional Foreign Service. An op-ed piece in an Australian newspaper pointed out that:

...the military has become comparatively more important for the government as a tool for foreign relations. This is due primarily to the decline in usefulness of more traditional mechanisms such as foreign aid, diplomatic recognition and trade policy. ${ }^{69}$

According to Floyd, this could create tensions between defence and the group which had historically led in this context, the foreign service. ${ }^{70}$ For example, when considering Canadian participation in the Shangri-La Dialogue, the foreign ministry were wary of the defence department taking on a more prominent role in advancing Canada's regional

\footnotetext{
${ }^{67}$ Cottey and Forster, Reshaping Defence Diplomacy, 17.

${ }^{68}$ Ibid., 48.

${ }^{69}$ Athol Yates, "What Defence Really Does," Canberra Times, July 2, 2010, sec. Opinion, http://www.canberratimes.com.au/opinion/what-defence-really-does-20120701-21am5.html.

${ }^{70}$ Floyd, Dropping the Autopilot: Improving Australia's Defence Diplomacy. 10.
} 
engagement in Asia. As one account describes it "the Canadian foreign ministry didn't want the defence ministry stealing the limelight from them. ${ }^{, 71}$

To ameliorate such concerns, another Australian academic, Daryl Morini, recommended a synergy of civil-military efforts to shape Australia's diplomatic strategy towards Asia. One of his policy prescriptions specifically included greater intra-regional military diplomacy, perhaps modelled on the NATO Partnership for Peace initiative. ${ }^{72}$ Specific measures suggested by Morini included the establishment of a multinational military training facility, military observer mechanisms and military exchange programmes. He also suggested adopting NATO's approach to preventative diplomacy and conflict prevention in Eastern Europe for use in Asia. Morini warned that as these processes take place, the civilian agencies, particularly the diplomatic service, will become militarised in nature.

The IISS also criticised defence diplomacy for institutional convergence. This criticism often arose where armed forces discuss their role in conflict prevention. The IISS thought this was regarded negatively, particularly within military establishments, as distracting the military from its core role of war fighting, thus diminishing their capacity to fight wars. $^{73}$ A related issue was the difficulty in reconciling an armed force's primary task to defend the nation, with building sustainable defence cooperation with potential adversaries. The requirement to plan and prepare for warfare with such a potential adversary places an obstacle in the way of the successful use of defence diplomacy.

Fabiani foresaw the development of military appreciation amongst diplomats on one hand and greater diplomatic skills amongst soldiers on the other. ${ }^{74}$ In a paper explaining the role of Defence Attachés, the Geneva Centre for the Democratic Control of Armed Forces defined the main feature of defence diplomacy as "the combined use of diplomatic and military tools." 75 The question remained though whether it should be the diplomats who

\footnotetext{
${ }^{71}$ Capie and Taylor, "The Shangri-La Dialogue and the Institutionalization of Defence Diplomacy in Asia," 7.

${ }^{72}$ Darryl Morini, "Paradigm Shift: China's Rise and the Limits of Realism," Security Challenges 7, no. 1 (Autumn 2011): 105.

${ }_{73}^{73}$ Bearman, "New Challenges to Defence Diplomacy," 44.

${ }^{74}$ Zipper de Fabiani, "Diplomatie de Défense et Diplomatie Préventive Vers Une Nouvelle Symbiose entre Diplomatie et Défense - Centre Thucydide - analyse et recherche en relations internationales."

${ }^{75}$ Law (Editor), "Defence Attachés," 2.
} 
decide the focus and amount of defence effort expended in which countries, or should it be the military who decides? We will return to this question of which institution should take the primary role later in the thesis.

\section{Conclusion}

Peaceful relations between armed forces have been common and date back beyond the beginnings of the modern nation state itself. Cooperative interactions forces have tended to take place within the context of national friendships or alliances, and centred on improving the military capabilities of allies and the capacity to operate alongside them in the event of hostilities with other countries.

The post-Cold War period and the broadening security environment resulted in the recognition that defence cooperation was being increasingly employed, and in particular saw the emergence of 'new' defence diplomacy. The activities that comprised defence cooperation were not new, such as appointing defence attachés and conducting combined exercises, rather it was the changed nature and purposes to which it was being put; its chief characteristic being the extension of defence cooperation to the armed forces of former and potential adversaries.

Although these activities had been taken place for some time, it was the United Kingdom that gave defence diplomacy prominence as part of defence policy and established a framework of key tasks and purposes around it. Although the UK was the first to formally coin the term defence diplomacy, the concept itself had already been practised by other Western allies under different names. Despite the term falling out of favour with the British by 2010, Cottey and Forster's argument that defence diplomacy was "a genuinely new and significant development with some lasting relevance" ${ }^{, 76}$ has proven valid. Indeed, since its promulgation by the UK, the concept has been adopted by a widening range of countries including New Zealand. The NZDF both maintains longstanding traditional relationships with allies in Asia and has established new relationships with non-like-minded partners such as China, Viet Nam and India. New Zealand's defence diplomacy activities in Asia therefore provide a series of useful case studies that illustrate how the tensions and issues identified above have played out.

\footnotetext{
${ }^{76}$ Cottey and Forster, Reshaping Defence Diplomacy, 13.
} 
The way in which New Zealand has adopted the concept of defence diplomacy is the subject of the next chapter. It looks at the nature of New Zealand's 'old' defence diplomacy, using the example of the Five Power Defence Arrangements which have linked New Zealand to our chief allies in Asia - Singapore and Malaysia - since 1971. It will also introduce New Zealand's 'new' defence diplomacy in Asia together with its attendant issues and dilemmas. These will be explored in further detail in the subsequent case studies. 


\section{Chapter Three New Zealand's Defence Diplomacy in Asia}

\section{Introduction}

In order to explore New Zealand's conduct of defence diplomacy and discuss the issues and tensions it posed from a New Zealand perspective, this chapter begins by looking at the origins of New Zealand's usage of the term and employment of the concept. It then looks at traditional forms of New Zealand defence diplomacy, exemplified by the Five Power Defence Arrangements (FPDA). To contrast New Zealand's experience in traditional defence relationships with the 'new' defence diplomacy, it is necessary to look at the development of defence relations with countries that are "neither staunch friends nor confirmed foes." 77 The last section introduces the three case studies that will explore these relationships and their attendant tensions in more detail.

\section{The origins of New Zealand defence diplomacy}

A close reading of defence policy documents, including successive Defence White Papers since the late 1970s, suggests little detailed discussion of defence diplomacy activities took place in New Zealand until the publication of the 2010 Defence White Paper. ${ }^{78}$

Writing in 1997, former New Zealand Army officer and defence analyst Jim Rolfe argued military relationships were "an important practical and symbolic definer of international linkages and of the ebb and flow of international friendships."79 This statement, made in relation to alliances and associated military relationships, also applies to the range of activities which we now understand as defence diplomacy. This was illustrated by the way in which New Zealand's defence relationships broadened to include states like Viet Nam and China.

In Rolfe's discussion on alternatives to military alliances for New Zealand (which was published around the time that New Zealand was only just establishing formal defence relations with China), he considered that "the armed forces can and should be used as a

\footnotetext{
${ }^{77}$ Shelton, "Shaping a Better World: Military Engagement in Peacetime," 7-8.

${ }^{78}$ New Zealand Ministry of Defence, Defence White Paper 2010 (Wellington, N.Z.: New Zealand Government, 2010).

${ }^{79}$ Jim Rolfe, New Zealand's Security: Alliances and Other Military Relationships, CSS Working Paper 10/97 (Wellington, N.Z: Centre for Strategic Studies, 1997), 3.
} 
tool of international diplomacy in networking and confidence-building." ${ }^{80}$ He argued that formal alliances were not necessary to forge genuine links between states to reduce uncertainty. Rather, military cooperation activities were an alternative instrument that could achieve the same ends. ${ }^{81}$ Rolfe went on to advocate for the development of New Zealand military links with all states in the Asia Pacific region including China, Japan and the ASEAN states, recommending that cooperation should begin with bilateral exchanges of ideas and concepts at the officials level, followed by individual exchanges and exercises. He saw military relations as one link in a web of political, economic and cultural relationships between New Zealand and the region, reducing the likelihood of conflict between countries and facilitating the formation of alliances in the event of an external threat. $^{82}$

The New Zealand defence review that resulted in the 1997 White Paper The Shape of New Zealand's Defence was undertaken concurrently with the UK Strategic Defence Review (SDR), and while the New Zealand White Paper tipped its hat to the SDR, the two papers did not reach the same conclusions. While the UK SDR looked towards new opportunities to employ the armed forces in a wider range of tasks in support of foreign and security policy, Australian academic and former defence official Stewart Woodman described New Zealand's policy as being "tied to a vanishing rationale." 83 The 1997 White Paper didn't go into listing the specific tasks of the NZDF, but spoke instead of New Zealand's broad security requirements. These centred on "militarily effective capabilities" that were interoperable with allies and friends, that fulfil New Zealand's commitments under the FPDA, that contribute to regional security, to collective security efforts and peace support and humanitarian relief operations. ${ }^{84}$ There was no mention made in the 1997 White Paper about relationships with any other states outside the parameters listed above.

It was not until the 1999 report issued by the Foreign Affairs Defence and Trade Committee, entitled Inquiry into Defence Beyond 2000, that the wider role of defence in

\footnotetext{
${ }^{80}$ Ibid., 25.

81 Ibid.

${ }^{82}$ Ibid., 26.

${ }^{83}$ Stewart Woodman, "Back to the Future," New Zealand International Review 23, no. 2 (March 1998): 25.

${ }^{84}$ New Zealand Ministry of Defence, The Shape of New Zealand's Defence: a White Paper (Wellington, N.Z.: New Zealand Government, 1997), 24-25.
} 
New Zealand's international relations was discussed. ${ }^{85}$ Significantly, this report acknowledged that it had been informed by the 1997 UK Strategic Defence Review, and it elaborated a more expansive concept of security operations. The Committee recognised that:

There are many situations in which the NZDF can be used and is being used in non-combat roles to help promote an international environment where civil, political, economic, social and cultural rights can be more fully exercised. This involvement is an important way of demonstrating that New Zealand is a good international citizen and a good neighbour in the South Pacific. Of particular value in relation to advancing New Zealand's wider interests is the extensive network of contacts built up by the armed services in the Asia-Pacific region and beyond. We see more value in using the NZDF to support our wider international interests now, rather than in leaving it to concentrate on training and exercising for the more remote scenarios of an uncertain future. ${ }^{86}$

This clearly favoured the employment of the NZDF in promoting democratic civilian control of armed forces. The term 'defence diplomacy' was used in the minority members section of the Inquiry report, but they downplayed the concept in favour of more traditional applications of defence relationships:

Whilst acknowledging the value of defence diplomacy, Government members view NZDF personnel and assets as visible signs of the nation's willingness and commitment to assist in promoting stability in the Asia Pacific region, and many times a year our ships, aircraft and personnel deploy on training and goodwill visits throughout the region. ${ }^{87}$

In a 1999 paper providing an independent review of the Inquiry into Defence Beyond 2000, David Dickens pointed out that reductions in the NZDF's military capacity would significantly damage New Zealand's broader bilateral (and not just defence) relationships. Dickens considered that such reductions, such as the disbanding of the air strike capability and the decision to not purchase a further two ANZAC frigates, would not only damage our relations with Australia and the United States, but would also send a signal to

\footnotetext{
${ }^{85}$ Derek Quigley, Inquiry into Defence Beyond 2000: Report of the Foreign Affairs, Defence and Trade Committee (Wellington, N.Z.: House of Representatives, 1999), 65.

${ }^{86}$ Ibid.

${ }^{87}$ Ibid., 117.
} 
the region that New Zealand did not take defence seriously, damaging our relationships with Britain, Singapore and Malaysia. ${ }^{88}$

However, the Inquiry into Defence Beyond 2000 was not official defence policy, and so the first official use of 'defence diplomacy' in a New Zealand context came in the first of what was supposed to be a series of NZDF Capability Reviews undertaken following the release of the Defence Policy Framework. The purpose of these reviews was to form a new basis for capability acquisition consistent with the direction of the Framework. Released in 2000, it did not mention defence diplomacy by name, but discussed the roles and tasks of the NZDF in the South Pacific and wider Asia Pacific region in the context of defence relations. Specifically it stated that the NZDF would:

- strengthen our relationships in the Pacific through our Mutual Assistance Programme (MAP), including providing defence assistance and Overseas Development Assistance delivery; ${ }^{89}$

- continue to participate in FPDA activities;

- build upon existing co-operative bilateral defence relations with Singapore, Malaysia, Thailand and the Philippines; and

- develop a broader-based defence dialogue with other nations in East Asia. $^{90}$

The New Zealand Defence Force Capability Reviews: Phase One - Land Forces and Sealift issued by the Ministry of Defence in 2000 devoted a section in its discussion of the NZDF's Operational Environment to defence diplomacy. It defined defence diplomacy as:

all the varied activities undertaken by the NZDF to promote peace and security through constructive engagement and confidence-building. Its aim is to dispel hostility, build and maintain trust, and assist in the development of democratically accountable armed forces, thereby making a significant contribution to conflict prevention and resolution. ${ }^{91}$

\footnotetext{
${ }^{88}$ David Dickens, Lessening the Desire for War: The ASEAN Regional Forum and Making of Asia Pacific Security, Working Paper 11/98 (Wellington: Centre for Strategic Studies, Victoria University of Wellington, 1998), 9, http://www.victoria.ac.nz/css/docs/working_papers/wp11.pdf.

${ }^{89}$ New Zealand Ministry of Defence, The Government's Defence Policy Framework (Wellington, N.Z.: New Zealand Government, 2000), 5. 
This definition paraphrases the definition out of the 1998 UK SDR. The explanation provided in the document went on to borrow George Robertson's phrase 'disarmament of the mind'. 92

Within the NZDF, the notion of using the armed forces in a cooperative role was gaining traction. In the 1999 Purchase Agreement which set out the NZDF's planned annual outputs, the long-standing Key Result Area pertaining to defence links with Australia was expanded to become "Maintain defence relations and demonstrate defence cooperation with regional countries." 93 The subsequent year, this description was replaced with "Defence Diplomacy" as one of the key priorities of the NZDF, which was described as "security relationships and international activities." In the NZDF's 2005 Output Plan however, defence diplomacy had disappeared, leaving the "management of international military relations" subsumed as a component within NZDF's output pertaining to "Development and Production of Military Policy.",95

The final piece of defence policy issued by the New Zealand government in the first decade of the 2000s was the Government Defence Statement: a modern, sustainable defence force matched to New Zealand's needs published in May 2001. Despite it being issued within three years of the publication of the UK SDR, and immediately following the Defence Policy Framework, the Government Defence Statement made no mention of defence diplomacy or any other iteration of military relations, other than in relation to the potential confidence-building role of the soon-to-be-disbanded air combat force. ${ }^{96}$

In the end it was not so much defence policy, but rather defence doctrine that first cemented the introduction of the term defence diplomacy into the New Zealand lexicon. Unlike policy, which identifies and articulates defence needs and interests and is potentially fluid and changeable, defence doctrine is more enduring and less subject to change and its purpose is to describe the methods for successfully conducting military

\footnotetext{
${ }^{92}$ Grattan, Strategic Review: The Process of Strategy Formulation in Complex Organisations, 116.

${ }^{93}$ New Zealand Defence Force, 1999/2000 Purchase Agreement Between Minister of Defence and Chief of Defence Force for Year Ending 30 June 2000 (Wellington, N.Z.: New Zealand Government, 1999), S1-4.

${ }^{94}$ New Zealand Defence Force, 2000/2001 Purchase Agreement Between Minister of Defence and Chief of Defence Force for Year Ending 30 June 2001 (Wellington, N.Z.: New Zealand Government, 2000), S1-4.

${ }^{95}$ New Zealand Defence Force, Output Plan 2005 for Year Ending 30 June 2006. (Wellington, N.Z.: New Zealand Government, 2005), S3-10.

${ }^{96}$ New Zealand Ministry of Defence, Government Defence Statement: a Modern, Sustainable Defence Force Matched to New Zealand's Needs (Wellington, N.Z.: New Zealand Government, 2001), 10.
} 
operations. ${ }^{97}$ Doctrine is significant as it provides the perspective of the armed forces on what defence diplomacy entails and the ends to which it is directed. The NZDF's capstone doctrine document, Foundations of New Zealand Defence Doctrine, first published in 2004 provided the following definition of defence diplomacy:

... activities (such as military visits, exchanges of military information, and the provision of military education and training) are intended to dispel hostility, build and maintain trust, and assist in the development of democratically accountable defence forces. ${ }^{98}$

Again, this was drawn from the British SDR definition. ${ }^{99}$ New Zealand doctrine regarded defence diplomacy as a conflict prevention activity and placed it in context as the military component of the diplomatic instrument of national power. Doctrine hinted that the military element is employed in direct support of civil objectives when it stated:

Diplomacy is enhanced by NZDF staff in embassies, the provision of operational military advice and assistance, the conduct of overseas training, and other influence activities. ${ }^{100}$

In 2007, Rolfe again returned to defence diplomacy, arguing the modernisation of the NZDF in the 2000s had delivered armed forces whose equipment and roles demonstrably met New Zealand national interests. In particular, he identified that the NZDF had become able to deliver an increasing array of options to the government, including practising defence diplomacy. ${ }^{101}$

By the mid-2000s, defence diplomacy had become one of the NZDF's key priorities; entailing visits, exchanges, consultations and deliberations on non-conventional and 'soft' threats as well as military matters. ${ }^{102}$ Like Rolfe, Stephen Hoadley identified that new NZDF capabilities, such as the Protector fleet for example, was evidence that engaging in

\footnotetext{
${ }^{97}$ New Zealand Defence Force, New Zealand Defence Doctrine Publication (NZDDP) - D Foundations of New Zealand Military Doctrine 2008 (Wellington, N.Z.: New Zealand Government, 2008), 1-1 - 1-2, http://www.nzdf.mil.nz/downloads/pdf/public-docs/2008/nzddp-d-2008-ed-2.pdf.

${ }^{98}$ New Zealand Defence Force, New Zealand Defence Doctrine Publication (NZDDP - D) Foundations of New Zealand Military Doctrine 2004 (Wellington, N.Z.: New Zealand Government, 2004), 8-3.

${ }^{99}$ Namely Joint Warfare Publication 0-01 - British Defence Doctrine, 6-2 - 6-3.

${ }^{100}$ New Zealand Defence Force, New Zealand Defence Doctrine Publication (NZDDP - D) Foundations of New Zealand Military Doctrine 2012 (Wellington, N.Z.: New Zealand Government, 2012), 5.

${ }^{101}$ Jim Rolfe, Cutting Their Cloth: New Zealand's Defence Strategy (Barton, Australia: Australian Strategic Policy Institute, 2007), 18.

102 Stephen Hoadley, "From Defence to Security: New Zealand's Hard Power, Soft Power, and Smart Power," New Zealand International Review 32, no. 5 (September 2007): 19.
} 
activities like defence diplomacy alongside their civilian and diplomatic counterparts would be an expanding part of the New Zealand navy's mission. ${ }^{103}$ This sentiment was echoed by the commanding officer of HMNZS Te Kaha when he explained to a reporter during a port call to China in 2007 that "most ports, we have what you call defence diplomacy. It's a melding of military and civil diplomacy. We will generally co-host a function with the embassy."104 Hoadley considered that soft power "was the sort of power a progressive small state like New Zealand can develop and deploy." "105 For a small nation in particular, rather than being a tool of coercion, the use of armed forces in defence diplomacy was a form of engagement which contributed to transparency and confidence-building. Defence diplomacy in the New Zealand context was a means to enhance regional security by engaging other nations, reinforce shared international norms, and amplify New Zealand's otherwise limited reach and influence.

Prior to the 2008 New Zealand parliamentary election, both main political parties undertook to carry out a defence review. In 2009, the new National Government began the first full review of defence policy in over ten years. The resulting Defence White Paper 2010 briefly examined the NZDF's contribution to international peace and security. It stated that:

"New Zealand will also contribute to regional and international peace and security by building various defence linkages. These can range from the assignment of defence attaches, through to formal military-to-military talks, and participation in bilateral and multilateral exercises." 106

The White Paper (and the preceding Defence Assessment 2010) set out a number of ways in which these defence linkages added value to New Zealand's contribution to international efforts to resolve conflict. These were described as building influence with security partners and friends so that our interests are taken into account; helping to keep us informed of security issues; providing professional development for the NZDF; enabling the NZDF to be well-informed about defence technology and military doctrinal

\footnotetext{
103 Ibid.

${ }^{104}$ Rebecca Palmer, "Flying the New Zealand Flag in China," Stuff Website, October 15, 2007, http://www.stuff.co.nz/national/17007/Flying-the-New-Zealand-flag-in-China.

${ }^{105}$ Hoadley, "From Defence to Security: New Zealand's Hard Power, Soft Power, and Smart Power," 19.

${ }^{106}$ New Zealand Ministry of Defence, Defence White Paper 2010, 40.
} 
developments; and adding engagement to our bilateral relationships, especially where partner countries place a particular value on defence relations. ${ }^{107}$

While the overall message of the 2010 White Paper was that New Zealand was keen to rekindle ties with traditional partners, ${ }^{108}$ it acknowledged the new form of defence diplomacy as defined by Cottey and Forster. Within three paragraphs under a subheading 'Support peace and security in the Asia-Pacific region' in Chapter Four, the 2010 White Paper specifically listed a number of defence and diplomatic activities that enabled New Zealand to uphold and contribute to the favourable environment engendered by a stable and prosperous Asia. Specific activities included developing good bilateral defence relations with other states, encouraging them to operate constructively in the region and exercising and training with regional armed forces. Notable is the geographic focus on Asia. It is evident that the rationale of these activities is conflict prevention, but there is a distinct lack of discussion about the role of defence relations in the development of democratically accountable defence forces.

Robert Ayson recognises the reluctance in the White Paper to discuss New Zealand's defence relationship with China, noting there is nothing at all in the declassified version of the Defence Assessment about it. ${ }^{109}$ This reluctance may have more to do with sensitivity about relations between the two countries rather than any particular absence of policy. But Ayson questioned whether the White Paper's failure to mention Indonesia, Fiji and Papua New Guinea demonstrated that New Zealand's defence diplomacy had little role to play in the region. ${ }^{110}$

While extant New Zealand defence policy acknowledged the purposes and means to conduct what was regarded as defence diplomacy without using the term itself, defence diplomacy has appeared in a number of subsequent official documents. The Terms of Reference signed annually between the Minister of Defence and the Chief of Defence Force, which set out the Chief of Defence's duties and obligations in delivering the Government's defence policy objectives, made explicit goals for defence diplomacy,

\footnotetext{
${ }^{107}$ Ibid., 40.

${ }^{108}$ Rod Lyon, The New Zealand Defence White Paper: a More Strategically-extroverted Kiwi?, Policy Analysis 69 (Barton A.C.T.: Australian Strategic Policy Institute, 2010), 1-2. 1-2.

${ }^{109}$ Robert Ayson, "Force and Statecraft: Strategic Objectives and Relationships in New Zealand's 2010

Defence White Paper," Security Challenges 7, no. 1 (Autumn 2011): 26.

${ }^{110}$ Ibid., 28.
} 
regional engagement and maintaining and strengthening the Defence Force's network of relationships with overseas partners. ${ }^{111}$ The NZDF's most recent Statement of Intent discussed 'military diplomacy' for the purposes of strategic shaping. ${ }^{112}$ The NZDF's Output Plans, which record the output delivery decisions agreed by the Minister of Defence with the Chief of the New Zealand Defence Force each financial year, describe defence diplomacy activities in terms of naval ship visits and support to the Ministry of Foreign Affairs and Trade. ${ }^{113}$ This suggested that the term was more in vogue with the operators or 'service delivery arm' of the Defence Force, rather than the policymakers in the Ministry of Defence.

It should be noted that the New Zealand Ministry of Foreign Affairs also recognised the expanding role of defence diplomacy in recent efforts towards closer security engagement. ${ }^{114}$ Interestingly, under the umbrella term 'security engagement' MFAT differentiated defence diplomacy from 'bilateral military ties' and multilateral arrangements such as the ASEAN Regional Forum and the Five Power Defence Arrangements in their Asia White Paper released in 2007. It is unclear quite how MFAT defined defence diplomacy in this case.

\section{New Zealand Defence Diplomacy Activities}

New Zealand's defence diplomacy encompasses a wide range of activities, few of which are new. The country conducts defence diplomacy through various means including the appointment of defence attachés, port calls, combined exercises, educational exchanges, high-level dialogues, and multilateral cooperation.

Table 2: New Zealand Defence Diplomacy Activities

\section{High-level ties}

Bilateral and multilateral contacts between senior military and civilian defence officials such as Closer Defence Relations (CDR) with Australia, the ASEAN Regional Forum

\footnotetext{
${ }^{111}$ Peter Coleman, "The Value of Defence Relationships," One Force no. 5 (October 2010), http://www.nzdf.mil.nz/news/publications/one-force/5/value-of-defence-relationships.htm.

${ }^{112}$ New Zealand Defence Force, The 2013-2016 Statement of Intent (Wellington, N.Z.: New Zealand Government, 2013), 21, www.budget.govt.nz/budget/pdfs/ise-v4/soi-nzdf-2013-16.pdf.

${ }^{113}$ See New Zealand Defence Force, "NZDF 2011/2012 Output Plan,” accessed March 7, 2012, http://www.parliament.nz/NR/rdonlyres/2B1C43CE-8BEC-4C6F-B060DA64F23A88F5/194774/49SCFDT_EVI_00DBSCH_EST_10656_1_A188393_StandardEs.pdf.

${ }^{114}$ New Zealand Ministry of Foreign Affairs and Trade, Our Future with Asia (Wellington, N.Z.: New Zealand Government, 2007), 59.
} 
(ARF), the ASEAN Defence Ministers Meeting Plus, the Five Power Defence Arrangements (FPDA).

\section{Military to military contacts}

Bilateral and multilateral contacts between senior military officials.

Army to Army Staff Talks.

Appointment of defence attaches to foreign countries.

Bilateral defence cooperation agreements.

Placement of military or civilian defence personnel in partner countries' defence ministries or armed forces.

\section{Military Training and Education}

Training of foreign military personnel such as at Command and Staff College.

New Zealand's Mutual Assistance Programme.

Deployment of training teams.

Development of peacekeeping capabilities.

\section{Exercises}

Bilateral or multilateral military exercises for training purposes.

\section{High-level ties}

High-level exchanges typically preceded the formalisation of defence links and were a regular feature of mature relationships. The institutionalisation of high-level exchanges into Strategic Dialogues tended to occur further along in the development of the relationship, but this was a key objective in terms of progressing defence links. Former Defence Minister Wayne Mapp described bilateral Strategic Dialogues as "really important" and very much what he described as macro-level defence diplomacy. ${ }^{115}$ Former Ambassador to China Tony Browne saw them as one component of a broad range of ties, pointing out:

...you need to put that dialogue into context. We've got 27 or 28 , or some colossal number of annual dialogues with China. We've got them on dairy, on forestry, on quarantine, on consular issues, trade; we've had a security dialogue conducted by the foreign ministries for a long time, many many years. We have Pacific talks. I once did the logistic count of how many of these dialogues there were and we've got almost as many formal dialogues of this sort as we do with Australia." 116

\footnotetext{
${ }^{115}$ Author's interview with Dr Wayne Mapp, 14 March 2013, n.d.

${ }^{116}$ Author's interview with Tony Browne, 11 March 2013, n.d.
} 


\section{Defence Attachés}

As discussed in Chapter Two, defence attachés were perhaps the earliest form of cooperative engagement between armed forces. Defence attachés were significant as their appointment represented the formalisation of defence links between countries and they provided the long-term as well as the day-to-day contact between militaries. ${ }^{117}$ Prior to 1991, New Zealand defence attachés were part of the former Ministry of External Relations and Trade. ${ }^{118}$ The manner in which the attaché worked and the perspective of the country they were posted to had an impact on the nature of the defence relationship. Each defence attaché's approach differed from post to post. For example, China wanted the New Zealand defence attaché to be the facilitator of high-level contacts rather than the conduit of that contact; the Chinese did not want the substantive contact to occur through the attaché. ${ }^{119}$ In addition, the first defence attaché posted to China saw himself as a member of the international attaché legation, and his priority lay with international engagement rather than national engagement. As a result, day-to-day contact between the attaché and the PLA was limited. This was in contrast to the approach of the defence attaché in Jakarta at the same time, who had excellent contacts within the Indonesian military. ${ }^{120}$ New Zealand's defence attaché network is reviewed approximately every ten years and within the last two years there has been renewed debate about the value and priority of the defence attaché network and where exactly New Zealand's efforts should be directed. ${ }^{121}$ This debate mirrored that which took place about New Zealand's wider diplomatic representation. ${ }^{122}$ Given the burgeoning of defence links since the 1990s, there has been increasing pressure on the attaché network. Discussions with a range of officials raised the point that more thought needs to be put into deciding where our efforts would deliver the most value. The regular reviews suggest that this decision is proving a difficult one.

\footnotetext{
${ }^{117}$ Kenneth W. Allen et al., China's Foreign Military Relations (Henry L. Stimson Center, 1999), 5.

${ }^{118}$ Evaluation Division, Review of Defence Attaches and Advisors, 20028 (Wellington, N.Z.: New Zealand Ministry of Defence, 2002), 7.

${ }_{119}$ Author's interview with Tony Browne, 11 March 2013.

${ }^{120}$ Author's interview with Chris Elder, 27 March 2013.

${ }^{121}$ Roderick Deane, Value for Money Review of New Zealand Defence Force (Wellington N.Z.: Pacific Road Group, 2010), 205-206.

${ }^{122}$ Murray McCully, "Speech to the New Zealand Institute of International Affairs," Speeches, April 5, 2011, http://www.beehive.govt.nz/speech/speech-new-zealand-institute-international-affairs-1.
} 


\section{Port calls}

Port calls remain the most obvious form of defence diplomacy activity, and are often the first thing cited when discussing defence links. ${ }^{123}$ Port calls have a long tradition, predating the 20th century, and are a sub-set of naval diplomacy which includes both cooperative and coercive forms. ${ }^{124}$ In its cooperative form, 'show the flag' tours have been a common use for Royal New Zealand Navy deployments throughout Asia. A single naval deployment to Asia is likely to involve a range of defence diplomacy activities including exercises with FPDA partners, patrols and visits to new partners like Indonesia, China and Viet Nam. As the numbers in Chapters Four to Six show, port calls are one of the primary means through which New Zealand conducts defence diplomacy. New partners also place a lot of weight on the symbolic importance of naval visits. ${ }^{125}$

\section{Training and education}

Training and education is a significant part of New Zealand's defence diplomacy. One of the primary vehicles to deliver this is the NZDF Command and Staff College. ${ }^{126}$ Offering places to officers of other countries provides some ability to influence the officer cadre of their armed forces. ${ }^{127}$ As the former Commandant of the College, Shaun Fogarty explained "Each year, approximately 30 percent of the New Zealand staff course was made up of international course members. ${ }^{128}$ Fogarty described the impact of this on defence relations with China, Viet Nam and Indonesia, saying "those relationships have really grown because of Staff College and defence diplomacy. Soft power is really what it is, it's a way of engaging without having major military exercises which confront people." Each course also conducted an international tour. Fogarty argued this was "a pretty powerful tool when you turn up with fifty people in someone's country and you engage at significantly high levels at times [...] it indicates you're taking a serious approach to engagement with them." ${ }^{129}$ NZDF officers also attend courses at overseas

\footnotetext{
${ }^{123}$ For example, see Prime Minister John Key's address 'A Strengthening China - New Zealand link', opening the China Symposium held in the Legislative Council Chamber, Parliament Buildings, Wellington on 5 September 2012.

${ }^{124}$ du Plessis, "Defence Diplomacy: Conceptual and Practical Dimensions with Specific Reference to South Africa," 94.

${ }^{125}$ Author's interview with Chris Elder, 27 March 2013.

${ }^{126}$ New Zealand Ministry of Foreign Affairs and Trade, "Republic of Singapore," Countries, August 3, 2012, http://www.mfat.govt.nz/Countries/Asia-South-and-Southeast/Singapore.php.

${ }^{127}$ B. S. Sachar, "Cooperation in Military Training as a Tool of Peacetime Military Diplomacy," Strategic Analysis 27, no. 3 (September 8, 2003): 410.

${ }^{128}$ New Zealand Ministry of Foreign Affairs and Trade, "Republic of Singapore."

${ }^{129}$ Author's interview with CDR Shaun Fogarty, 12 December 2012.
} 
defence colleges, which "contributes to strong relationships between New Zealand and the international community." "130 Furthermore, visits by foreign defence delegations "create engagement opportunities and generate good-will among the nations concerned and New Zealand."131 Training cooperation also provided benefits to NZDF personnel by improving their understanding of the armed forces of their foreign counterparts, and their language, culture and political systems. ${ }^{132}$

Another important instrument was the Mutual Assistance Programme (MAP), which is bilateral in nature. MAP's purpose is to complement efforts in the political, economic and development fields to encourage friendly and cooperative bilateral relationships with New Zealand's near neighbours. The Programme's Mission Statement explained:

The MAP Mission Statement is to contribute in practical terms to the achievement of the NZDF's mission to promote secure and stable neighbourhoods, through the provision of training, technical and other support to South Pacific and Southeast Asian security and defence forces. ${ }^{133}$

Participation in MAP activities was decided on an annual basis following advice from the Ministry of Defence's International Defence Relations Branch, discussed later in this chapter, on which countries are approved to participate. MAP provides technical assistance, training, and exchange opportunities to defence forces in South East Asia and the South Pacific. It originated in patterns of 'old' defence diplomacy; back to the NZDF's earlier involvement in South East Asia and the desire to assist with securing a stable environment for the political, social and economic development of New Zealand's security partners. The NZDF acknowledged the character of the Programme had moved beyond that of client/donor context and that South East Asian countries no longer required much of the basic training that NZDF provided in the past. Instead, the training sought by these countries was in areas where NZDF's professionalism was highly regarded. ${ }^{134}$ MAP provides training in New Zealand, but also deploys training teams to provide training in specific areas as requested. Based as it is on the principle of mutual

\footnotetext{
${ }^{130}$ New Zealand Ministry of Foreign Affairs and Trade, "Republic of Singapore."

131 Ibid.

${ }^{132}$ Sachar, "Cooperation in Military Training as a Tool of Peacetime Military Diplomacy," 410.

${ }^{133}$ New Zealand Defence Force, "Chapter One: Policy Framework," in DFO 67: Defence Force Orders for the Mutual Assistance Programme, 2005.

134 Ibid.
} 
assistance, partner countries under the MAP reciprocate by offering training to NZ as well.

\section{Exercises}

Military exercises complement training and education by providing a means to practice operational skills in a controlled setting and providing collective training (that is an unit level). Collective training occurs with other units, jointly with other Services, and combined with the armed forces of other countries. ${ }^{135}$ Exercises traditionally occurred for the purposes of preparing for undertaking the use of force. For example, Five Power Defence Arrangements exercises practised activities like air defence, anti-submarine warfare and Command Post exercises. More recently, and reflecting emerging security concerns, new exercises practise counter-terrorism and humanitarian assistance disaster relief operations.

The NZDF includes activities such as search and rescue, disaster relief and surveillance of Exclusive Economic Zones in the range of defence bilateral relationships. This is significant as these are operational activities that are not often regarded as part of defence diplomacy as defined by other countries. It should also be acknowledged that defence diplomacy is not viewed by the New Zealand as a substitute for defence spending on tangible military capabilities. ${ }^{136}$ It was rather seen as one of the means in which defence acts to prevent or deter conflict, and thus reduce the cost of delivering stability and security.

\section{New Zealand's 'old' Defence Diplomacy - The Five Power Defence Arrangements}

To help put 'new' defence diplomacy into perspective, it is necessary to discuss the nature of New Zealand's traditional defence relations or 'old' defence diplomacy. The difference between New Zealand's defence diplomacy with traditional allies, and engagement with the armed forces of non-like minded states will be further explored through the use of three case studies; China, Viet Nam and Indonesia.

Cottey and Forster characterised 'old' defence diplomacy as part of international realpolitik, balance-of-power politics and the pursuit of narrowly-defined national

\footnotetext{
${ }^{135}$ New Zealand Ministry of Foreign Affairs and Trade, "Republic of Singapore."

${ }^{136}$ Author's interview with Gerald Hensley, 22 March 2013, n.d.
} 
interests. ${ }^{137}$ Defence cooperation and military assistance was provided to other states in order to counterbalance or deter enemies, maintain spheres of influence, support friendly regimes in suppressing domestic opponents or promote commercial interests. ${ }^{138}$ New Zealand's security assistance was historically directed to states in South East Asia on the front line of the Cold War. In Asia, its closest defence and security partners were, and continue to be, Singapore and Malaysia. In fact, both the NZDF and MFAT regarded the defence relationship with Singapore as the second most active after Australia. ${ }^{139}$ Malaysia was not far behind. For this reason, New Zealand's involvement in the FPDA provides the prime example of New Zealand's 'old' defence diplomacy in action.

As Cottey and Forster point out, many former British colonies chose to maintain extensive defence links to their former colonial power. The FPDA grew out of the defence links Britain developed with the members of its Empire in the Asia Pacific. It was established as part of Britain's withdrawal 'East of Suez', and withdrawal out of major military bases in Malaysia and Singapore and its commitments to the 1957 AngloMalaysian Defence Agreement. It brought together three external powers (the United Kingdom, Australia and New Zealand) to guarantee the security of Singapore and Malaysia, mainly in the face of Communist aggression advancing through Indochina, but also Indonesia's 'Confrontation' policy.

When it was established in 1971, the FPDA had a specific security focus and acted as a loose military alliance. ${ }^{140}$ In the first ten years there was little institutional activity, and there were few ongoing exercises. Invigorated by the 1979 Vietnamese invasion of Cambodia and the invasion of Afghanistan, a regular series of significant exercises were begun in the early 1980s. ${ }^{141}$ By the 1990s combined and joint exercises took place in which land and naval forces played a greater role with air forces. ${ }^{142}$

\footnotetext{
${ }^{137}$ Cottey and Forster, Reshaping Defence Diplomacy, 7.

${ }^{138}$ Ibid.

${ }^{139}$ New Zealand Defence Force, Briefing to the Incoming Government 2005 (Wellington N.Z.: New Zealand Government, 2005), 13, www.nzdf.mil.nz/downloads/pdf/public-docs/nzdf-bim-2005.pdf; New Zealand Ministry of Foreign Affairs and Trade, "Republic of Singapore."

${ }^{140} \mathrm{Jim}$ Rolfe, Anachronistic Past or Positive Future: New Zealand and the Five Power Defence Arrangements, CSS Working Paper 4/95 (Wellington N.Z.: Centre for Strategic Studies, 1995), 7. ${ }^{141}$ Ibid., 8.

${ }^{142}$ Carlyle A. Thayer, "The Five Power Defence Arrangements Exercises and Their Contribution to Regional Security, 2004-2010" (presented at the Conference on the Five Power Arrangements at Forty, Traders Hotel, Singapore: S. Rajaratnam School of International Studies, 2011), 3.
} 
Up until the mid to late 1990s the FPDA only played a peripheral role in New Zealand's defence thinking; the bulk of attention prior to that was on defence relationships with the United States and Australia. ${ }^{143}$ The NZDF recently described the FPDA as "our primary element in defence cooperation and engagement in South East Asia." ${ }^{144}$ What has explained this change, and what were the implications for New Zealand's defence diplomacy?

First, the strategic situation has changed since the Arrangements were established. The UK, Australia and New Zealand were originally the dominant military forces in FPDA, in both equipment and training. Now however, Singapore and Malaysia have highly capable military forces, equipped with a range of modern platforms straight from US, Russian and most tellingly, their own indigenous inventories, and they have the means and capacity to defend themselves. The Singapore military is considered to be the most capable in South East Asia. ${ }^{145}$ In terms of the wider security environment within the region, in 1971 ASEAN was made up of five members, but it is now a well-established and comprehensive regional community, amongst which there is no expectation that disputes will be resolved with force. ${ }^{146}$ Carlyle Thayer argues that the FPDA had become "the quiet achiever" and an important component among the multitude of multilateral structures making up South East Asia's security architecture. ${ }^{147}$ The key to the FPDA's longevity was that it adapted over time to provide different benefits to each of the participants. Since the end of the Cold War it had become a networking and confidencebuilding arrangement for its own region.

The FPDA also illustrates the way in which debates over who should lead between the foreign service and the defence establishments can potentially complicate defence relationships. Throughout much of the early history of the FPDA, the New Zealand Ministry of Foreign Affairs and Trade (MFAT) took the view that the FPDA was irrelevant; a transitional measure that had passed its usefulness. ${ }^{148}$ When the series of

\footnotetext{
${ }^{143}$ Rolfe, New Zealand's Security, 3.

${ }^{144}$ New Zealand Defence Force, New Zealand Defence Force Annual Report 2011 (Wellington: New Zealand Government, 2011), 6.

${ }^{145}$ Department of Defence, Defence 2000: Our Future Defence Force, Parliamentary Paper 451 (Canberra: Defence Publishing Service, 2000), 40.

146 Rolfe, Anachronistic Past or Positive Future, 3.

147 Carlyle A. Thayer, "The Five Power Defence Arrangements: The Quiet Achiever," Security Challenges 3, no. 1 (February 2007): 80.

${ }^{148}$ Rolfe, Anachronistic Past or Positive Future, 8.
} 
significant exercises began in the 1980s, MFAT was of the view that the FPDA had little strategic relevance and was of questionable value. ${ }^{149}$ At the time, MFAT was at pains to present these exercises as a continuation, rather than a new development or revitalisation of FPDA, presumably mindful of their perception by other countries in the region. Rolfe pointed out that Defence, on the other hand, valued the networking and training aspects of the relationship and since this time "the FPDA has been transformed into an active set of military networking and operational relationships from which all participants value." 150 Gerald Hensley, the former Secretary of Defence recalls that “...after 1989, [...] there was more reason than ever for us to put policy weight on the FPDA and its exercises, because it was a remaining sign of our interest and commitment."151

For the NZDF, the FPDA also offered an alternative forum for professional military exchanges after the opportunity to train with United States forces was lost following the break in the ANZUS alliance. ${ }^{152}$ This change in perception was summed up by Prime Minister Helen Clark who said "We will maintain full participation in the FPDA because we believe that it is helpful for armed forces' training and preparedness, and that the agreement plays an important part in Malaysia-Singapore relations." ${ }^{153}$ A MFAT submission to a NZDF Maritime Patrol review in 2000 even went so far as to state "a reduced role for New Zealand in the FPDA would reduce our standing within the FPDA and with the region in general.",154

At present, NZDF participation in FPDA exercises include hosting FPDA contingents on exercises like the annual Singapore artillery exercise and conducting combined naval and air force exercises in Malaysia and Singapore. There has also been discussion about hosting the Singapore Air Force for exercises at Ohakea. ${ }^{155}$ The defence relationship has also broadened. A senior MFAT official described how New Zealand's relationship with Singapore and Malaysia through FPDA was credited with assisting their contribution to

\footnotetext{
${ }^{149}$ Rolfe, Anachronistic Past or Positive Future.

${ }^{150}$ Ibid., 8.

151 Author's interview with Gerald Hensley, 22 March 2013.

152 Ibid.

${ }^{153}$ New Zealand Ministry of Foreign Affairs and Trade, "Review of Maritime Patrol: MFAT Submission" (Department of Prime Minister and Cabinet, November 2000), 59.

154 Ibid., 60.

155 Jimmy Ellingham, "Pilot Training Tipped for Ohakea," Manawatu Standard, January 8, 2010, http://www.stuff.co.nz/manawatu-standard/news/3215019/Pilot-training-tipped-for-Ohakea.
} 
the United Nations missions in East Timor and later the International Security Assistance Force mission in Afghanistan:

The relationship, that people-to-people relationship, that's been established through FPDA has enabled it to move into relevant areas of operation; to look at opportunities where we can work alongside each other on a place like Afghanistan because we have that experience working alongside each other in FPDA. [...] ...it's that confidence in the relationship with New Zealand that has encouraged them... ${ }^{156}$

Looking towards the future, the NZDF wishes to encourage more engagement with Singapore in multilateral forums, but it should also be noted there are also strong bilateral defence links between New Zealand, Singapore and Malaysia. For some time, both countries participated in MAP until Singapore withdrew in 2008 owing to its progress. There is a New Zealand-Singapore Strategic Dialogue which is managed by the Ministry of Defence's International Defence Relations Branch. A Singapore - New Zealand Defence Coordination Group was established in 1995, and the Malaysian equivalent established in 1996, in which senior defence officials oversee the future direction of each relationship. They discuss policy issues relating to bilateral cooperation, explore new areas for cooperation and coordinate bilateral activities. The New Zealand - Singapore relationship was further strengthened with the signing in 2008 of an Arrangement on Defence Cooperation. ${ }^{157}$

In summary, at its most basic level the purpose of training, personnel exchanges and exercises within the FPDA construct remains the preparation for the use of force in order to counterbalance and deter enemies. While the relationship has evolved over time, most recently being credited with enabling Singapore and Malaysia forces to deploy alongside New Zealand in Afghanistan, this development continued to reflect the original purpose of the Arrangements to build Singaporean and Malaysian defence capacity and enable the disparate forces to operate together.

The NZDF's objective of defence links with Asian FPDA partners was to build the capacity of their armed forces and maintain the ability to work with them on operations.

\footnotetext{
${ }^{156}$ Author's interview with senior MFAT official, 26 February 2013.

${ }^{157}$ New Zealand Defence Force, New Zealand Defence Force Annual Report 2009 (Wellington: New Zealand Government, 2009), 11.
} 
Having once opposed the relationship, or at least questioned its value in the 1980s, MFAT now recognises that the defence relationship serves wider foreign policy goals, reinforcing the political linkages between Malaysia and Singapore, and with and also between Australia, the UK and New Zealand. In recent times FPDA has been able to demonstrate New Zealand's usefulness to its other defence partners such as the United States and NATO by playing a large part in bringing Singapore and Malaysia into the international security efforts in Afghanistan.

\section{New Zealand's 'new' Defence Diplomacy}

The changed strategic environment in which the FPDA found itself in also accounts for the rise of 'new' defence diplomacy; the extension of New Zealand defence cooperation beyond that needed for preparing for and undertaking the use of force. Since the 1990s, the New Zealand military began to engage beyond traditional partners in Asia (like Singapore and Malaysia) and reach out to the armed forces of non-like-minded states.

But what explained New Zealand's broadened approach? Gerald Hensley, career diplomat and the Secretary of Defence between 1991 and 1999, described the change in the following way:

I think, in New Zealand, the concept of defence diplomacy is really security diplomacy. It well antedates the British or any other use of similar terms. It does so because I think that New Zealand's foreign policy has always oscillated between security and trade or economic security. Until Britain entered the common market [in 1973], our foreign policy was really focussed on security; the economics took care of themselves. We've now gone to the other pole, where in the midst of the long peace security has ceased to be a concern of our diplomacy and of course the trade and economic aspects have dominated. [...] South East Asia was becoming of economic interest to us rather than of security interest, and that was a very healthy change. ${ }^{158}$

In 1994, Don McKinnon the Minister of Foreign Affairs discussed the contribution of the NZDF to the development of trading relationships in Asia:

...when we come to trade with countries in the Asian region, we have to remember that they are not simply trading partners. They don't see themselves as just that and they don't regard us in that light either. We have to deal with

${ }^{158}$ Author's interview with Gerald Hensley, 22 March 2013. 
regional countries as a totality, including the security dimension. If we are to have influence in the region, if we are to have a rounded relationship with regional countries, we must be able to contribute - on the security side of the equation as well. ${ }^{159}$

Terence O'Brien, former New Zealand diplomat and senior fellow at the Victoria University of Wellington's Centre for Strategic Studies, explained the reason for the expansion of New Zealand's defence relationships beyond those countries we considered as allies.

New Zealand is actually moving into new territory. For most of the 20th century, our international security and our international prosperity interests were taken care of by our relationships and alliances with major western countries. What's happening now as we are moving into the 21 st century is that this marriage made in heaven between our economic interests and our security interests is actually being broken. Our economic interests now principally lie with countries that were not previously ones from whom we sought security. We have to, in my opinion, enlarge our security-type relationships, defence relationships with key nations in East Asia. ${ }^{160}$

The key fact underpinning New Zealand's 'new' defence diplomacy was the increased divergence of the country's security and defence interests on one hand, and its trade and economic interests on the other. As countries like China and others in Asia became increasingly significant trade partners for New Zealand, the significance of a wider range of relationships also grew. New Zealand's defence relations expanded to take account not only of New Zealand's traditional security arrangements, but also its economic and trade interests. The NZDF also recognised that changes in the regional security architecture provided New Zealand with a greater opportunity to interact with Asian countries on security and defence issues. ${ }^{161}$ Indeed, it is difficult to imagine defence relations thriving if it weren't for developments like the end of the Cold War, the establishment of the ASEAN Regional Forum as well as domestic political and social reforms.

It is important to remember it was not all about trade and economics. The conflict prevention role of New Zealand defence diplomacy has also been recognised. According

\footnotetext{
${ }^{159}$ Don McKinnon, "Building International Linkages: The Contribution of the Defence Force," Ministry of Foreign Affairs and Trade Record 2, no. 10 (April 1994): 14.

${ }^{160}$ Andrew Butcher and Terence O’Brien, Audio Interview by John Saunders, Audio, May 2012, http://www.asianz.org.nz/sites/asianz.org.nz/files/Asia\%20NZ\%20ASEAN\%20Small.mp3.

${ }_{161}$ International Defence Relations Branch, "New Zealand Defence Engagement with Southeast Asia" (Ministry of Defence, December 1, 2009), 1.
} 
to the New Zealand Ministry of Foreign Affairs, the NZDF built capacity for dialogue with defence counterparts in countries like China in order to deepen our defence and security understanding of the region and strengthen our engagement with individual countries. ${ }^{162}$ These activities were considered by MFAT to be a component of New Zealand's broader diplomacy and confidence-building efforts. Defence diplomacy assisted in conflict prevention by avoiding the security dilemma. This dilemma was described by Jim Rolfe as one "in which the military activities of one state are seen to be threatening to the security of another state. If the region's armed forces are well known to each other and familiar with each other's philosophies and procedures, the reasoning goes, they are more likely to talk about security issues than react defensively to them."163

Looking at the management of defence diplomacy for a moment, the importance of defence relations for the New Zealand defence establishment was reflected in the fact that the International Defence Relations (IDR) Branch was a jointly-funded strategic level capability shared by the Ministry of Defence and the NZDF. ${ }^{164}$

The role of IDR was to contribute policy advice integral to the 'NZ Inc' network. 'NZ Inc' was a set of strategies designed to deliver improved strategic planning, coordination and efficiency among New Zealand government agencies. IDR assisted by providing policy advice to the Chief of Defence Force and the Secretary of Defence on deployments, defence relations with overseas partners and participation in multilateral security forums.

IDR was established in 2000 in order to rectify a policy gap between NZDF and MoD. ${ }^{165}$ Some friction continues within IDR between NZDF, which focuses on current and near term operational matters, and the MoD, which looks more toward longer-term capability, other government agencies and foreign policy. According to the NZDF, this friction created gaps in understanding, priorities, resourcing and the rate of effort between the two

\footnotetext{
${ }^{162}$ New Zealand Ministry of Foreign Affairs and Trade, Our Future with Asia, 23.

${ }^{163}$ Jim Rolfe, “Jousting with Jakarta," New Zealand Defence Quarterly (Autumn 1995): 11.

${ }^{164}$ New Zealand Defence Force, Annual Plan 2011/2012 (Wellington: New Zealand Government, 2011), 83.

${ }^{165}$ Author's interview with Paul Sinclair, 28 November 2012.
} 
organisations. ${ }^{166}$ The Ministry however, supplied the bulk of the staff ${ }^{167}$ and, at the time of writing, there were no NZDF staff remaining in the Branch. ${ }^{168}$

Within the NZDF and following criticism that the informal and ad hoc advice hitherto provided was of limited use, a Defence International Engagement Framework was instituted to provide policy and guidance to decide the focus and amount of effort expended and in which countries. ${ }^{169}$ The Framework set annual priorities for NZ's security partnerships with other nations and, according to the NZDF, was aligned with New Zealand's foreign policy objectives. ${ }^{170}$

\section{Multilateral cooperation}

One interesting corollary of 'new' defence diplomacy was the rise of multilateral defence diplomacy. The growing range of regional multilateral forums became one of the significant ways in which New Zealand engaged with non-like-minded partners. The proliferation of multilateral defence dialogues in the region, such as the ASEAN Defence Ministers Meeting Plus Eight (ADMM+), the ASEAN Defence Senior Officials Meeting Plus Eight $(\mathrm{ADSOM}+)$, the Shangri-La Dialogue, the Jakarta International Defence Dialogue, and most recently, the Seoul Defence Dialogue, was ascribed to the need for collective capabilities and multinational efforts to deal with diverse and rapidly changing security threats. ${ }^{171}$

Multilateral defence diplomacy offered an acceptable alternative to more traditional alliance arrangements as they appealed to the reluctance of Asian nations to become involved in formal security relationships. Viet Nam for example, explicitly refused to

\footnotetext{
166 New Zealand Defence Force, Annual Plan 2011/2012, 84.

167 Ibid.

168 Author's interview with Paul Sinclair, 28 November 2012.

${ }^{169}$ New Zealand Ministry of Defence, Management of the NZDF's Programme of International Commitments (Wellington, N.Z.: New Zealand Government, 2011), 5,

http://www.defence.govt.nz/pdfs/reports-publications/evaluation-report-7-2011-management-of-the-nzdfsprogramme-of-internationasl-commitments.pdf.

${ }^{170}$ New Zealand Army, "International Engagements," What We Do, April 3, 2013, http://www.army.mil.nz/about-us/what-we-do/international-engagements/default.htm.

${ }^{171}$ Jung Sung-Ki, "Seoul Launches New Forum for Asia Pacific Security Talks," Defense News Website (November 9, 2012), http://www.defensenews.com/artcile/20121109/DEFREG03/311090007/SeoulLaunches-New-Forum-Asia-Pacific-Security-Talks.
} 
enter into any alliance, but that did not prevent it from undertaking defence diplomacy. ${ }^{172}$ Likewise, Indonesia has been traditionally reluctant to enter into alliance arrangements and sensitivities about Indonesian domestic opinion on the issue was a frequent factor that limited aspects of New Zealand's defence relations with Indonesia, such as visits and exercises. ${ }^{173}$ China has a long-standing policy of non-alignment as part of its independent and self-reliant foreign policy of peace, ${ }^{174}$ yet has pursued an active military diplomacy programme since the $1990 \mathrm{~s}$.

Asian nations also tended to favour bilateral relationships. Even within multilateral settings, government officials from Asian nations undertook many short bilateral meetings, several in order to conclude formal agreements, ${ }^{175}$ while wider multilateral discourse resulted in non-legally binding declarations and statements. ${ }^{176}$ Laksmana insisted that multilateral defence diplomacy in South East Asia had to be viewed together with bilateral defence relations. He viewed them as two sides of the same coin; with bilateral relationships being primarily concerned with specific state defence issues, while multilateral relationships were aimed more at balancing the influence of the major powers. He further differentiated them by arguing that bilateral links were regarded as better suited to the discussion of 'hard' defence issues, while multilateralism tended to be the venue for discussion of 'less-significant' non-traditional security issues. ${ }^{177}$ Despite the rise of multilateral forums, bilateral relationships with South East Asian states remained a crucial part of the regional security architecture. For example, while ADMM is intended to strengthen defence and security cooperation by providing a platform for open and constructive dialogue and to promote practical cooperation among the armed forces of ASEAN members, participants cannot discuss strategic-level issues at the highest level, because these are beyond the ministerial prerogative of defence ministers. ${ }^{178}$

\footnotetext{
${ }^{172}$ Malcolm Moore and Praveen Swami, "Viet Nam Offers Cam Ranh Bay Navy Base to Foil China," The Telegraph, November 8, 2010, http://www.telegraph.co.uk/news/worldnews/asia/Viet Nam/8116192/Viet Nam-offers-navy-base-to-foil-China.html.

${ }^{173}$ New Zealand Defence Attaché, Defence Cooperation with Indonesia, June 1, 1974, Jakarta File 30/4/1.

${ }^{174}$ Feng Zhang, “China's New Thinking on Alliances,” Survival 54, no. 5 (November 2012): 129-148.

${ }^{175}$ Capie and Taylor, "The Shangri-La Dialogue and the Institutionalization of Defence Diplomacy in Asia," 12.

${ }^{176}$ Evan A. Laksmana, "Defence Diplomacy in South East Asia : Trends, Prospects and Challenges," in From "Boots" to "Brogues": The Rise of Defence Diplomacy in Southeast Asia, RSIS Monograph 21

(Singapore: S. Rajaratnam School of International Studies, 2011), 88.

177 Ibid., 87.

${ }^{178}$ Joann Saw, ed., "Defence Diplomacy in South East Asia: Conference Report" (Singapore: S. Rajaratnam School of International Studies, 2010), 7.
} 
The network of bilateral defence relationships in South East Asia is extensive. As early as 1989, Indonesian General Try Sutrisno characterised the number of bilateral defence linkages between ASEAN states as "like a spider web". ${ }^{179}$ Bilateral activities, which often entail military exercises, tend to be more expensive and some nations are reluctant to conduct bilateral defence cooperation for this reason. New Zealand officials have found multilateral activities, on the other hand, more accessible as they were likely to only require the dispatch of a small delegation of officials or a single military platform for a limited time. New Zealand does not have a preference either way, but multilateral activities have a number of advantages for small militaries. Dr Wayne Mapp, former Defence Minister observed that "the great advantage was that they brought everyone together so you could get round everyone fairly quickly, so that's pretty important. It made you think of the issues that affected the region as a whole." ${ }^{180}$ Former Secretary of Defence John McKinnon commented that "if you had to choose between participating in a multilateral exercise and a bilateral one, you might opt for the multilateral [exercise] because you literally get a bigger bang for your buck."181 However, he also noted "if you are doing a multilateral thing in the region, what you try to do is clip on bilateral activities. [...] The multilateral activity might give you more reach but it may be less useful militarily than a bilateral activity. It might have more of a diplomatic point than a military point." ${ }^{\prime 12}$ New Zealand recognises the different roles each of these multilateral institution plays in the regional security architecture. As a senior MFAT official explained when talking about ADMM+:

It filled a gap in some of the other regional organisations that focus on those sorts of issues. You had the likes of the Shangri La Dialogue, which is a policy dialogue; the ASEAN Regional Forum which is quite limited by some of the dynamics. It was meant to be the mechanism for preventative diplomacy and it's never really fulfilled that potential because there's too many brakes placed on it by various players. So to have something like the ADMM+, which has policy dialogue but also engages the military around practical themes is an extremely useful piece of confidence-building. It is quite solutions-focused too. ${ }^{183}$

\footnotetext{
${ }^{179}$ Amitav Acharya, "A Survey of Military Cooperation Among the ASEAN States: Bilateralism or Alliance? Occasional Paper No. 14" (Centre for International and Strategic Studies, May 1990), 2.

${ }^{180}$ Author's interview with Dr Wayne Mapp, 14 March 2013.

181 Author's interview with John McKinnon, 7 March 2013.

182 Ibid.

${ }^{183}$ Author's interview with senior MFAT official, 15 February 2013.
} 


\section{Issues and Dilemmas of New Zealand's Defence Diplomacy.}

From this chapter and the one preceding it, it is apparent that the conduct of defence diplomacy created issues and posed a number of dilemmas. Issues often encountered in the conduct of defence diplomacy included the amount of reciprocal activity and openness that needs to be provided or should be expected from such new defence partners, and how competing interests between support for democracy and the development of good civil-military relations are balanced. Conducting defence diplomacy also requires the armed forces themselves to reconcile what was hitherto considered their core role in preparing for conflict with how far they should engage potential adversaries and its possibility of compromising the former. Partners in defence diplomacy often have different motivations and purposes in mind, and differences in these perspectives also had the ability to create tensions within relationships. There is also the recent burgeoning in multilateral engagement between defence establishments, and what this means for bilateral engagement, to consider. This section seeks to explore some of these issues from New Zealand's perspective.

\section{Balancing cooperation between 'old' and 'new'}

Cottey and Forster recognised that 'new' defence diplomacy existed alongside 'old', and there are tensions between them. Efforts to strengthen the military capabilities of allies created problems in strategic engagement with former foes, while strategic engagement with these former foes potentially risked undermining the ability to defend allies against these states. ${ }^{184}$ Perhaps the very first of these dilemmas is the question of whether it is right or prudent to engage a former or potential enemy, particularly in the military arena where engagement requires transparency and openness. Such questions are not new. ${ }^{185}$ For example, during a visit to the United States by Chinese Chief of Staff General Chen Bingde, United States lawmakers objected to their Chinese guests being able to view advanced military technology. ${ }^{186}$ These objections arose from a perspective that defence diplomacy activities provide a means of improving the military capabilities of states. Indeed, the Chinese (and many others) describe one of the purposes of their defence relations as improving their military capabilities. But perspectives that non-like-minded

\footnotetext{
${ }^{184}$ Cottey and Forster, Reshaping Defence Diplomacy, 12.

${ }^{185}$ Geoffrey R Berridge, Talking to the Enemy: How States Without "Diplomatic Relations" Communicate (Houndmills: Macmillan, 1994), xiii.

${ }^{186}$ Bill Gertz, "Chinese to View Sensitive U.S. Sites: Lawmaker Sees Violation," The Washington Times, May 18, 2011.
} 
countries like China are "...not allied or even friendly..." $" 187$ will continue to vex the conduct of defence diplomacy.

Another objection to defence diplomacy is that it might distract the armed forces from their core business of preparing to fight wars. From informal conversations with NZDF personnel and reading New Zealand military doctrine, defence engagement with a range of other countries, including non-like-minded states is a key role of the Defence Force and is pursued as a conflict prevention objective. On this subject, former Secretary Defence John McKinnon explains:

Defence diplomacy is an outflow of defence core business. [...] Establishing and maintaining channels of communication with other militaries understanding what other militaries are about - is a very important part of figuring out what you as a military yourself are doing. It's not a distraction; it's an input into that core business. ${ }^{188}$

This is not the only way in which tensions arose between 'old' and 'new' defence diplomacy. New relationships with former and potential adversaries have to be carefully managed to make sure they do not interfere with or complicate traditional relationships between allies, about what information, training and capabilities were being shared for example. Two key examples are the FPDA and its impact on defence diplomacy with Indonesia, or defence links with China and their impact on traditional links with Australia and the United States. Paul Sinclair noted that New Zealand is "very careful to manage the newer relationships in a way that does not impinge or limit our ability to conduct our relationships with long-standing partners, be they five-eyes partners or Five Power Defence Arrangements partners." 189 John McKinnon added that "...it is inherent in the nature of this business that you are managing relationships with a variety of partners. The skill is to do this in a way which allows you maximum ability to do so."190

\section{Bureaucratic rivalry and primacy}

Institutional primacy relates to the question of whether it should it be the diplomats or the military who decide the focus of defence diplomatic efforts. Furthermore, there may be

\footnotetext{
187 Ibid.

188 Author's interview with John McKinnon, 7 March 2013.

${ }^{189}$ Author's interview with Paul Sinclair, 28 November 2012.

${ }^{190}$ Author's interview with John McKinnon, 7 March 2013.
} 
rivalry between the defence establishment and the foreign service, about who sets the policy direction of cooperative activities carried out by the armed forces, such as where and how much defence cooperation with certain states is appropriate. This was more significant in cases where the nation being engaged was a military regime or where the foreign ministry's diplomatic corps either lacked access or had been downsized. Such matters also give rise to questions over civilian oversight of the military's activities. Conversely, as defence becomes conflated within "all of government" (commonly known in New Zealand as "NZ Inc") approaches to other countries, there is also the danger of institutional convergence particularly where there was a large security and defence element in the relationship.

In New Zealand's case, this does not seem to be a significant issue. There is broad acceptance within Defence of the notion that defence is a sub-set of foreign policy, while the small size of New Zealand's bureaucratic system meant that issues tended to be coordinated between a variety of agencies anyway. As former Ambassador Tony Browne pointed out; "this is not an issue in New Zealand. Defence would never claim primacy in determining the nature of a political relationship. There are times where [...] the extent to which there is defence input into key decision-making goes up and down..."191 Defence and foreign affairs officials agreed that defence would coordinate the 'nuts and bolts' or day-to-day aspects of relationships, while high level direction and policy would be decided at the interagency level, likely involving not only defence and foreign affairs, but also other interested agencies such as the Department of the Prime Minister and Cabinet. There were no reservations from foreign affairs officials about the role the defence force was building with these new partners. For example, on the Chinese defence relationship Tony Browne commented, "we too see the relationship with China as something that benefits from having a broad base, not a narrow base."192 Primacy concerns not only who provides the policy direction, but also raises another issue of the militarisation of foreign policy. This was a particular concern where the military was being used as the de facto diplomatic representation. Again, foreign affairs officials welcomed the addition of defence ties into the range of diplomatic relations, one official admitting "I think defence establishments moving into this soft diplomacy space is a good move, I don't think

\footnotetext{
191 Author's interview with Tony Browne, 11 March 2013.

192 Ibid.
} 
[primacy] is a problem for New Zealand defence but in defence establishments like Viet Nam it is easy to see a military solution to everything." 193

\section{Conditionality}

The imposition of conditions on defence relations can have a significant impact on their conduct. For example, the military relationship between the United States and China has not evolved past the discussion of broad strategic issues despite military cooperation dating back to the 1980 s, due to conditions being applied by both sides, which has resulted in impediments to and, in some cases, suspension of military engagement. ${ }^{194}$ New Zealand does not apply conditions to its broader diplomatic relationships. Speaking about relations with one party states, a senior foreign affairs official explained:

...in my opinion, within the New Zealand political system there was much more of a sense that you deal with people across the board and you don't have to wait until countries become democratic. ${ }^{195}$

In New Zealand's case, defence relations with Indonesia provide the best example of conditionality, but other recent examples include Thailand and Fiji which have had defence cooperation cut due to New Zealand's concerns over their armed forces' role in domestic politics. Another aspect of conditionality is the dilemma posed by cooperating with authoritarian regimes. Visits and exchanges between defence forces are often credited with assisting in the development of norms of behaviour, like good civil-military relations for example, in those forces being engaged. A dilemma is posed by the choice between cooperating with an authoritarian regime to promote democracy, civil-military relations and respect for human rights and face criticism that the engagement is not working (that is, not improving democracy, civil-military relations or the human rights situation), or alternatively, cut defence cooperation and lose what little influence there might have been over the regime. This dilemma is particularly acute when the regime in question is a military dictatorship or where the military has a particularly close relationship to the ruling party in political power. In New Zealand's case, the defence

\footnotetext{
193 Author's interview with senior MFAT official, 15 February 2013.

194 "US Seeks Greater Military Ties with China," Agence France-Presse, January 27, 2012, http://www.google.com/hostednews/afp/article/ALeqM5iGmrtFboRvHxJCrS6PHE1Qa538A?docId=CNG.871f4204301feda9723a1cb343f5afe3.241.

${ }^{195}$ Author's interview with senior MFAT official, 15 February 2013.
} 
relationship with Indonesia from 1974 onwards is the prime demonstration of how this dilemma plays out.

\section{Reciprocity}

Cottey and Forster identified reciprocity as another dilemma that often emerged in the conduct of defence diplomacy; the question of whether defence diplomacy should be mutual. Where it is not, problems occur when one state is perceived to concede more than others, as is the case between the United States and China, ${ }^{196}$ or where transparency may be vulnerable to abuse, as regular allegations of spying attest. ${ }^{197}$ In order for defence diplomacy to work, a balance must be found between reassurance and transparency on one hand, and developing reciprocity on the other. China used military diplomacy to reassure selected countries; enhance China's image as a responsible member of the international community; gain access to foreign military technology and expertise; and deter threats to stability by demonstrating the PLA's improving capabilities. ${ }^{198}$ The inclusion of the last one is of significance to the issue of reciprocity; because this was an accusation often levelled at United States military diplomacy efforts by China, and was used as a reason for China not reciprocating in military exchanges. ${ }^{199}$

One means of getting around this issue has been to focus defence diplomacy activities on less contentious areas such as peacekeeping, search and rescue, and humanitarian assistance and disaster relief; all areas where the need to access and share hightechnology military capabilities are minimal. Many defence diplomacy activities around the world have been initiated in such areas where both parties are comfortable to operate. Dr Wayne Mapp, the New Zealand Defence Minister, provided another reason for regional militaries to cooperate in disaster relief in a speech to the 2010 Shangri-La Dialogue.

International assistance does involve questions of sovereignty and international jurisdiction. We must, therefore, ensure that all parties are comfortable with the means for delivery. [...] One of the key challenges for defence forces used to

\footnotetext{
${ }^{196}$ Gertz, "Chinese to View Sensitive U.S. Sites: Lawmaker Sees Violation,” 1.

${ }^{197}$ Ibid.

198 Army War College (U.S.). and Roy Kamphausen, The PLA at Home and Abroad Assessing the Operational Capabilities of China's Military (Carlisle, PA :: Strategic Studies Institute, U.S. Army War College,, 2010), 430.

${ }^{199}$ Kenneth Allen and Eric A. McVadon, China's Foreign Military Relations (Washington D.C.: Henry L. Stimson Center, 1999), 44.
} 
training for combat is building a better understanding of relief operations. This means giving confidence to recipient countries that the defence presence from other countries does not infringe the sovereignty of states. ${ }^{200}$

The NZDF has held search and rescue exercises with the People's Liberation Army (Navy) which took place within a New Zealand and Australian combined maritime war fighting exercise. ${ }^{201}$

In a twist on defence diplomacy, the concept of disaster diplomacy was coined to describe the potential for the use of military assets for humanitarian objectives to institutionalise a framework for military to military engagement between enemies or where there is little tradition of multilateral security cooperation. ${ }^{202}$ Others have suggested environmental cooperation, in areas such as energy use, responses to climate change and disaster relief for example, as an appropriate and a productive avenue for military cooperation. ${ }^{203}$

Another way to get around reciprocity is to engage other defence forces in multilateral defence diplomacy. In a multilateral forum, all parties can expect to receive roughly the same amount of benefit in aggregate over a period of time, and specific reciprocity becomes less of an issue. ${ }^{204}$

\section{Clash of purposes}

Problems have arisen when countries view the defence diplomacy activities of others with suspicion. China and the United States for example readily acknowledged that each country had a "difference in philosophy" on what military-to-military relations entailed and that there were problems with trust. ${ }^{205}$ Because China viewed their foreign military relations as a means to develop friendly relations with other nations and modernise their

\footnotetext{
${ }^{200}$ International Institute for Strategic Studies, "Fourth Plenary Session Humanitarian and Disaster Relief in the Asia-Pacific," Shangri-La Dialogue 2010, June 5, 2010, www.iiss.org/conferences/the-shangri-ladialogue/shangri-la-dialogue-2010/plenary-session-speeches/fourth-plenary-session/wayne-mapp. ${ }^{201}$ Gill Bates, Rising Star: China's New Security Diplomacy (Washington, D.C.: Brookings Institution Press, 2007), 67.

${ }^{202}$ Ilan Kelman, "Disaster Diplomacy: Can Tragedy Help Build Bridges Among Countries?," UCAR Quarterly (Fall 2007): 6.

${ }^{203}$ Kent Hughes Butts and Geoffrey D. Dabelko, "One Way to Boost US-China Military Cooperation," Christian Science Monitor, accessed March 3, 2012, http://www.csmonitor.com/Commentary/Opinion/2009/0421/p09s01-coop.html/(page)/2.

${ }^{204}$ Capie and Taylor, "The Shangri-La Dialogue and the Institutionalization of Defence Diplomacy in Asia," 12.

205 "US Seeks Greater Military Ties with China."
} 
military, some countries (particularly the United States and certain elements within it) saw this as a means for China to acquire military hardware and technology, to expand their military presence, and to intimidate its neighbours.

For New Zealand, issues about access and release of information prejudicial to security seem to have been less of a consideration. The NZDF operates technology, such as tactical radios and thermal sights supplied primarily by the United States as a result of an extensive and ongoing programme of reshaping and rebuilding military capabilities over the last decade. In addition the NZDF utilises doctrine and tactics that are not intended to be disclosed beyond its traditional defence partners. Such equipment and procedures were supplied on the proviso they are kept safe from third parties. This was straightforward for the NZDF to achieve as such defence articles were few and far between and easily contained in secure areas. The NZDF Command and Staff College, who taught a number of students from countries including Viet Nam and China, ${ }^{206}$ did close sessions to these students, but actively sought to limit the need to do so. ${ }^{207}$

\section{Conclusion}

The FPDA provides an example of New Zealand's traditional defence relationships or 'old' defence diplomacy. It is characterised as such by its links with key allies for the purpose of enhancing military capability towards building interoperability between the partner forces.

However, noting the way in which New Zealand's FPDA partners have developed over the last forty years and in light of comments from MFAT officials, it is readily apparent that what was once an 'old' defence relationship with the FPDA countries has morphed into a form of 'new' defence diplomacy, in that it is conducted for both broader political and economic purposes and for military purposes. As a result, despite its initial rationale having faded over time, the FPDA continues to exist as a strongly supported and active set of relationships. It has evolved over time to overlap and complement with, rather than compete with or replace traditional bilateral alliances or ASEAN multilateralism.

\footnotetext{
${ }^{206}$ New Zealand Defence Force, "Defence Diplomacy," Command and Staff College, March 16, 2011, http://www.nzdf.mil.nz/corporate/command-and-staff-college/defence-diplomacy/default.htm.

${ }^{207}$ Author's interview with Cdr Shaun Fogarty, 12 December 2012.
} 
Having reviewed New Zealand's 'old' defence diplomacy and the range of new relationships, it is appropriate to look more intently at New Zealand's defence cooperation with some of these key new partners. The NZDF's newer relationships, with countries like China, Viet Nam and the renewed relationship with Indonesia, provide examples to explore the way in which defence ties evolve, and serve to illustrate how the key issues raised by Cottey and Forster and other commentators on the concept play out in New Zealand's experience. 


\section{Chapter Four New Zealand's defence relations with the People's Republic of China}

\section{Introduction}

One of the most extraordinary events in international relations of the last two decades has been the economic rise of China and it's far reaching effects. Some readers may ask why, in this day and age, China is discussed in this paper as a former or potential enemy. Indeed, there is a great deal of sensitivity about discussing China from a security perspective in New Zealand. New Zealand and China fought as belligerents in the Korean War, in which New Zealand artillery provided support to the British Commonwealth Brigades during the battles of Maryang San, Kapyong and the Samichon River against the Chinese People's Volunteer Army. After the Korean War, when New Zealand entered into the South East Asian Treaty Organisation (SEATO) alliance in 1954, it was in response to the threat posed by China. ${ }^{208}$ SEATO lasted until 1972, following US-Chinese rapprochement and the year in which New Zealand first recognised the People's Republic as the legitimate government of China. ${ }^{209}$

Despite the granting of diplomatic recognition, New Zealand opinions of China continued to be considerably influenced by the perception of friendly South East Asian governments, which felt themselves under the continued threat from Chinese Communist subversion. ${ }^{210}$ These included our closest allies Singapore and Malaysia, and also Indonesia. As military historian Peter Cooke argues, "as a communist country and a country that provided military support to North Vietnam [...] China was seen, in a Cold War context, as being a potential enemy." 211 Further development of New Zealand's relationship was able to take place as reforms initiated within China under the rule of Deng Xiaoping led China to develop a market economy and a less ideological and more pragmatic political approach, which opened China up to the world. Relations developed

\footnotetext{
${ }^{208}$ Rolfe, New Zealand's Security, 7.

${ }^{209}$ James Kember, Paul Clark, and New Zealand Asia Institute (University of Auckland), China and New Zealand: a Thriving Relationship Thirty Years On (Auckland, N.Z.: New Zealand Asia Institute, University of Auckland, 2003), 99.

${ }^{210}$ Ibid., 28.

${ }^{211}$ Peter Cooke, Report on Medallic Recognition of New Zealand Military Service in South-East Asia 19501975 (Wellington, N.Z.: New Zealand Defence Force, 2011), 57, http://medals.nzdf.mil.nz/seasia/documents/jul2011-seasiafullreport1950-1975.pdf.
} 
slowly, but accelerated over time and the relationship with China is one of New Zealand's most important bilateral partnerships. ${ }^{212}$ Foreign policy talks, together with economic and trade talks, are held regularly. More members of the Communist Party central committee visited New Zealand in the past decade than almost any other country. ${ }^{213} \mathrm{New}$ Zealand and China signed a free trade agreement in April 2008. There is regular contact on a wide range of issues including law and governance, human rights, international fisheries management, agriculture, dairy, forestry and developmental assistance as well as regional security and defence. Helen Clark, the New Zealand Prime Minister between 1999 and 2008, herself stated "it can be deduced from this interaction and dialogue that our Government does not see China as a threat." ${ }^{214}$

Nevertheless, despite espousing an "independent foreign policy of peace"215 and the Five Principles of Peaceful Coexistence for over two decades, the occasionally heated rhetoric and actions of the Chinese government coupled with its lack of transparency continues to complicate attempts to understand China's approach to international relations.

China's seeming willingness to use force in territorial disputes with its neighbours and the development of Chinese advanced military capabilities have added to this uncertainty. As a result, the China threat debate continues to dominate much of Western strategic thought. There have been questions raised in New Zealand over China's behaviour; for instance, despite Helen Clarke's assertion, China has been behind cyber attacks on New Zealand government agencies. ${ }^{216}$

There is not a great deal of official comment about the New Zealand-China defence relationship. Ayson pointed out that New Zealand's defence policy is reluctant to go into much detail at all about China. ${ }^{217}$ China was briefly described as one of the "pivotal"

\footnotetext{
${ }^{212}$ Statistics New Zealand, "New Zealand in Profile: 2012 - Statistics New Zealand," Main Trading Partners, 2011 (NZ\$ Million), accessed April 22, 2012, http://www.stats.govt.nz/browse_for_stats/snapshots-of-nz/nz-in-profile-2012/imports.aspx. ${ }^{213}$ Audrey Young, "US Keen on NZ-China Link," New Zealand Herald, December 17, 2012, http://www.nzherald.co.nz/nz/news/article.cfm?c_id=1\&objectid=10854525.

${ }^{214}$ Kember, Clark, and New Zealand Asia Institute (University of Auckland), China and New Zealand, 103.

215 Ma Zhengang, “China's Independent Foreign Policy of Peace," The RUSI Journal 143, no. 1 (1998): 14, doi:10.1080/03071849808446220.

${ }^{216}$ New Zealand Ministry of Foreign Affairs and Trade, "Republic of Singapore."

217 Ayson, "Force and Statecraft: Strategic Objectives and Relationships in New Zealand's 2010 Defence White Paper," 25.
} 
major powers in East Asia on whose actions rest regional peace and security. ${ }^{218}$ However, our closest security partners were not as reticent, with Australia acknowledging the potential for the pace, structure and scope of China's military modernisation to give its neighbours cause for concern and create questions over its long-term strategic purpose. $^{219}$ As former Secretary of Defence John McKinnon observed "China is a major power in the region. It has significant military assets. It has a variety of national objectives. Some of these obviously impinge on us, either regionally or more broadly. Therefore, from our point of view, understanding what is motivating or driving the Chinese is important. ${ }^{220}$ One means to gain that understanding has been a formal defence relationship with the People's Republic of China since 1998.

\section{The development of Sino - New Zealand Defence Diplomacy}

It was not until 1979, when China introduced its policy of opening up to the outside world, that military exchanges with other countries grew substantially. ${ }^{221}$ The increasing frequency and sophistication of China's defence diplomacy mirrored China's wider engagement in the international community. ${ }^{222}$ Between 1987 and 1999, the number of Chinese defence attaché offices abroad had increased from 60 to 99, while the number of foreign missions in China increased from 40 to $65 .^{223}$ The PLA was considered as an important 'new' actor in Chinese foreign policy due to its continued professionalisation and its increasing contacts and cooperation with the outside world. ${ }^{224}$ Most significant was the recognition that the PLA's mind-set appeared to be developing along a dual-track trajectory: one track that was more nationalistic and another that was more willing to engage in international cooperation and dialogue. ${ }^{225}$

The first peacetime military contact between China and New Zealand took the form of a goodwill visit by two Royal New Zealand Navy frigates, HMNZS Canterbury and Southland, to Shanghai during a regional deployment in 1987. At the time New Zealand

\footnotetext{
${ }^{218}$ New Zealand Ministry of Defence, Defence White Paper 2010, 19.

${ }^{219}$ Australia. Dept. of Defence., Defending Australia in the Asia Pacific Century : Force 2030 : Defence White Paper 2009 ([Canberra]: Dept. of Defence, 2009), 34.

${ }^{220}$ Author's interview with John McKinnon, 7 March 2013.

${ }^{221}$ Allen et al., China's Foreign Military Relations, 5.

${ }^{222}$ Army War College (U.S.). and Kamphausen, The PLA at Home and Abroad Assessing the Operational Capabilities of China's Military, 429.

${ }^{223}$ Allen et al., China's Foreign Military Relations, 5.

${ }^{224}$ Linda Jakobson and Dean Knox, New Foreign Policy Actors in China (Stockholm: Stockholm International Peace Research Institute (SIPRI), 2010), 15.

${ }^{225}$ Ibid.
} 
Prime Minister David Lange described the visit as adding another strand to the relationship between the two countries, and noted that it reflected "the importance which we attach to building on the base of familiarity and goodwill that has grown up between New Zealand and China, a country of very great political and economic weight in our region." 226 This sentiment became a familiar theme.

New Zealand's formal military relationship with the People's Republic of China dates back to 1998, when New Zealand and China each established resident defence attachés in Beijing and Wellington respectively. But it was two successive high-level exchanges that paved the way toward this watershed in the relationship. The first, in May 1996, saw PLA Deputy Chief of General Staff, Lieutenant General Xiong Guangkai visit New Zealand. He met with senior Cabinet Ministers and held talks with Gerald Hensley, Secretary of Defence and Lieutenant General Anthony Birks, Chief of Defence Force. Xiong usually made brief visits of one or two days duration, met only with senior military leaders and only on rare occasions gave speeches at defence universities. ${ }^{227}$ On this occasion General Xiong delivered a presentation at Victoria University, in which he espoused China's defence policy, ${ }^{228}$ a similar theme to his meeting with senior defence officials. ${ }^{229}$ General Xiong was the driving force behind the expansion of the PLA's defence diplomacy efforts over the course of the 1990s and was the next most important person in the PLA's foreign relations programme beside the Defence Minister. ${ }^{230}$ He was responsible for initial approval of the PLA's foreign relations programme and could sign off on functional-level exchanges with other countries. ${ }^{231}$ At the time New Zealand defence relations were established, Xiong was new into his post.

The second exchange saw the New Zealand Secretary for Defence, Gerald Hensley, visit China, where the two sides agreed to further strengthen the high-level strategic dialogue and exchange resident Defence Attachés.

\footnotetext{
${ }^{226}$ New Zealand Ministry of Foreign Affairs and Trade, "Links with Other Countries," New Zealand Foreign Affairs Review 37, no. 4 (1987): 29.

${ }^{227}$ Allen and McVadon, China's Foreign Military Relations, 5.

${ }^{228}$ Dickens, Lessening the Desire for War: The ASEAN Regional Forum and Making of Asia Pacific Security, 13.

${ }_{229}^{229}$ Author's interview with Gerald Hensley, 22 March 2013.

${ }^{230}$ Allen and McVadon, China's Foreign Military Relations, 5.

${ }^{231}$ Ibid.
} 
These early exchanges likely came about after mutual military contacts on the fringes of the ASEAN Regional Forum meetings, first held in 1994. ${ }^{232}$ At the time, New Zealand was an ASEAN Dialogue Partner, while China was a Consultative Partner. Chris Elder, the New Zealand Ambassador to China at the time, confided that a Chinese delegate once told him "the greatest dividend of the ASEAN Regional Forum was getting the PLA out of China to see the real world."233

Opportunity knocked when a senior Chinese General transited through New Zealand in May 1995. Gerald Hensley, the Secretary of Defence at the time, explained that:

It was the first high-level passage through New Zealand. [...] I thought this was an opportunity we mustn't miss. So I went up to Auckland [...] and essentially made clear to him that we were interested in increasing our defence relationship in modest useful ways. This fell on fruitful ears and was followedup by General Xiong's visit a year or two later. ${ }^{234}$

The Chinese General on his way through Auckland to South America was Xu Huizi, Deputy Chief of General Staff. ${ }^{235} \mathrm{Xu}$ was heavily involved in defence diplomacy activities $^{236}$ and, notably, was a Korean War veteran. ${ }^{237}$ Thus it was in this manner that New Zealand initiated the Sino-New Zealand defence relationship.

\section{The purpose of Sino - New Zealand Defence Diplomacy}

Defence and foreign affairs officials in New Zealand both agreed that the Chinese (as well as many other Asian countries) simply regard a defence and security relationship as a component of a well-rounded wider relationship. ${ }^{238}$ Former Ambassador to China and Secretary of Defence John McKinnon observed:

\footnotetext{
${ }^{232}$ Author's interview with Chris Elder, 27 March 2013.

${ }^{233}$ Ibid.

${ }^{234}$ Author's interview with Gerald Hensley, 22 March 2013.

${ }^{235}$ Huang Guifang, "Promoting China-New Zealand Relations Towards the 21st Century," in New Zealand and China Present and Future, ed. Tim Beal and Yongin Zhang (Wellington, N.Z.: Victoria University Press, 1996), 204.

${ }^{236}$ Shirley A. Khan, U.S. - China Military Contacts: Issues for Congress, RL32496 (Congressional Research Service, 2010), 49-51.

237 "Xu Huizi," China Vitae, accessed March 26, 2013, http://www.chinavitae.com/biography/Xu_Huizi/full.

${ }_{238}$ Author's interview with Paul Sinclair, 28 November 2012; Author's interview with Tony Browne, 11 March 2013; Author's interview with John McKinnon, 7 March 2013.
} 
The military are an important part of China. Therefore from New Zealand's broader political and strategic objectives, understanding the Chinese military is important and defence links are the way you do that. By connecting with them directly you have to do that through defence channels. It is a component of that broader relationship; it's not by any means the most important part of it but it's one that we've wanted to nurture. ${ }^{239}$

Regarding New Zealand's gains however, it was easy to overemphasise the value of the defence engagement in terms of the benefits to the wider relationship. While the Defence IDR Branch argued that our defence links gave us access to the higher echelons of the Chinese Politburo during free trade negotiations, ${ }^{240}$ the Ambassador to China at the time saw the defence relationship as more of a "tick in the box" and it was a stretch to think the defence relationship contributed materially to the free trade agreement. As he explained:

China's decision to engage in a free trade agreement is a highly political decision; it wasn't one that was driven by economic calculations. ...in making that decision to get into that negotiation China was making a statement about how it viewed the broader relationship with New Zealand. ${ }^{241}$

From China's perspective, in the beginning, as Gerald Hensley explained:

[China] wanted to show it was not a threat, it did not intend to be an aggressive power, that everyone who was a bit nervous about the rapidity of their rise could relax. They chose New Zealand because we're so small that it didn't raise any awkward questions. As with the free trade agreement, if they could demonstrate the ability to comfortably manage a relationship with a small country like New Zealand, then other countries would think "they can manage us. $" 242$

The Australian Department of Defence Secretary was invited to China soon after Gerald Hensley visited in 1997. It was surmised that the Chinese thought it was best to start with New Zealand which "carried less alliance and other baggage." 243 New Zealand was attractive to the Chinese as a diplomatic misstep would have few consequences, as opposed to one with the United States for example. It was also likely to be in New Zealand's wider trade interests to overlook such missteps if they were ever to occur.

\footnotetext{
${ }^{239}$ Author's interview with John McKinnon, 7 March 2013

${ }^{240}$ Author's interview with Paul Sinclair, 28 November 2012.

241 Author's interview with Tony Browne, 11 March 2013.

242 Author's interview with Gerald Hensley, 22 March 2013.

243 Ibid.
} 
When pressed for specific benefits that China achieves from a defence relationship with New Zealand, defence officials pointed to New Zealand's expertise, capabilities and professionalism. As Paul Sinclair, the Head of the Ministry of Defence's International Defence Relations Branch explained:

...[the Chinese] are amazed and take close interest in how we manage to do so much with so little. This comes up at almost every meeting: how we manage so many deployments with such a small force; how economical we are; how we manage with so little funding. They see us as a Western force that is friendly and engaged and has procedures and processes that might well be useful for them to adopt. ${ }^{244}$

In contrast, both the PLA and China's civilian leadership regarded defence diplomacy activities as political undertakings using military means for strategic reasons, rather than as a freestanding set of military initiatives conducted by military professionals for explicitly military reasons. ${ }^{245}$ As a former senior MFAT official made clear:

There are times that people try and divine a value for China that goes beyond that and talk about things like tapping into our expertise in peacekeeping and so on. You don't discount it, but you have to be very careful not to overemphasise it. China doesn't have a defence and security relationship with New Zealand in order to learn from New Zealand. That's not what it's about. If they are going to have a relationship with New Zealand they want to have a defence component of it. ${ }^{246}$

\section{Sino - New Zealand Defence Diplomacy in Practice}

Since exchanging resident defence attachés, China and New Zealand have established mechanisms for regular or irregular consultations on the issues of security, defence and arms control. These include holding annual defence dialogues; bilateral and multilateral committees and working groups to enhance interoperability and implement agreements and arrangements; agreements and arrangements for mutual support; exercises between each nation's armed forces (e.g. the Joint Maritime Search and Rescue Exercise held in

\footnotetext{
${ }^{244}$ Author's interview with Paul Sinclair, 28 November 2012.

${ }^{245}$ Kristen Gunness, "China's Military Diplomacy in an Era of Change” (presented at the National Defense University symposium on China's Global Activism: Implications for U.S. Security Interests, Fort Lesley J. McNair: National Defense University, 2006), 2.

${ }^{246}$ Author's interview with Tony Browne, 11 March 2013.
} 
the Tasman Sea early October $2007^{247}$ ); exchanges of personnel; and mutual participation in training courses and Staff Colleges. The PLA's defence diplomacy activities can be grouped into four broad categories that include strategic-level activities; functional and professional military education exchanges; port calls, and multilateral cooperation.

\section{Strategic exchanges}

Strategic-level activities involve the use of defence diplomacy to shape the international security environment to support Beijing's national defence objectives. The PLA has three basic ways in which it does this: high-level defence consultations and dialogues with key global actors, exchanges between high-level military delegations, and arms transfers.

The NZDF and the PLA have engaged in high-level defence consultations and dialogues and have enjoyed exchanges between high-level military delegations. Exchanges between New Zealand and Chinese high-level military delegations have occurred since 1996. Strategic dialogues between China and New Zealand have been a recent development, with the first such meeting occurring in August 2011. According to John McKinnon, the PLA were "very keen about systemising and structuring relationships. [...] We as a country are not quite so focussed on the formality but we are happy to respond to that." 248

Within strategic level meetings, New Zealand and Chinese defence leaders explored new ways for practical military cooperation and exchanged views on international and regional security. As Paul Sinclair explained:

There is always a discussion of global and regional security interests, of transnational or non-conventional security challenges. So for instance with the PLA: counter-piracy, terrorism, WMD proliferation, and the other key element in all those talks of course is the shape of the bilateral relationship and the future of defence engagement. So they tend to be fairly standard in terms of content. ${ }^{249}$

These meetings invariably end with a pledge to further or enhance military cooperation, not only in personnel exchanges and education, but also to reinforce communication and

\footnotetext{
${ }^{247}$ Bates, Rising Star: China's New Security Diplomacy, 67.

${ }^{248}$ Author's interview with John McKinnon, 7 March 2013.

${ }^{249}$ Author's interview with Paul Sinclair, 28 November 2012.
} 
coordination within multilateral security institutions. Often this is said to "boost the relationship to new highs" or some variation on those same words. ${ }^{250}$ The Chinese see frequent high-level contacts as evidence of the two countries maintaining good momentum in relations. John McKinnon explained that the content of such meetings would vary:

We've certainly had exchanges which have been quite full and reasonably frank with countries like China and Viet Nam where you might expect there to be some reticence. We've had other exchanges with other countries which you could say was fairly banal, perhaps not very revelatory. Sometimes that depends on the personalities; it may not be related to the particular country's perspective on New Zealand, it's just the way that person on the other side of the table might want to operate. Sometimes it is just contingent on what events have occurred in the previous year, or have not occurred - the 'thermometer factor' in the dialogue. ${ }^{251}$

High-level military exchanges between China and New Zealand since 1996 are listed in Table 3.

Table 3: High-Level Defence Exchanges between China and New Zealand since 1996

\begin{tabular}{l|l} 
Date & Delegation \\
\hline May 1996 & $\begin{array}{l}\text { Lieutenant General Xiong Guangkai to New Zealand. } \\
\text { Gerald Hensley, the Secretary of Defence to China. } \\
\text { Chil } 1997 \\
\text { February } 1998 \\
\text { Central Military Commission, to New Zealand. }{ }^{252}\end{array}$ \\
November 1999 1998 & $\begin{array}{l}\text { Max Bradford, Minister of Defence to China. } \\
\text { General Yu Yongbo, Director of PLA General Political Department to New } \\
\text { Zealand. } \\
\text { Major General Maurice Dodson, Chief of General Staff to China. Met with } \\
\text { Chi Haotian. }\end{array}$ \\
December 1999 & $\begin{array}{l}\text { Lt General Liu Shunshun, Commander of PLAAF to New Zealand. } \\
\text { March } 2000\end{array}$
\end{tabular}

\footnotetext{
${ }^{250}$ Xinhua News Agency, "China, New Zealand Pledge to Further Military Cooperation,” China News, December 19, 2012, http://news.xinhuanet.com/english/china/2012-12/19/c_132051487.htm.

${ }^{251}$ Author's interview with John McKinnon, 7 March 2013.

${ }^{252}$ List compiled by cross-referencing Chinese sources including FMPRC and PLA Defence White Papers and NZDF sources including NZDF and MoD Annual Reports.
} 
\begin{tabular}{l|l} 
Date & Delegation \\
\hline
\end{tabular}

October 2000

Air Marshal Carey Adamson, Chief of Defence Force to China. Met with Chi Haotian, Minster of Defence and vice Chairman of Central Military Commission.

November 2000

General Yuan Shoufang, Deputy Director of the PLA General Political Department to New Zealand.

28 March-11 April 2001

General Zhang Wannian, Vice Chairman of the Central Military Commission to New Zealand. Met with PM, Foreign Affairs Minster, acting Minister of Defence, CDF and Secretary of Defence.

September 2001

22-28 September 2001

Graham Fortune, Secretary of Defence to China. Met with General Zhang Wannian and General Xiong Guangkai.

Air Vice Marshal John Hamilton, Chief of Air Force, to China

4-7 November 2001

Mark Burton, Minister of Defence to China. Met with General Chi Haotian, Defence Minister and General Zhang Wannian, Vice Chairman of the Central Military Commission.

April 2002

22-28 May 2005

5-20 September 2005

?-21 September 2006

8-14 October 2006

10-13 November 2006

2007

28 June -6 July 2008

24- 29 November 2008

12-16 March 2009

20 March 2009

18-27 April 2009

22-24 September 2009

Deputy Chief of General Staff to New Zealand.

David Bamfield, Vice Chief of Defence Force to China.

Zhang Qinsheng Deputy Chief of General Staff to New Zealand.

Xu Caihou, vice Chairman of the Central Military Commission to New

Zealand. Met with PM Minister of Defence, CDF and the acting Secretary of Defence.

Lieutenant General Jerry Mateparae, Chief of Defence Force to China.

Phil Goff, the Minister of Defence to China.

1st bilateral Strategic Dialogue

Major General Lou Gardiner, Chief of Army to China

Major General Ma Zhongsheng, Ministry of National Defence Foreign Affairs Office to New Zealand.

Major General Ma Xiaotian to New Zealand (for 2nd bilateral Strategic Dialogue)

Lieutenant General Yand Dongming (PLAAF) to New Zealand.

NZDF Maritime Component Commander to China (for PLAN 60th Anniversary).

NZ Defence Minister Wayne Mapp to China. Met with Liang Guanglie, Defence Minister. 


\begin{tabular}{|c|c|}
\hline Date & Delegation \\
\hline 5-10 November 2009 & Air Vice Marshal Graham Lintott to China (for PLAAF 60th Anniversary). \\
\hline 16-19 May 2010 & $\begin{array}{l}\text { Guo Boxiong, Vice Chairman of the Central Military Commission to New } \\
\text { Zealand. }\end{array}$ \\
\hline 31 May - 3 June 2010 & $\begin{array}{l}\text { Vice Chief of Defence Force, Rear Admiral Jack Steer to China. Met Ma } \\
\text { Xiaotian, Deputy Chief of General Staff PLA. ( } 3^{\text {rd }} \text { bilateral Strategic } \\
\text { Dialogue). }\end{array}$ \\
\hline August 2010 & John McKinnon, Secretary of Defence to China. \\
\hline \multirow[t]{2}{*}{ September 2010} & $\begin{array}{l}\text { Gen Li Jinai, Director General of the PLA General Political Department to } \\
\text { New Zealand. }\end{array}$ \\
\hline & $\begin{array}{l}\text { Rear Admiral Leng Zhenqing, Deputy Chief of Staff PLAN to New Zealand } \\
\text { (during port call). }\end{array}$ \\
\hline October 2010 & $\begin{array}{l}\text { Minister of Defence Wayne Mapp to China (in his capacity as Science } \\
\text { Minister). }\end{array}$ \\
\hline 21-25 November 2010 & $\begin{array}{l}\text { Lieutenant General Chen Yong, Assistant Chief of General Staff to New } \\
\text { Zealand. }\end{array}$ \\
\hline September 2011 & General Hou Shusen, Deputy Chief of General Staff, to New Zealand \\
\hline September 2011 & Lieutenant General Rhys Jones, CDF to Beijing, Nanjing and Shanghai. \\
\hline November 2011 & $\begin{array}{l}\text { Rear Admiral Jack Steer to China. Met General Ma Xiaotian (during } 4^{\text {th }} \\
\text { bilateral Strategic Dialogue). }\end{array}$ \\
\hline April 2012 & $\begin{array}{l}\text { Lieutenant General Qi Jiangou, Assistant Chief of General Staff, to New } \\
\text { Zealand }\end{array}$ \\
\hline November 2012 & $\begin{array}{l}\text { Rear Admiral Jack Steer, Chief of Navy, to China. Met with Qi Jianguo } \\
\text { (during NZDF Staff College visit). }\end{array}$ \\
\hline 16-20 December 2012 & $\begin{array}{l}\text { Major General Tim Keating, Vice Chief of Defence, to China. Met Lieutenant } \\
\text { General Qi Jianguo and Liang Guanglie ( } 5^{\text {th }} \text { bilateral Strategic Dialogue). }\end{array}$ \\
\hline
\end{tabular}

There are also opportunities for high-level meetings on the margins of multilateral meetings. New Zealand Defence Minister Wayne Mapp met with his Chinese counterpart Lian Guanglie at the 2011 Shangri-La Dialogue. ${ }^{253}$

\footnotetext{
${ }^{253}$ Xinhua News Agency, "Chinese Defense Minister Meets New Zealand Counterpart,” June 4, 2011, http://news.xinhuanet.com/english2010/china/2011-06/04/c_13910915.htm.
} 


\section{Functional and educational exchanges}

Like many other armed forces, including New Zealand's, the PLA increasingly took on a wide spectrum of tasks, including traditional military roles as well as non-traditional ones. Like other militaries, while assuming these new roles, the PLA also transformed itself from a large-scale force into one that is smaller, more efficient and technicallyproficient. $^{254}$ Functional and educational exchanges provided PLA officers with firsthand knowledge of foreign militaries that informed decisions about PLA modernisation efforts. Personnel exchanges led to greater knowledge of the other nation's systems and greater understanding of its military and social culture.

Since 2001 New Zealand received several visits from lower ranking PLA officers from PLA units (such as the Second Artillery Force, the Informationisation ${ }^{255}$ Committee, Oil and Quartermaster Department and the Infrastructure and Barracks Department), regional commands (such as Guangzhou Military Area) and defence educational institutions (including the PLA Artillery College, the Xi'an Political College and the National Defence University). During these visits, delegations met their NZDF equivalents to discuss "organisational and capability development." 256 Visits by the commander of the PLA Guangzhou Military Region and the PLAN East Sea fleet to New Zealand (see the section on port calls below) were part of a marked change from previous practice in PLA defence diplomacy in which only much higher-ranked commanders led delegations abroad. ${ }^{257}$ This reflected the PLA's view of these particular visits as largely functional and not strategic, and also met the PLA's goal of having officers outside the General Department learn about foreign militaries first hand. ${ }^{258}$ As the defence relationship developed, functional exchanges increased as interactions and visits took place at lower rank levels. ${ }^{259}$ In June 2007 a visit by a Foreign Affairs Working Group from the Foreign Affairs Office of the Chinese Ministry of National Defence was led by a senior naval captain. The programme included discussions on the Sino-New Zealand military

\footnotetext{
${ }^{254}$ Asia Pacific Centre, "Report from the Conference on Evolving Roles of the Military in the Asia-Pacific" (presented at the Conference on Evolving Roles of the Military in the Asia-Pacific,, Honolulu, Hawaii, 2000), http://www.apcss.org/Publications/Report_Evolving_Roles.html.

${ }^{255}$ A Chinese term equivalent to network enabled or network-centric warfare.

${ }^{256}$ Foreign Affairs, Defence and Trade Committee, "2009/10 Estimates Vote Defence Force (Response to Supplementary Questions 1-27)" (New Zealand Parliamentary Service, June 25, 2009), http://www.parliament.nz/NR/rdonlyres/5C4A4B92-1389-4DC5-97DD04FD2D1E714B/207153/49SCFDT_EVI_00DBSCH_EST_9178_1_A37095_MinisterofDe.pdf. ${ }^{257}$ Allen and McVadon, China's Foreign Military Relations, 5. 
exchange programme, PLAN ship visits to New Zealand and briefings on regional security and defence policy. ${ }^{260}$ In return the PLA hosted a number of visits from NZDF personnel such as Air Commodore Kevin Short in June 2009, who attended a PASOLS meeting and discussed logistics. ${ }^{261}$

Education exchanges were a typical form of defence engagement extended out beyond traditional allies to potential and former adversaries as part of 'new' defence diplomacy. New Zealand regularly offered places to PLA personnel at the NZDF Command and Staff College, dependent on their level of English proficiency. ${ }^{262}$ The College visited China several times, most recently in December 2012, when they were accompanied by the Chief of Navy, Rear Admiral Jack Steer. The first visit took place in September 1998, when students from the RNZAF Command and Staff College (which later became the NZDF Command and Staff College) visited China. ${ }^{263}$ In return, 41 PLA Air Force students from their Campaign Command course visited New Zealand in June 1999 during their overseas study tour. ${ }^{264}$ NZDF students returned to China in August 2002. ${ }^{265}$ The Chinese Ambassador was invited to the NZDF Command and Staff College to speak to the students for the first time in September 2012.

The exchanges also go in the other direction. The PLA's Foreign Languages University in Luoyang hold a position for a NZDF Chinese language student. Language training is an important component of the relationship, and providing Chinese-speaking defence attachés was seen as a way of demonstrating New Zealand's professionalism and commitment to the relationship. ${ }^{266}$

\footnotetext{
${ }^{260}$ Foreign Affairs, Defence and Trade Committee, 2007/08 Financial Review of the New Zealand Defence Force(Response to Questions) (New Zealand Parliamentary Service, 2009), http://www.parliament.nz/NR/rdonlyres/B5B58203-25D5-438C-A58EF0C31AB9EE45/207306/49SCFDT_EVI_00DBSCH_FIN_8721_1_A45787_NewZealandDe.pdf.

${ }^{261}$ Foreign Affairs, Defence and Trade Committee, "2009/10 Financial Review of the New Zealand Defence Force (Question 1.49)" (New Zealand Parliamentary Service, n.d.), http://www.parliament.nz/NR/rdonlyres/6CF16F03-FF67-4A62-A7ED9445908CE9B4/207195/49SCFDT_EVI_00DBSCH_FIN_10188_1_A162886_NewZealand.pdf. ${ }^{262}$ Author's interview with Cdr Shaun Fogarty, 12 December 2012.

${ }^{263}$ Xinhua News Agency, "China-New Zealand Bilateral Relations," China Daily, April 3, 2006, http://www.chinadaily.com.cn/china/2006-04/03/content_558411_5.htm.

${ }^{264}$ Kenneth Allen and Emma Kelly, "Assessing the Growing PLA Air Force Foreign Relations Program," China Brief 12, no. 9 (April 26, 2012): 7, http://www.jamestown.org/uploads/media/cb_04_06.pdf. ${ }^{265}$ Xinhua News Agency, "China-New Zealand Bilateral Relations."

${ }^{266}$ Robert Ayson and Chris Elder, China's Rise and New Zealand's Interests: A Policy Primer for 2030, Discussion Paper 11 (Wellington, N.Z.: Centre for Strategic Studies, 2012), 16.
} 
Military exercises were another manifestation of the expansion of China's defence diplomacy. Since the late 1990's China reversed its policy on exercising with foreign militaries and has undertaken at least 37 exercises and training with a range of different countries. ${ }^{267}$ Combined exercises served several functions; they offered the PLA an opportunity to demonstrate improving capabilities, an opportunity to observe and learn from foreign militaries in an operational environment, and they served as trust-building exercises. $^{268}$ Typically, China exhibited a preference for non-combat exercises over combat-oriented ones. The PLA Navy (PLAN) considered that such exercises had greater practical value by helping them to expand their operations outside home waters and by developing communication abilities with other naval forces. The PLAN and Royal New Zealand Navy (RNZN) participated together in the Joint Maritime Search and Rescue Exercise held in the Tasman Sea early October 2007. China recently began conducting counter-piracy and counter-terrorism exercises with other nations, ${ }^{269}$ presumably for the same reasons. New Zealand, China and Australia held a tri-lateral humanitarian assistance disaster relief exercise, Cooperation Spirit in late October 2012. ${ }^{270}$ Seven NZDF staff attended the exercise for the first time (having only sent an observer in 2010), held in Brisbane with approximately 30 PLA staff and 24 Australian personnel. The NZDF Senior National Officer described the purpose of the exercise as:

The New Zealand Defence Force has a good relationship with our international partners and it's important for us to work closely to build interoperability so we can perform tasks together when required. Participating in exercises like Cooperation Spirit 2012 enables the Defence Force to prepare for a variety of contingencies to ensure that New Zealand can play its part in working with other nations to respond effectively to humanitarian aid and disaster relief events, and contributing to regional peace and stability. ${ }^{271}$

\footnotetext{
${ }^{267}$ Heidi Holz and Kenneth Allen, "Military Exchanges with Chinese Characteristics: The People's Liberation Army Experience with Military Relations," in The PLA at Home and Abroad: Assessing the Operational Capabilities of China's Military, ed. Roy Kamphausen, David Lai, and Andrew Scobell (Carlisle, PA :: Strategic Studies Institute, U.S. Army War College,, 2010), 447.

268 Ibid.

${ }^{269}$ Ibid., 450.

270 "China to Boost Military Talks with Countries," China Daily, October 31, 2012, http://eng.mod.gov.cn/DefenseNews/2012-10/31/content_409957.htm.

${ }^{271}$ New Zealand Defence Force, "NZ, China and Australia Link for Disaster Response Planning," Press Releases, October 28, 2012, http://www.nzdf.mil.nz/news/media-releases/2012/20121029-ncaalfd.htm.
} 


\section{Port calls}

Port calls or visits by naval ships occupy a special place in Chinese defence diplomacy, with PLAN visits abroad often receiving considerable publicity in the Chinese press. ${ }^{272}$ Chinese publicity about the 40 year anniversary of Sino - New Zealand diplomatic relations featured port calls between the two nations heavily. ${ }^{273}$ This was significant as for some time the PLAN rarely ventured beyond Chinese territorial waters. Between 1979 and 1987 China received port calls from 33 foreign warships, yet its own first foreign port call was not until $1985 .^{274}$ The visit by two New Zealand frigates to Shanghai in 1987 was a relatively early move in this respect.

The value China placed on the expansion of defence diplomacy in the 1990s was illustrated by the 1997 Pacific voyages of two guide missile destroyers, at the time the only relatively capable and modern warships the PLAN had. ${ }^{275}$ The first visit by the PLAN to New Zealand took place shortly after this in April 1998, when two ships, the Qingdao and Shichang, made a port call to Auckland. ${ }^{276}$ The Royal New Zealand Navy made a reciprocal visit the following year. Following these initial exchanges, port calls have been a regular feature of defence diplomacy between the two countries, as follows:

Table 4: Port calls conducted by China and New Zealand $1996-2012^{277}$

Date

April 1998

October 1998

October 2001

27-30 September 2002

\section{Details}

Qingdao and Shichang visited Auckland.

HMNZS Wellington and HMNZS Endeavour visited Qingdao, the headquarters of the PLAN North Sea fleet.

Yichang and Taichang visited Auckland.

HMNZS Te Kaha visited Shanghai.

\footnotetext{
${ }^{272}$ Kamphausen, Lai, and Scobell, The PLA at Home and Abroad Assessing the Operational Capabilities of China's Military, 445.

${ }^{273}$ People's Republic of China, 16 January 2013, 'Pragmatic Cooperation' in Documentary Picture Exhibition in Commemoration of the 40th Anniversary of the Establishment of Diplomatic Relations between China and New Zealand, http://www.chinaembassy.org.nz/eng/xxl/sn40y/P020130116215005277822.doc

${ }^{274}$ Kamphausen, Lai, and Scobell, The PLA at Home and Abroad Assessing the Operational Capabilities of China's Military, 446.

${ }^{275}$ Allen and McVadon, China's Foreign Military Relations, 48.

${ }^{276}$ PRC Ministry of Foreign Affairs, "China and New Zealand Relations 2009," China Daily, accessed March 23, 2012, http://www.chinadaily.com.cn/hellochina/newzealandambassador2009/200908/21/content_8598670.htm.

${ }^{277}$ List compiled using Chinese sources including FMPRC and PLA Defence White Papers and NZDF sources including NZDF and MoD Annual Reports.
} 


\begin{tabular}{|c|c|}
\hline Date & Details \\
\hline $17-21$ June 2005 & HMNZS Te Mana and HMNZS Endeavour to Shanghai. \\
\hline 7 - 10 October 2007 & Haerbin and Hongzehu visited Auckland. \\
\hline $11-22$ October 2007 & HMNZS Te Kaha visited Shanghai. \\
\hline April 2009 & $\begin{array}{l}\text { HMNZS Te Mana and Endeavour visited Qingdao for PLAN } 60^{\text {th }} \\
\text { Anniversary }\end{array}$ \\
\hline 16-19 May 2010 & HMNZS Te Kaha visited Shanghai. \\
\hline $11-15$ September 2010 & Training ship Zhenghe and frigate Mianyang visit New Zealand. \\
\hline 27 June 2011 & HMNZS Te Mana scheduled to visit Shanghai (cancelled) \\
\hline 5-14 May 2013 & HMNZ Te Mana visited Shanghai \\
\hline
\end{tabular}

Visits to distant ports provided navies with practice in the seamanship and logistics required to undertake long-distance deployments. China analysts who viewed defence diplomacy activities primarily as a means of making the PLA a more formidable fighting force regarded these port calls as a means of developing PLAN 'blue-water' or open ocean capabilities. ${ }^{278}$ Other analysts however pointed out that China's tentative steps were very different from carrying out major sustained naval deployments like those the United States Navy is capable of. ${ }^{279}$ The fact that the New Zealand could reciprocate with port calls to China highlighted the high-level of capability and seamanship enjoyed by the RNZN and demonstrated that the PLAN has many valuable skills to learn from the RNZN. The schedule of visits by Navy ships to China underlines their significance. As HMNZS Te Mana's commanding officer pointed out during a port call to Shanghai in 2007, "considering New Zealand has only two frigates that really do the bulk of this type of engagement, to say that in two years we'll be back, that's big. There's no doubt New Zealand is wishing to grow its relationship with China." 280

\footnotetext{
${ }^{278}$ Kamphausen, Lai, and Scobell, The PLA at Home and Abroad Assessing the Operational Capabilities of China's Military, 30.

${ }^{279}$ Allen and McVadon, China's Foreign Military Relations, 12.

${ }^{280}$ Palmer, "Flying the New Zealand Flag in China."
} 
During a 2007 visit, RNZN bands played ashore and an open day was held. Sports and cultural events took place while the crew engaged in some sightseeing. ${ }^{281}$ On the occasion of the fourth visit by PLAN ships to New Zealand in September 2010, two RNZN officer cadets were invited to train aboard with PLAN cadets; the first time naval officers from a Western country were invited to do so (although two Royal Australian Navy midshipmen were also present). ${ }^{282}$ Then Defence Minister Wayne Mapp remarked:

That's an important gesture. The naval visit continues a pattern of improved dialogue between our nations. This fits as part and parcel as China's reaching out to the broader Asia Pacific community. ${ }^{283}$

On leaving, the Chinese staged a position-keeping exercise by practising naval formations with HMNZS Wellington. ${ }^{284}$ Such short exercises were common. As a RNZN officer noted during an earlier visit, "it's not a big deal in terms of how complex it is or how difficult it is for us to do, but it is a big deal in our growing relationship with them. It's another little advance in the relationship." 285

\section{Multilateral cooperation}

New Zealand and China participated in several common multilateral security cooperation activities, including the ASEAN Post-Ministerial Conference (foreign ministers), the ASEAN Regional Forum (foreign ministers), the East Asia Summit, the Shangri-La Dialogue, and the Council for Security Cooperation in the Asia Pacific (a track II nongovernmental forum). ${ }^{286}$ China has also begun to engage in multilateral defence forums such as the Pacific Armies Management Seminar (PAMS), Western Pacific Naval Symposium (WPNS), and the Pacific Armies Senior Officers Logistics Seminar (PASOLS). Inaugurated in 1999, the Pacific Armies Chiefs Conference (PACC) was first

\footnotetext{
${ }^{281}$ New Zealand Defence Force, “People's Liberation Army Navy Visits NZ,” October 8, 2007, www.scoop.co.nz/stories/PO0710/S00088.htm.

${ }^{282}$ Fuseworks Media, "Chinese Ships to Visit Auckland," September 10, 2010, http://www.voxy.co.nz/national/chinese-ships-visit-auckland/5/62657.

${ }^{283}$ CCTV News, CCTV Exclusive Interview with NZ Defense Minister, 2010, http://english.cntv.cn/program/newsupdate/20100913/101049.shtml.

${ }^{284}$ Yang Biao and Deng Youbiao, "Chinese and New Zealand Warships Carry Out Joint Maneuver Exercise," PRC Ministry of National Defense, September 16, 2010, http://eng.mod.gov.cn/MilitaryExercises/2010-09/16/content_4194059.htm.

${ }^{285}$ Palmer, "Flying the New Zealand Flag in China."

${ }^{286}$ New Zealand Ministry of Foreign Affairs and Trade, Our Future with Asia, 72.
} 
patronised by China in $2011^{287}$ and New Zealand is hosting a combined PACC/PAMs later in 2013. All of these forums evolved from older patterns of defence diplomacy; originally initiated to progress interoperability between key states within the region. Over time, new partners such as China were invited to participate. For example, PASOLS was first convened in 1971 with the purpose of developing formal arrangements for the provision of reciprocal logistics support between nations during coalition operations, humanitarian assistance disaster relief and United Nations operations. The first participants were Taiwan, Indonesia, the Khmer Republic, Korea, Philippines, Singapore, Thailand, United States and South Viet Nam. New Zealand joined in 1984, and China in 1995. Lower-ranked senior officers attend these types of meetings, such as the NZDF Brigadier who attended the September 2009 PASOLS meeting in China.

As pointed out in Chapter Three, much of this multilateral cooperation took place around topics such as military roles in peacekeeping or humanitarian assistance and disaster relief. Such topics were both non-threatening for former and potential adversaries and assuage concerns around the potential for core war-fighting capabilities to be compromised. For example, the theme of the 2011 PACC, which China attended for the first time, was Building Land Forces ' Capacity through Multilateral Security Cooperation. ${ }^{288}$

\section{Issues in Sino - New Zealand Defence Diplomacy}

The NZDF is quite happy to engage with the PLA, particularly as our size difference eliminates us as a potential threat, and offers China an opportunity to 'practice' engagement with a Western nation, effectively mitigating risk to their potential relationships with larger Western powers, most notably the United States. Similar sentiment is seen in other aspects of the wider Sino-New Zealand relationship, such as China's first Free Trade Agreement concluded in 2008. This also reflects a broader recognition of New Zealand's importance as an example of a Western nation responding

\footnotetext{
${ }^{287}$ PASOLS Secretariat, "Pacific Area Senior Officer Logistics Seminar Brochure" (United States Pacific Command), Annex A, accessed November 11, 2011, http://www.docstoc.com/docs/35977312/PACIFICAREA-SENIOR-OFFICER-LOGISTICS-SEMINAR-BROCHURE.

${ }^{288}$ Jermyn Chow, "Army Chiefs Here For Security Talks: China and Laos Taking Part for First Time Since Defence Summit Began in 1999," Singapore Straits Times, July 29, 2011, sec. B10.
} 
to China's rise. ${ }^{289}$ Neither China nor New Zealand has to worry about misperceptions and miscalculations about the other's intentions and capabilities.

\section{Conditionality}

One of the dilemmas Cottey and Forster recognised was how far should defence diplomacy be tied a partner's cooperation or progress on other issues and its domestic policies? Known as conditionality, this dilemma has presented issues for a number of countries and is a persistent feature of debates on the use of defence diplomacy. Civilian control of the military does not appear to be an issue that impacts on NZDF - PLA relations. Over time, the combined effect of professionalism and international contact has somewhat de-emphasised the ideological outlook of the PLA. ${ }^{290}$ New Zealand and China have some fundamental differences in terms of their values, beliefs and political systems, which both parties openly acknowledge. ${ }^{291}$ When defence links were first being explored in the mid 1990s, Gerald Hensley explained that:

...we were past that stage. The Deng Xiaoping era had changed all that. Plus the obvious fact that in 10,20, 30 years China would be a dominant influence in the region along with the United States and Japan. So there was no concern about Communism, which was distinctly fading in China itself as a motivating force. It was just common sense; that the region was changing and we needed to adapt. ${ }^{292}$

When questioned about how New Zealand deals approaches dealing with China, the former Secretary of Defence, John McKinnon, pointed out:

You know this is a single-party... Communist state. You know the military exists within a different framework from the way the military operates here [in New Zealand]. That's part of the reason why you want to talk to them, because

\footnotetext{
${ }^{289}$ Comment made by Zhang Yunling, Director of the Academic Division of International Studies, National Institute of International Affairs (CASS) at the Symposium on the $40^{\text {th }}$ Anniversary of the Establishment of New Zealand- China Diplomatic Relations http://www.victoria.ac.nz/chinaresearchcentre/programmes/symposium/40th-Anniversary-Symposium-inBeijing.html (Accessed 03 March 2013)

${ }^{290} \mathrm{~N} \mathrm{Li}$, Chinese Civil-Military Relations in the Post-Deng Era: Implications for Crisis Management and Naval Modernization, China Maritime Studies 4 (Newport, R.I.: United States Naval War College, 2010), 5.

${ }^{291}$ Yongjin Zhang, "Relationship Dynamics and Strategic Calculus: A Chinese Perspective," in China and New Zealand: A Thriving Relationship Thirty Years On, ed. James Kember and Paul Clark (Auckland, N.Z.: New Zealand Asia Institute, University of Auckland, 2003), 97.

${ }^{292}$ Author's interview with Gerald Hensley, 22 March 2013.
} 
you know you are going to be operating across different premises and constructs. ${ }^{293}$

Other officials were more emphatic:

...we don't have any concerns about that because we have been operating in that framework since 1972. When you build a relationship with China you do it very much within that context. That's the nature of the party at the other end of the relationship. [...] Diplomacy is conducted between states and that is the nature of that state. We don't refuse to engage with China out of any approval or disapproval of the nature of their government. [...] That's just the basis on how we deal with China. It's not a point upon which we engage in discussion. ${ }^{294}$

Human rights are a perennial issue, but a number of New Zealand foreign officials explained that while they are a factor, such issues are pursued and New Zealand's views stated through different channels to the defence relationship. Tony Browne added "nothing is completely separate. Many different parts of the relationship are the subject of a sector-specific dialogue. [...] You're talking to different people, on different issues." ${ }^{295}$

\section{Prospects for Sino NZ defence relations}

The NZDF still has a modest relationship with China, one that has been described as "appropriate to the circumstances." 296 Commentators have said that there is scope for New Zealand to build on initial contacts to achieve a greater understanding of China's military objectives and what challenge they may pose to countries in the Western Pacific. ${ }^{297}$ It is clear from discussions with senior officials that New Zealand will continue to invest in defence and other activities in order to contribute to an enduring political relationship with China. ${ }^{298}$ For China, worthwhile bilateral relationships must have substance beyond the purely commercial. ${ }^{299}$ It has been said elsewhere that the defence relationship should not be judged on any single visit, but rather on the sum of all

\footnotetext{
293 Author's interview with John McKinnon, 7 March 2013.

${ }^{294}$ Author's interview with Tony Browne, 11 March 2013.

295 Ibid.

296 Author's interview with John McKinnon, 7 March 2013.

${ }^{297}$ Ayson and Elder, China's Rise and New Zealand's Interests: A Policy Primer for 2030, 14.

${ }^{298}$ Presentation by Grahame Morton, Ministry of Foreign Affairs and Trade, during the 'New Zealand, Australia and China's Rise' Symposium. Victoria University of Wellington, 7 April 2011.

${ }^{299}$ Ayson and Elder, China's Rise and New Zealand's Interests: A Policy Primer for 2030, 16.
} 
visits. ${ }^{300}$ Indeed, John McKinnon described New Zealand's defence diplomacy with China as "a cumulative game." 301

It is difficult however to see how the relationship might be maintained and strengthened. There certainly are prospects in terms of the types of interaction between the two countries. Issues such as counter-terrorism, cyber warfare, Antarctic resource protection, maritime surveillance and disaster relief in South Pacific stand out as possible avenues where New Zealand could broaden cooperation, particularly in terms of Chinese armed forces structure and their evolving missions. Former Defence Minister Dr Wayne Mapp considered that the relationship needed more thought put into it and foresaw the conduct of combat-oriented exercises. ${ }^{302}$ However, further steps in traditional relationships typically include things like technology transfer and intelligence sharing, which New Zealand is unlikely to be able to follow through with China on due to our place within the 'five-eyes' community. ${ }^{303}$ Resources are likely to be the biggest limiting factor. As former Secretary of Defence John McKinnon pointed out:

Our difficulty is just a sheer numbers. We will probably continue to send ships to visit Chinese ports but we won't be sending them at a higher rate because we just don't have that capability. We have a range of dialogues; I don't think we'll want to have too many more, we don't have the numbers of staff to do it. The limit is not about what we could do but what we have the resources to do. Clearly that doesn't apply on the Chinese side in the same way. They are mindful of where our limits are. ${ }^{304}$

\section{Conclusion}

The Sino-New Zealand defence relationship developed well before the concept of defence diplomacy was formally advanced. Initial moves in the relationship occurred in 1995, well before the United Kingdom Strategic Defence Review was released in 1998.

Despite this, New Zealand defence officials had a clear sense of the connection between defence and broader foreign policy goals at the time, as evidenced by Gerald Hensley's use of the term "security diplomacy." The China example proves that New Zealand was

\footnotetext{
${ }^{300}$ Allen and McVadon, China's Foreign Military Relations, 74.

301 Author's interview with John McKinnon, 7 March 2013.

${ }^{302}$ Author's interview with Dr Wayne Mapp, 14 March 2013.

${ }^{303}$ Five eyes consists of the United States, the United Kingdom, Canada, Australia and New Zealand.

${ }^{304}$ Author's interview with John McKinnon, 7 March 2013.
} 
conducting defence diplomacy well before it was identified and further defined by Cottey and Forster.

Both sides regularly point out that the Sino-New Zealand relationship has had many 'firsts'. It is important to note that the status of China's relationship with New Zealand is based upon the Chinese level of comfort with New Zealand. From the Chinese perspective, if they can get it right with New Zealand, they can go on and achieve the same goals with other Western nations.

New Zealand's defence relationship must be considered in light of the broader political and economic relationship with China. The defence relationship mirrors the wider political relationship. This relationship is characterised by regular high-level contacts, including a widening range of dialogues, and thus defence relations have also seen an increase in high-level contacts and the establishment of bilateral strategic dialogues. Almost all of China's top Politburo members have visited New Zealand. In that context, it is not unusual then to have seen an increase in senior Defence exchanges to the point that they are occurring on an almost monthly basis.

The NZDF believes China's interest in defence relations is based on what China can learn from the NZDF in terms of military reform and capabilities such as logistics and administration. The NZDF, while small, is a modern and professional Western military force in the same model as the United Kingdom, United States and Australia, and the PLA can learn much about civilianisation of defence activities, training, force modernisation, and the employment of non-commissioned officers for example. From a foreign policy perspective, the defence relationship is one part of New Zealand Inc's long-term engagement of China. Defence ties generate goodwill and are one component among many that comprise a comprehensive bilateral relationship.

Sino - New Zealand defence relations do not fit neatly into the model of 'new' defence diplomacy put forward by Cottey and Forster. Instead of the NZDF as a 'Western' military reaching out to its former foe the PLA, the development of military relations between the two countries has taken place within the context of the PLA's own expansion of defence relationships throughout the region and the wider world. 


\section{CHAPTER FIVE New Zealand's Defence Relations with Viet Nam}

\section{Introduction and the development of Viet Nam - New Zealand Relations}

New Zealand's defence relationship with the Viet Nam People's Army (VPA) is a key example of New Zealand's burgeoning defence diplomacy with a former enemy. In the new strategic environment following the Cold War featuring the rise of China and the development of transnational security threats, Viet Nam has gone from the embodiment of the 'Domino Theory' of communist aggression to a nation with demonstrated common security interests with New Zealand. Viet Nam has entered dialogue with New Zealand in a wide variety of multinational forums such as various ASEAN bodies, the Proliferation Security Initiative, and most recently, the Trans Pacific Partnership. ${ }^{305}$ Defence engagement with Viet Nam is particularly poignant considering New Zealand's contribution to the Viet Nam War.

Indochina played a significant role in New Zealand's national security calculus following the end of the Second World War and the adjustment to new strategic realities. The 1950-1953 Korean War reinforced New Zealand's bipartisan commitment to the Western camp in the Cold War and brought a heightened sensitivity to the communist threat to regional stability. New Zealand's military involvement in Viet Nam was seen as a way of maintaining the United States security guarantee. ${ }^{306}$ New Zealand troops fought the VPA in South Viet Nam between 1965 and 1972, losing 37 service members. ${ }^{307}$

The same Labour Government that initiated diplomatic relations with the People's Republic of China in 1972 also withdrew the last New Zealand troops from Viet Nam that same year. Following the withdrawal, New Zealand maintained only peripheral interest in the continued conflict between North and South Viet Nam. Viet Nam continued to play a role in defining New Zealand's perspective on international security through the

\footnotetext{
${ }^{305}$ Centre for Strategic Studies New Zealand, Projecting Our Voice: Major Power Relationships in Asia, the Responses of Regional Organisations and the Implications for New Zealand. (Wellington, N.Z.: Centre for Strategic Studies, 2011), 15, http://www.victoria.ac.nz/css/docs/CSCAP\%20national\%20study/CSCAP\%20National\%20Study\%20Sep $\% 202011$.pdf.

${ }^{306}$ Roberto Rabel, New Zealand and the Viet Nam War: Politics and Diplomacy (Auckland, N.Z.: Auckland University Press, 2005), 5.

${ }^{307}$ Ian McGibbon, "The Defence Dimension," in Southeast Asia and New Zealand: A History of Regional and Bilateral Relations, ed. Anthony L. Smith (Singapore: Institute of Southeast Asian Studies, 2005), 23.
} 
1980s. Viet Nam's invasion of Cambodia in 1978 and the Soviet expansion of the Cam Ranh Bay naval base were both identified in New Zealand's 1983 Defence Review as indicators of a deteriorating international security situation. ${ }^{308}$

Within Viet Nam itself, the situation was changing. Viet Nam's economic performance struggled after 1975 and as a result, the Communist Party of Viet Nam launched a massive programme of economic change, beginning with the adoption of the reform policy named doi moi, or renovation. In May 1988, the Vietnamese government resolved to reorient its foreign trade away from the communist bloc towards the Asia Pacific and capitalist world and undertook what it termed a "multi-directional foreign policy orientation." 309 Viet Nam's improved economic position continued to play an indirect role in military reforms, and was a significant driver of the VPA's force modernisation, characterised by reductions in its large standing ground force together with enhancement of the navy and air force.

In 1991, the collapse of the Soviet Union left Viet Nam without a formal ally. The challenge then became how to develop relations with former foes and new multilateral institutions to bolster national security. A priority was to mend its strained relations with China, damaged by Viet Nam's invasion of Cambodia in 1978, the signing of its Treaty of Friendship and Cooperation with the Soviet Union, and their border conflict in $1979 .{ }^{310}$ Viet Nam fully normalised diplomatic relations with China in 1991.

Since then, Viet Nam has become increasingly strategically significant. Its situation as a littoral state in the South China Sea puts it in an area of contested resource claims and potential conflict. It is an emerging middle income country with significant trade potential for New Zealand. It has been undergoing gradual defence modernisation and is transforming from a ground-force oriented defensive power to one with increasing maritime projection capabilities. Since joining the ASEAN Regional Forum as an

\footnotetext{
${ }^{308}$ New Zealand Ministry of Defence, Defence Review 1983 (Wellington, N.Z.: Government Printer, 1983), 9.

${ }^{309}$ Carlyle Thayer, "Vietnam's Defence Diplomacy and Its Impact on Foreign Relations" (presented at the Euro Viet 6, Hamburg, Germany: Asien-Afrika Institut, Universitat Hamburg, 2008), 2, http://www.scribd.com/intasma/d/16447618-Carlyle-Thayer-Vietnams-Defence-Diplomacy-and-Its-Impacton-Foreign-Policy.

${ }^{310}$ Bruce Elleman, "Sino-Soviet Relations and the February 1979 Sino-Vietnamese Conflict" (presented at the 1996 Vietnam Symposium "After the Cold War: Reassessing Vietnam,” Lubbock, Texas: The Vietnam Center and Archive, 1996), http://www.vietnam.ttu.edu/events/1996_Symposium/96papers/elleviet.htm.
} 
observer in 1994, Viet Nam has become a key player both in this forum and other regional security institutions, and it is recognised as an emerging strategic partner of the United States. ${ }^{311}$ China's rise and its challenge to United States primacy present the most pressing security challenge for Viet Nam. It has therefore sought to develop defence ties with all the major powers including the United States, Russia, Britain, France as well as China. ${ }^{312}$ It has also developed relations with a range of smaller states in the region including New Zealand.

\section{The Development of New Zealand's Defence Diplomacy with Viet Nam}

Prior to 1994, Viet Nam was internationally isolated, ${ }^{313}$ but since this time there has been a steady rise in the number of foreign high-level defence delegations visiting the country. ${ }^{314}$ This expansion of defence diplomacy took place within a changed strategic context that included the easing of regional tensions, particularly along the SinoVietnamese border; the withdrawal of Vietnamese troops from Cambodia; a new emphasis on economic development and regional co-operation; and the loss of economic and military aid from Moscow.

Viet Nam recognised the broader utility of its armed forces in foreign policy at an early stage. Its first Defence White Paper, released in 1998, made international cooperation one of seven 'key measures' for the VPA. ${ }^{315}$ Commenting on the White Paper, the Vietnamese Deputy Minister of National Defence advocated the expansion of defence relations with other countries, specifically China, Japan and the United States, which would also enhance Vietnam's broader political, economic and diplomatic relations with these countries. $^{316}$ New Zealand opened an embassy in Ha Noi in 1995 but it was not until 2001 that the New Zealand Defence Attaché based in Bangkok was accredited to Viet Nam, marking the formalisation of defence links. The defence relationship had modest beginnings, with small scale support and training for the purposes of capacity building, conducted under the auspices of NZDF's Mutual Assistance Programme. In the

\footnotetext{
${ }^{311}$ Carlyle Thayer, "The Outlook for US-Vietnam Relations: Presentation to East-West Center, Washington D.C.," March 23, 2011, http://www.scribd.com/doc/51880102/Thayer-US-Vietnam-Defence-Relations.

${ }_{312}$ Carlyle Thayer, "Vietnam's Security Outlook: Presentation to International Workshop of Asia-Pacific Security. National Institute of Defence Studies, Tokyo, Japan,” January 17, 2012, http://www.scribd.com/doc/78512624/Thayer-Vietnam\%E2\%80\%99s-Security-Outlook.

${ }^{313}$ Thayer, "Vietnam's Defence Diplomacy and Its Impact on Foreign Relations."

${ }^{314}$ Ibid.

315 "Vietnam's Defence White Paper," Southeast Asian Affairs (1999): n/a.

${ }^{316}$ Ibid.
} 
early 2000s the VPA began making tentative steps in further developing its defence diplomacy activities, mainly with high-level military exchanges with neighbours. ${ }^{317}$ The first high-level exchange between the VPA and the NZDF occurred in 2004 when the New Zealand Chief of Army, Major General Jerry Mateparae visited Viet Nam. A senior MFAT official put the VPA's motivations into perspective, stating "the Vietnamese would have pushed the high-level contacts very strongly, because they do it in other aspects of the relationship." 318

Viet Nam's recent defence diplomacy efforts should be seen in the context of Viet Nam's wider engagement with the world, including joining the World Trade Organisation in $2007,{ }^{319}$ gaining a non-permanent seat at the United Nations Security Council in 2008, and moves towards contributing troops to United Nations peacekeeping operations.

Much of the focus of policy analysis on Viet Nam's defence diplomacy activities revolved around relations between the Viet Nam People's Army and the United States military. Military relations between the United States and Viet Nam were normalised in 1996, but they continued to be hampered by the hangover of the Vietnam War. Legacy issues included prisoners of war and the remains of missing personnel on the United States military side, while the Vietnamese military brought up the effects of Agent Orange and alleged United States Government support to anti-regime organisations, along with more general suspicions about United States motives. ${ }^{320}$ Typically, the areas of defence cooperation between the two countries have been limited to areas of little controversy; peacekeeping, environmental security, search and rescue and disaster response. ${ }^{321}$ This focus on the United States has largely obscured the significant progress made by Viet Nam in its relations with other Western nations such as New Zealand.

\footnotetext{
${ }^{317}$ Robert Karniol, “Country Briefing: Vietnam - Off the Ground,” Jane's Defence Weekly, January 4, 2006.

${ }^{318}$ Author's interview with senior MFAT official, 15 February 2013.

${ }^{319}$ World Trade Organisation, "WTO | Accession Status: Viet Nam," 2012, http://www.wto.org/english/thewto_e/acc_e/a1_vietnam_e.htm.

${ }^{320}$ Lewis M. Stern, US-Vietnam Defense Relations: Deepening Ties, Adding Relevance, INSS CSR Strategic Forum (Washington D.C.: Institute for National Strategic Studies, 2009), 2, http://kms1.isn.ethz.ch/serviceengine/Files/ISN/121075/ipublicationdocument_singledocument/5b3046527017-4db7-898a-e70fa22e8fe1/en/SF246.pdf.

${ }^{321}$ Ibid.
} 
In May 2005, Vietnamese President Phan Van Khai concluded his first visit to Wellington with the signing of a Declaration of Cooperation that established a framework for developing bilateral relationships in a number of areas including defence. The Declaration explained the aims of security cooperation were to "enhance mutual trust and understanding, build bilateral cooperation [and] strengthen cooperation in countering terrorism."322

In 2009, the Vietnamese General Secretary Nong Duc Manh visited New Zealand and issued a joint statement with New Zealand Prime Minister John Key in which they agreed to establish a bilateral Comprehensive Partnership to update and extend the 2005 Declaration. $^{323}$ The Comprehensive Partnership paved the way for regular bilateral defence dialogues between the two countries on issues including counter-terrorism, maritime security and peacekeeping operations.

The relationship progressed further in 2010, when New Zealand Foreign Minister Murray McCully visited Viet Nam in July. The Foreign Ministers of the two countries signed the New Zealand Viet Nam Action Plan 2010-2013 to give effect to the Comprehensive Partnership. The Action Plan sets out a range of initiatives including defence cooperation. Specifically, the two parties agreed:

- To exchange high-level military visits;

- To hold annual Defence Policy Talks;

- To continue to provide assistance to the Vietnamese military through the New Zealand Mutual Assistance Programme with a particular focus on English language training, military training design and techniques, engineer training and command and leadership skills for Vietnamese officers.

- To exchange information and experience on United Nations peacekeeping operations; and

- $\quad$ To consider the offer by Viet Nam for New Zealand military personnel to study Vietnamese in the Academy of Military Technology. ${ }^{324}$

\footnotetext{
322 “Text: Joint Declaration of Cooperation Between NZ and Viet Nam,” National Business Review (May 9 , 2005), http://www.nbr.co.nz/article/text-joint-declaration-cooperation-between-nz-and-viet-nam.

${ }^{323}$ New Zealand Embassy Ha Noi, "Viet Nam and New Zealand Release Joint Statement at End of Visit September 2009," September 12, 2009, http://www.nzembassy.com/viet-nam/news/viet-nam-and-newzealand-release-joint-statement-at-end-of-visit-september-2009.

${ }^{324}$ New Zealand Ministry of Foreign Affairs and Trade, "New Zealand - Viet Nam Action Plan 20102013," July 21, 2010.
} 
A new Action Plan was due to be agreed between the end of 2013 and the start of 2014. It was expected that the second Action Plan would be more focussed on specific areas, but in terms of defence it was likely to be a continuation of current activity. ${ }^{325}$

\section{Purposes of Viet Nam - New Zealand Defence Diplomacy}

Viet Nam's second Defence White Paper, released in 2004, explained that the establishment and promotion of relations of exchange and cooperation with the armed forces of other countries was "in the interests of consolidating peace and in the consistent implementation of the foreign policy of independence, sovereignty, door-opening, multilateralisation and diversification of external relations..." 326 Purposes such as conflict prevention were a lower priority.

For Viet Nam, the defence relationship with New Zealand became an expression of its growing regional profile and reflected its growing influence in the region. As a senior foreign affairs official explained:

The Vietnamese [...] attach a lot of importance to being able to point to these sorts of relationships and being able to demonstrate that it is being taken seriously internationally. Over the years that has certainly been a big driver. It was about their own mana. ${ }^{327}$

Less strategically, the Viet Nam Ministry of National Defence saw defence relationships as opportunities for the development of the VPA. Two broad rationales behind Viet Nam's defence engagement can be discerned from reading Viet Nam's Defence White Papers. The first is the development of the VPA through cooperation and research into the military art, science and technology, with the VPA particularly keen to modernise its command and control systems. The second is to bolster its domestic arms industry. Viet Nam's defence diplomacy is geared towards force modernisation in terms of both structures and equipment. This has driven Viet Nam to reach out to both its traditional suppliers such as Russia, but also to extend defence cooperation with the UK, France, and

\footnotetext{
${ }^{325}$ Author's interview with senior MFAT official, 15 February 2013.

${ }^{326}$ Socialist Republic of Viet Nam Ministry of National Defence, Vietnam's National Defense in the Early Years of the 21st Century (Ha Noi: Ministry of National Defense, 2004), 69-70.

${ }^{327}$ Author's interview with senior MFAT official, 15 February 2013.
} 
India. The priorities for these external defence relationships are training, education and academic exchanges. ${ }^{328}$

The VPA considered that its military diplomacy provided other countries with an understanding of Viet Nam's national defence policies, which contributed to the overall peace and security of the region and the wider world. ${ }^{329}$ Viet Nam's military diplomacy activities included academic exchanges, military exchanges, participation in regional seminars, conferences and workshops, ship visits and participation in multinational activities and exercises including humanitarian assistance and disaster relief, anti-piracy, anti drug trafficking patrols and maritime search and rescue. New Zealand's defence diplomacy activities with Viet Nam can be grouped into four broad categories; high-level exchanges, professional military education exchanges, port calls and multilateral cooperation.

\section{Strategic Exchanges}

The relationship has evolved into new areas including annual bilateral talks. ${ }^{330}$ Before looking at high-level exchanges, it should be acknowledged that the VPA describes exchanges at the deputy-ministerial level as Logistics, reflecting Vietnamese organisational practice by which the head of the VPA General Logistics Department is also the deputy minister of National Defence. Thus, foreign delegations received by the deputy minister are also placed in the Logistics category. ${ }^{331}$ High-level military exchanges between Viet Nam and New Zealand between 2001 and 2013 are listed in Table 5.

Table 5: High Level Defence Exchanges between New Zealand and Viet Nam ${ }^{332}$

\begin{tabular}{l|l} 
Date & Delegation
\end{tabular}

2004 Major General Jerry Mateparae Chief of Army to Viet Nam

November 2006 Phil Goff, Defence Minister to Viet Nam

\footnotetext{
${ }^{328}$ Socialist Republic of Viet Nam Ministry of National Defence, Vietnam National Defence (Ha Noi: Ministry of National Defence, 2009), 98.

${ }^{329}$ Socialist Republic of Viet Nam Ministry of National Defence, Vietnam's National Defense in the Early Years of the 21st Century, 72.

${ }^{330}$ Author's interview with senior MFAT official, 15 February 2013.

331 Thayer, "Vietnam's Defence Diplomacy and Its Impact on Foreign Relations."

${ }^{332}$ Compiled from New Zealand Ministry of Foreign Affairs and Trade, Viet Nam Ministry of National Defense, and New Zealand Defence Force sources.
} 


\section{\begin{tabular}{l|l} 
Date & Delegation
\end{tabular}}

Early 2007

Senior Lieutenant General Nguyen Huy Hieu, Vice Defence Minister to New Zealand

22-27 September 2007

Paul Sinclair, Head of IDR Branch to Viet Nam (for defence policy talks)

August 2008

25-29 July 2009

1-11 March 2010

Mid - March 2010

Lieutenant General Jerry Mateparae Chief of Defence to Viet Nam

Brigadier Phil Gibbons to Viet Nam (for bilateral defence talks)

Major General Rhys Jones, Chief of Army to Viet Nam

Lieutenant General Nguyen Chi Vinh, Vice Minister of Defence to New Zealand

Mid - 2010

10-16 October 2010

Air Commodore Kevin Short to Viet Nam (for bilateral defence talks)

Wayne Mapp, Defence Minister to Viet Nam (for the first $\mathrm{ADMM}+)$

July 2011

Unknown (Viet Nam officials to New Zealand for first bilateral talks)

20 -23 September 2012

Chief of Navy to Viet Nam*

25-26 September 2012

Defence Talks in Ha Noi

11- 14 November 2012

Nguyen Chi Vinh, Deputy Minister of Defence to New Zealand.

22-25 March 2013

Phung Quang Thanh, Minister of National Defence to New Zealand.

*this visit occurred during the naval port call described in more detail in the section below.

Annual bilateral defence talks have taken place since the first in July 2011 held in Wellington New Zealand. ${ }^{333}$ The second was held in Ha Noi in September 2012, while the third occurred in March 2013. These talks have not yet progressed to a 'strategic partnership,' which is a term Viet Nam applies to particularly close bilateral relations. ${ }^{334}$ The content of these exchanges is not reported in detail, but they covered "defence-related

\footnotetext{
${ }^{333}$ New Zealand Ministry of Foreign Affairs and Trade, "New Zealand Defence Force Staff College Visits Viet Nam," no date, http://www.nzembassy.com/viet-nam/news/new-zealand-defence-force-staff-collegevisits-viet-nam.

${ }^{334}$ Thayer, "Vietnam's Security Outlook: Presentation to International Workshop of Asia-Pacific Security. National Institute of Defence Studies, Tokyo, Japan," 8.
} 
issues in Asia Pacific as well as opportunities for future cooperation in the region" including "the scope for strengthened bilateral defence links in future [...] and heightened contact and cooperation in regional forums.",336

\section{Educational exchanges}

Viet Nam was included in the MAP programme in June 2007, following the approval of the Minister of Defence. Much of the training and assistance provided to Viet Nam through MAP since then revolves around English language training, including the dispatch of NZDF teams to Viet Nam to provide English for Speakers of Other Languages training. Learning English enables them to participate in further training offered by New Zealand and other English-speaking nations, as well as to take part in military exercises where the participants use English as a common language. The Defence Learning Centre in Linton hosted nine Vietnamese officers for a ten week English language course in 2011. The NZDF has also sponsored Vietnamese personnel through Australian Defence Force language training. ${ }^{337}$ This military training complements the New Zealand Aid Programme's English Language Teaching for Officials Programme, which has seen several hundred mid-level and senior Vietnamese officials spend extended time in New Zealand since the early 1990s. ${ }^{338}$ Vietnamese military personnel have participated in a variety of education opportunities focusing on maritime skills, aeronautical engineering and senior officer development. ${ }^{339}$ Courses attended by Vietnamese personnel have ranged from English language training, initial and junior officer training, instructor training through to NZDF Command and Staff College. The official purpose of this training was to build capacity in the Vietnamese military through leadership development and professional training.

\footnotetext{
${ }^{335}$ New Zealand Government, “Talks with Viet Nam's Defence Minister,” Press Releases: Jonathan Coleman, March 22, 2013, http://www.beehive.govt.nz/release/talks-viet-nam\%E2\%80\%99s-defenceminister.

${ }^{336}$ New Zealand Embassy Ha Noi, "First Visit by a Vietnamese Defence Minister to New Zealand," News, accessed May 25, 2013, http://www.nzembassy.com/viet-nam/news/first-visit-by-a-vietnamese-defenceminister-to-new-zealand.

${ }^{337}$ New Zealand Defence Force, New Zealand Defence Force Annual Report 2011, 110.

${ }^{338}$ New Zealand Ministry of Foreign Affairs and Trade, "Relationship Between New Zealand and Viet Nam," no date, http://www.nzembassy.com/viet-nam/relationship-between-new-zealand-and-viet-nam/newzealand-and-viet-nam.

${ }^{339}$ New Zealand Defence Force, “Closer Defence Relations Between New Zealand and Vietnam,” September 16, 2009, http://asianz.org.nz/newsroom/regional-matters/nz-and-vietnam.
} 
Vietnamese officers generally attend the NZDF Command and Staff College every second year. A delegation from the VPA training and education headquarters visited the NZDF Staff College at the end of 2012 during annual MAP talks. Students and staff from the NZDF's Command and Staff College made a visit to Viet Nam in 2005. Since 2007, Viet Nam's National Defence Academy has accepted foreign officers in its training courses $^{340}$ and between 3 March and 4 June 2008 students and staff from the NZDF Joint Staff Course visited the Staff Course at the National Defence Academy during the course of their overseas study tour. ${ }^{341}$

\section{Port calls}

Ship visits between Viet Nam and New Zealand since the establishment of a formal defence relationship in 2001 are listed in Table 6. As has been the case with much of New Zealand's defence relations with Viet Nam, port calls to Viet Nam have been onesided. Viet Nam is reorienting from a land-focused force to a maritime one, but its major maritime interests are in the immediate littoral areas of the South China Sea. As a result, despite a great deal of maritime capability development, this has been focused on the development of corvettes, submarines and missile-armed attack boats suitable for operations in this area and Viet Nam has very little ability to send ships beyond the immediate region, let alone across the Pacific to New Zealand. Viet Nam's response has been to instead invite naval visits from other countries to them; invitations that New Zealand has been eager to accept. For some time naval diplomacy was limited by Viet Nam's policy of allowing one visit from one country, to one port once a year but this policy appears to be changing.

Table 6: Port calls conducted by Viet Nam and New Zealand $2001-\mathbf{2 0 1 3}^{342}$

\begin{tabular}{l|l} 
Date & Details \\
\hline 2002 & HMNZS Te Kaha and Endeavour visited Ho Chi Minh City. \\
2004 & HMNZS Te Kaha and Endeavour visited Ho Chi Minh City.
\end{tabular}

\footnotetext{
${ }^{340}$ Socialist Republic of Viet Nam Ministry of National Defence, Vietnam National Defence, 99.

${ }^{341}$ New Zealand Ministry of Foreign Affairs and Trade, "New Zealand Defence Force Staff College Visits Viet Nam."

${ }^{342}$ Compiled from New Zealand Ministry of Foreign Affairs and Trade, Viet Nam Ministry of National Defense, and New Zealand Defence Force sources.
} 


\begin{tabular}{l|l} 
Date & Details \\
\hline August 2006 & HMNZS Te Kaha and Endeavour visited Ho Chi Minh City. \\
June 2011 & HMNZS Te Mana visited Ho Chi Minh City. \\
24-29 April 2013 & HMNZS Te Mana visited Ho Chi Minh City
\end{tabular}

Some insight into the purposes of naval ship visits can be discerned from the June 2011 visit by HMNZS Te Mana. During its five-day visit, the crew paid courtesy visits to local government and local military commanders in the city. They played volleyball with a team from the Navy Technical School and undertook some sightseeing. ${ }^{343}$ While these visits served to promote friendly ties between the two nation's armed forces, they otherwise seemed to provide little in the way of substantive policy discussion or functional purpose. Indeed, while the RNZN planned to conduct the port visit at the Vietnamese naval base at Da Nang, its distance from New Zealand government representation and New Zealand business interests centred in Ha Noi and Ho Chi Minh City respectively meant that the ship was redirected to Ho Chi Minh City. The fact that Da Nang was regarded as lower down in priority demonstrated that diplomatic and trade interests took precedence over military engagement. As a senior MFAT official explained:

...if they had all the time in the world, we might have recommended it but if you are going to send a ship you have to touch other buttons and decide what the biggest bang for your buck is and it wasn't going down to Da Nang. ${ }^{344}$

Ship visits support wider government and commercial interests by raising New Zealand's profile in the country. There is usually a function for invited VIPs, as well as public open days, while the crew might engage in sporting contacts and undertake community work. During the most recent visit to Ho Chi Minh City, the ship's complement visited a girls home that was funded by the New Zealand Consular-General, and visited an international school described as New Zealand's largest education investment in Viet Nam. ${ }^{345}$

\footnotetext{
${ }^{343}$ Viet Nam News Agency, "New Zealand Naval Ship Visits Ho Chi Minh City," Footprint Travel, June 29, 2011, http://www.footprintsvietnam.com/Travelnews/2011/June/New-Zealand-naval-ship-visits-HoChi-Minh-City.htm.

${ }^{344}$ Author's interview with senior MFAT official, 15 February 2013.

${ }^{345}$ New Zealand Navy Ship Visits Ho Chi Minh City
} 


\section{Multilateral cooperation}

Viet Nam has demonstrated a keen ability take part in multilateral institutions. As ASEAN Chair in 2010, Viet Nam helped establish the ADMM+ and also used this role to internationalise its own bilateral security issues such as the South China Sea issue. Given ASEAN's traditional reluctance to become a security body, the establishment of $\mathrm{ADMM}+$ represented a significant milestone and was the first official defence forum involving Defence Ministers of ASEAN Member States and key extra-regional countries. ${ }^{346}$ Viet Nam's support for the ADMM+ was a response to its frustration over the 'talk shop' nature of the ASEAN Regional Forum. ${ }^{347}$ A senior MFAT official pointed out that Viet Nam "brokered [ADMM+] through in remarkable time, and really lead the process." 348

Viet Nam and New Zealand also work together in regional forums on a functional level. One example is the Western Pacific Naval Symposium (WPNS), which originated in the 1990s, when countries in the region acted beyond the framework of the Cold War to promote naval cooperation. Viet Nam first joined WPNS in 1994. Since being approved as a member, Viet Nam has only selectively participated, most likely as a result of economic woes. Viet Nam has not participated in any WPNS activities that have been hosted in New Zealand.

\section{Issues arising from New Zealand defence diplomacy with Viet Nam}

In terms of the challenges associated with the conduct of defence diplomacy discussed in Chapters Two and Three, the defence relationship between the NZDF and the VPA has proven to be unproblematic. Despite New Zealand's historical involvement in the Vietnam War there is not the same level of sensitivity and debate over the relationship, as has been the case in the United States. There have however, been limits to defence ties and the next section looks at two issues in more detail; the application of conditions on the relationship and reciprocity.

\footnotetext{
346 Viet Nam Ministry of Foreign Affairs, "First ADMM+ Chairman's Statement," October 13, 2010, http://www.mofa.gov.vn/en/nr040807104143/nr040807105001/ns101014100856/newsitem_print_preview. ${ }^{347}$ Thayer, "Vietnam's Security Outlook: Presentation to International Workshop of Asia-Pacific Security. National Institute of Defence Studies, Tokyo, Japan," 6.

${ }^{348}$ Author's interview with senior MFAT official, 15 February 2013.
} 


\section{Conditionality}

Unlike Australia and the United States, New Zealand has been able to pursue defence ties with Viet Nam without controversy. New Zealand was one of the first countries in the Western world to recognise the regime in the newly unified Republic of Viet Nam in 1975. The development of New Zealand's foreign relations with Viet Nam was unhindered by the impact of a large Vietnamese émigré population with antipathy to the Ha Noi government, as was the case in Australia and the United States. Viet Nam's withdrawal from Cambodia in 1989 resolved the biggest impediment to improving relations with the international community. It is also acknowledged that New Zealand was less likely to touch on awkward issues like freedom of religion and human rights. ${ }^{349}$ As a result of these factors, New Zealand's defence ties with Viet Nam have been unimpeded by domestic disapproval.

New Zealand has not imposed conditions on defence relations with Viet Nam. Despite doi moi and attendant political reforms, human rights abuses are still rife, ${ }^{350}$ and the VPA does have an internal security role. ${ }^{351}$ Yet such issues have not been brought up by New Zealand defence representatives in discussions with their Vietnamese partners. New Zealand's approach has been to address human rights concerns through separate channels. This was explained by an MFAT official as "we deal with human rights in a separate way. It wouldn't be discussed in a defence discussion." $" 352$

Nor does Viet Nam's system of government, being an authoritarian one-party state, or the highly politicised role of the VPA in domestic politics appear to present any impediments to New Zealand defence engagement. As the same MFAT official noted, "we accept Viet Nam is a communist system and we are not, and we have differences. We accept that we do things differently and there's never any need to discuss it." ${ }^{353}$ While discussing aspects of the early diplomatic relationship, the official did admit that "there was a bit of a distance created by concerns over different political systems [...] so it didn't progress

\footnotetext{
${ }^{349}$ Daljit Singh, ASEAN's Perspective of New Zealand's Place in Asia, Outlook 2011 Series (Wellington N.Z.: Asia: New Zealand Foundation, 2011), 9.

${ }^{350}$ United States Department of State, "Vietnam," Country Reports on Human Rights Practices for 2011, 2011, http://www.state.gov/j/drl/rls/hrrpt/humanrightsreport/index.htm?dynamic_load_id=18631.

${ }^{351}$ Thayer, "Vietnam's Security Outlook: Presentation to International Workshop of Asia-Pacific Security. National Institute of Defence Studies, Tokyo, Japan," 2.

${ }^{352}$ Author's interview with senior MFAT official, 15 February 2013.

${ }^{353}$ Ibid.
} 
rapidly." 354 This notwithstanding, New Zealand increasingly shares a number of common security interests with Viet Nam. Both countries have a strong commitment to nuclear disarmament and non-proliferation. ${ }^{355}$ Viet Nam attended a Proliferation Security Initiative meeting in New Zealand in $2007 .{ }^{356}$

\section{Reciprocity}

Viet Nam set self-imposed limits on its defence relationships. The 2004 White Paper stated that it "[...] consistently advocates neither joining any military alliance not giving any foreign countries permission to have military bases in Viet Nam." 357 For some time Viet Nam imposed limits on its own ability to exercise with foreign militaries and restricted foreign visits to one visit from each country per year, although defence policymakers did not acknowledge these as a restraint on New Zealand's defence relationship. ${ }^{358}$ The list of strategic-level visits in Table 5 illustrates a marked imbalance in the number of reciprocal exchanges between New Zealand and Viet Nam. This was part of a broader trend: from all countries, Viet Nam received 40 delegations by Service Chiefs and above between 1990 and 2004. In the same period, Viet Nam only sent nine equivalent delegations abroad ${ }^{359}$ and none came to New Zealand. A large factor, and one recognised by the NZDF, is the lack of resources the VPA is able to contribute to its relationship. Viet Nam's Ministry of National Defence admitted that participation in defence diplomacy was constrained by the limitations of Viet Nam's own internal resources. $^{360}$ Despite enjoying military spending at 2.5 percent of Viet Nam's gross domestic product, ${ }^{361}$ the VPA has a range of more pressing priorities, such as building its maritime presence in the South China Sea to counter competing resource claims from its neighbours.

\footnotetext{
354 Ibid.

${ }^{355}$ Socialist Republic of Viet Nam Ministry of National Defence, Vietnam's National Defense in the Early Years of the 21st Century, 15.

356 Thayer, "The Outlook for US-Vietnam Relations: Presentation to East-West Center, Washington D.C."

${ }^{357}$ Socialist Republic of Viet Nam Ministry of National Defence, Vietnam's National Defense in the Early Years of the 21st Century, 14.

${ }^{358}$ Author's interview with Paul Sinclair, 28 November 2012.

359 Thayer, "Vietnam's Defence Diplomacy and Its Impact on Foreign Relations."

360 Joann Saw, "Defence Diplomacy in South East Asia: Conference Report," 9.

${ }^{361}$ United States Central Intelligence Agency, "Military: Vietnam," The World Factbook, January 7, 2013, https://www.cia.gov/library/publications/the-world-factbook/index.html.
} 


\section{Conclusion}

Vietnam's defence relationship with New Zealand was likely initiated by Ha Noi. Like the People's Liberation Army of China, it was economic reform and political openness which paved the way for the Viet Nam People's Army to develop external defence relations with a range of countries, including New Zealand, that were outside its traditional communist orbit. The strategic situation that Viet Nam found itself in, once its only ally the Soviet Union collapsed in 1991, compelled Viet Nam to embark on its own process of 'new' defence diplomacy. It had to develop relations with former foes and take part in new multilateral institutions to meet basic national security needs. Having renewed the relationship with former Cold War sponsor Russia and rejuvenated old ties with former foes France and the United States, Viet Nam invited the influence of major powers back into its immediate region. Once this was achieved, Viet Nam sought assistance with modernising its military and improving its defence-industrial base. This enabled Viet Nam to address territorial disputes and resource claims with increased confidence and international support.

It was at this point that Viet Nam began to engage with New Zealand. The VPA's desire to modernise meant that initial ties began with training and support assistance at a low level. This was eventually formalised through Viet Nam's admission to the NZDF's MAP programme in 2007. In the meantime, Viet Nam's regional profile has grown and Viet Nam is now an influential leader in the security space, as their role in the establishment of ADMM+ demonstrates. Viet Nam's enthusiasm to progress the New Zealand defence ties at the strategic level led to the initiation of regular high-level contacts in which regional security concerns could be shared and annual bilateral talks now take place between the two Defence establishments. New Zealand officials explained that New Zealand has an interest in developing a close relationship with Viet Nam in order to share thinking about a range of regional security issues such as North Korea and the South China Sea disputes. Defence dialogue with Viet Nam provides New Zealand a further opportunity to act as a responsible regional partner and obtain access to Viet Nam's views on the regional security environment. New Zealand is looking for new ways to engage militarily with Viet Nam and following the VPA's announcement that they are moving into the peacekeeping space, New Zealand has expressed its willingness to assist sharing experience and training to encourage them in this initiative. 
Ship visits remain an important and highly visible part of the defence relationship. The example provided by the frigate visit to Ho Chi Minh City in 2011 exposed the way in which defence ties are used by New Zealand primarily to further diplomatic and trade interests. It suggests that the military value of engagement is lower priority but this might be a peculiarity of ship visits. Other military training and assistance is more targeted to Viet Nam's needs, revolving mainly around English language skills to enable VPA personnel to access further training from New Zealand and other nations.

One theme that permeates the development of defence relations between New Zealand and Viet Nam is the lack of resources, particularly on the Vietnamese side, to participate. Viet Nam's own priorities are necessarily focused on its immediate neighbours, China and ASEAN members, and there has not been much scope for the maturing of the defence relationship with New Zealand. In these circumstances, New Zealand has recognised their limitations and sought engagement where it can, most notably in multilateral forums where Viet Nam is able to engage with New Zealand together with Viet Nam's more important defence partners - China, the United States, Japan and other Asian powers. That said, New Zealand officials describe defence links as more or less equal.

Viet Nam's own slow progress in developing defence ties with New Zealand and other nations demonstrates the way in which it takes time to develop the nuances and understanding required to build their confidence in the role and recognise the possibilities that defence diplomacy offers. New Zealand has been a willing partner in this process. 


\section{CHAPTER SIX New Zealand's defence relations with Indonesia}

\section{Introduction}

Indonesia is the largest country in South East Asia. It is enjoying increasing stability and prosperity and its influence is growing as it asserts itself more as a regional and international leader. ${ }^{362}$ As such it is becoming an attractive regional partner for New Zealand politically and economically. But the New Zealand government has faced a difficult dilemma in balancing military cooperation with Jakarta with its support for democracy, good governance and the upholding of human rights. Over time the military relationship has been shaped by changing strategic priorities and domestic opinion.

New Zealand's changeable defence relationship with Indonesia illustrates one of the key tensions between 'old' defence cooperation and 'new' defence diplomacy. NZDF links with Indonesia's armed forces, the Tentara Nasional Indonesia (TNI) demonstrate the double standard that Cottey and Forster identified as implicit in defence diplomacy by Western countries; that is support for greater civilian control over the military in some cases, and close military cooperation with authoritarian regimes in others. ${ }^{363}$ This chapter discusses defence relations with Indonesia in two separate phases: before 1999 and after 2000.

\section{Indonesia as a former and potential foe}

Despite a largely "positive, if shallow" 364 history of political relations between the two countries, Indonesia has fulfilled the roles of both a former enemy and a potential enemy for some time. While New Zealand was one of the first countries to recognise newly independent Indonesia, security concerns arose during the late 1950s when President Sukarno set out to establish regional dominance. ${ }^{365}$ Following the success of a similar strategy in Dutch West Papua, Indonesia initiated a campaign to destabilise the new Federation of Malaysia.

\footnotetext{
${ }^{362}$ Centre for Strategic Studies New Zealand, Projecting Our Voice: Major Power Relationships in Asia, the Responses of Regional Organisations and the Implications for New Zealand., 19.

${ }_{363}$ Cottey and Forster, Reshaping Defence Diplomacy, 32.

${ }^{364}$ Michael Green, "Uneasy Partners: New Zealand and Indonesia," in Southeast Asia and New Zealand: A History of Regional and Bilateral Relations, ed. Anthony L. Smith (Singapore: Institute of Southeast Asian Studies, 2005), 176.

${ }^{365}$ Robert Miles, "Indonesia Under the Spotlight," New Zealand International Review 17, no. 4 (August 1992): 24.
} 
Initially, New Zealand did not want to get involved in the dispute, favouring its good relationship with Indonesia and being wary of being drawn into another drawn-out insurgency like the Malayan Emergency. ${ }^{366}$ However, once Indonesian troops began crossing into Borneo, New Zealand armed forces joined those of Britain and Australia in countering their infiltration. While the RNZAF stood ready to bomb Jakarta, ${ }^{367} \mathrm{New}$ Zealand and Indonesian troops engaged in skirmishes. ${ }^{368}$ The original purpose of the Five Power Defence Arrangements established in 1971 and discussed in Chapter Three was to provide a measure of assurance to Singapore and Malaysia in the event of further Indonesian aggression.

A decade later, Indonesia's annexation of East Timor in 1975 provided another example of Indonesian territorial expansionism, and the consolidation of Indonesian rule was to prove brutal and bloody for the Timorese. By this time, President Suharto had proven anti-communist credentials and his Timor operation was unopposed by regional powers exhausted by the conflict in Indochina, New Zealand among them. By the 1980s officials in Australia and New Zealand no longer believed Indonesia was a direct security threat, ${ }^{369}$ but a disconnect remained between government views and public opinion. ${ }^{370}$ During the 1990s, public opinion surveys found one in five Australians considered Indonesia a potential threat. ${ }^{371}$ Indonesia was also considered to pose a renewed threat to the integrity of Malaysia and potentially Papua New Guinea. ${ }^{372}$

Even though Indonesia became a democratic multi-party state following elections in 1999 and introduced military reforms, Australian public opinion surveys conducted since this time continued to demonstrate Indonesia is the most frequently mentioned potential threat

\footnotetext{
${ }^{366}$ Chris Pugsley, "Your Target - Jakarta," New Zealand Defence Quarterly no. 14 (Spring 1996): 12.

${ }^{367}$ Ibid.

368 Ibid., 14.

${ }^{369}$ Paul Dibb, The Review of Australia's Defence Capabilities (Canberra: Australian Government Publishing Service, 1986), 1. 1

${ }^{370}$ Frank Wilson, Indonesia and Its Significance for New Zealand, Outlook 2012 Series (Wellington N.Z.: Asia New Zealand Foundation, May 2012), 27.

${ }^{371}$ Ian McAllister, Public Opinion in Australia Towards Defence, Security and Terrorism, Special Report 16 (Australian Strategic Policy Institute, 2008), 12, http://www.aspi.org.au/publications/publications_details.aspx?ContentID=180.

${ }^{372}$ Miles, "Indonesia Under the Spotlight," 26.
} 
to national security. ${ }^{373}$ The Indonesian President himself acknowledged these opinions continued to exist when he said:

Even in the age of cable television and internet, there are Australians who still see Indonesia as an authoritarian country, as a military dictatorship, as a hotbed of Islamic extremism or even as an expansionist power. ${ }^{374}$

Frank Wilson analysed the New Zealand Defence White Paper 2010 and pointed out that:

a number of the possible security threats identified in the White Paper could relate to Indonesia. For example the necessity to maintain open sea routes, the dangers of illegal incursions by asylum seekers and illegal fishing and possible terrorist attacks could in theory involve Indonesia. And the use of force is contemplated in two scenarios that could be linked to Indonesia. These are "as part of New Zealand's contribution to the Five Power Defence Arrangements" and in circumstances when New Zealand would "immediately respond to an attack on Australia."375

\section{Indonesia's Approach to Defence Diplomacy}

Since its inception, Indonesia has followed a non-aligned foreign policy. It has avoided becoming involved in alliances with other countries and has avoided collective security arrangements. As a founding member of ASEAN, Indonesia was central in articulating ASEAN's policy of non-interference in domestic affairs, which engendered the longstanding reluctance among its members to form a formal ASEAN security arrangement. Indonesia has always sought an "independent and active" foreign policy. ${ }^{376}$ A recent manifestation of this independent and active foreign policy has been the centrepiece of Indonesia's foreign policy - dynamic equilibrium in the Asia Pacific. This is achieved through the strengthening of regional cooperation and institutions to ensure no single power can dominate. ${ }^{377}$

\footnotetext{
${ }^{373}$ Ian McAllister, Representative Views: Mass and Elite Opinion on Australian Security (Australian Strategic Policy Institute, 2005), 13.

http://www.aspi.org.au/publications/publication_details.aspx?ContentID=75\&pubtype=5; McAllister, Public Opinion in Australia Towards Defence, Security and Terrorism.

${ }^{374}$ Commonwealth of Australian, Senate Official Hansard No.3. 10 March 2010 retrieved from http://www.scribd.com/doc/94377156/Address-Indonesian-President-to-Australian-Parliament-10-Mar-10Hansard

${ }^{375}$ Frank Wilson, Indonesia and Its Significance for New Zealand, 10.

376 Ibid., 8.

${ }^{377}$ Gregory Poling, "Dynamic Equalibrium: Indonesia's Blueprint for a 21st-Century Asia Pacific," Southeast Asia from the Corner of 18th \& K Streets IV, no. 5 (March 7, 2013): 1.
} 
The changing character of Indonesia's defence relations reflects the central role of the military in Indonesian politics, economy and society, which is itself a product of Indonesia's unique geography and development as an independent state. The TNI has a strong nationalist fervour and it carved out a special role for itself as the defender of the nation. The TNI was traditionally an "all-inclusive, intrusive, and the dominant force in the country's social and political life." 378 It also meant that the TNI did not believe they were subordinate to civil authority. ${ }^{379}$

According to their former doctrine of dwi fungsi (dual function), the TNI acted as a guardian of the state through participation in political processes. This meant that the military played a dual function in both the military and civilian spheres. From 1998, $d w i$ fungsi was replaced with a new doctrine, paradigma baru (New Paradigm) that clearly shunned political involvement and promoted power sharing with the civilian government. It placed more emphasis on the military's national security role while making clear the police's role in internal security. However, due to a range of factors, the TNI continued to wield considerable influence and remains largely autonomous despite its withdrawal from a prominent public role.

For much of its history, the TNI's focus was on its immediate neighbours and territorial sovereignty, unresolved territorial disputes, the need to protect its EEZ and the security of resources. $^{380}$ More recently, Indonesia's defence policy emphasised the use of diplomacy, through regional and international cooperation, as the first line of defence. ${ }^{381}$ Indonesian defence diplomacy was oriented towards building a better working relationship with partners and rivals in order to prevent conflicts arising or, in the recent words of the Indonesian President, “a 'million friends and zero enemies' diplomatic

\footnotetext{
${ }^{378}$ Smith and Tom Peterman, "Report from the Conference on Evolving Roles of the Military in the AsiaPacific" (Honolulu, Hawaii: Asia Pacific Centre, 2000), http://www.apcss.org/Publications/Report_Evolving_Roles.html.

${ }^{379}$ Michael Green, Indonesia's Armed Forces in the Democratic Era, Strategic Briefing Papers (Centre for Strategic Studies, Victoria University of Wellington, November 2011), 1. http://www.victoria.ac.nz/css/Strategic_Briefing_Papers/Vol.6\%202011/Indonesia\%27s\%20Armed\%20For ces\%20SBP\%20Vol6\%20P1\%20Nov2011.pdf.

${ }^{380}$ Rizal Sukma, "Indonesia's Security Outlook, Defence Policy and Regional Cooperation," in Asia Pacific Countries' Security Outlook and Its Implications for the Defence Sector, NIDS Joint Research Series 5 (Tokyo: The National Institute for Defense Studies, 2010), 21, http://www.nids.go.jp/english/publication/joint_research/series5/pdf/5-1.pdf.

${ }^{381}$ Ibid., 10.
} 
strategy." 382 Military ties and exercises assisted Indonesia and fellow ASEAN nations to get to know and understand each other, thus removing suspicions and misunderstanding. ${ }^{383}$ As the Indonesian Foreign Minister Marty Natalegawa explained, the development of bilateral defence relationships with a range of countries including China are regarded as "part and parcel of the developments and dynamics of the region."384

Indonesia has acknowledged that the TNI has come a long way in becoming more professional and now considers engagement with other countries like the United States, and by implication New Zealand, as a necessity to ensure that the process of democratisation becomes irreversible. ${ }^{385}$ Indonesian officials also hinted at the role combined exercises such as search and rescue cooperation play in raising the comfort level between countries involved in territorial disputes in the region. ${ }^{386}$

\section{The Development of Indonesia - New Zealand Defence Diplomacy}

Former Ambassador to Indonesia, Michael Green, described New Zealand's defence links with the country as 'spasmodic'. ${ }^{387}$ This ties are discussed in two phases: the first covering defence links prior to 1999, and the second looking at the renewal of defence cooperation since 2000 .

The first phase of defence contacts began in 1953, with the port call by HMNZS Black Prince, but it was not until 1961 that the next significant event occurred, when TNI General Nasution visited New Zealand. Nasution was a key figure in the Indonesian Army, and played a part in articulating the dwi fungsi philosophy. The purpose of his visit was to state Indonesia's position on the annexation of Dutch West Guinea (modern

\footnotetext{
${ }^{382}$ H Susilo Bambang Yudhoyono, "IISS Keynote Address," accessed August 9, 2012, http://www.iiss.org/conferences/the-shangri-la-dialogue/shangri-la-dialogue-2012/speeches/openingremarks-and-keynote-address/keynote-address/.

${ }^{383}$ Ibid.

${ }^{384}$ Australia Network, "Interview with Marty Natalegawa, Indonesia’s Foreign Minister," accessed January 28, 2013, http://australianetwork.com/focus/s3440427.htm.

${ }^{385}$ Council on Foreign Relations, "A Conversation with Marty Natalegawa, Minister of Foreign Affairs, Republic of Indonesia," September 20, 2010, http://www.cfr.org/indonesia/conversation-marty-natalegawaminister-foreign-affairs-republic-indonesia/p22984.

${ }^{386}$ Ibid.

${ }^{387}$ Green, "Uneasy Partners: New Zealand and Indonesia," 176.
} 
West Papua), and to reassure regional governments that it did not have similar ambitions for East New Guinea (modern Papua New Guinea), North Borneo or East Timor. ${ }^{388}$

It was not until after the failed 1965 coup and military crackdown, which deposed an increasingly unstable Sukarno and ended the Indonesian policy of Konfrontasi with the newly established Federation of Malaysia, that more substantial military-to-military contacts could be contemplated by New Zealand. The fact that Indonesia now had a military-backed government gave defence links new relevance and it was New Zealand's Minister of Defence who was the first Cabinet Minister to visit Jakarta and meet the new leaders. ${ }^{389}$ In 1974 New Zealand formalised defence links with Indonesia with the appointment of a Defence Attaché to Jakarta. ${ }^{390}$ The attaché assisted with the development of a framework for defence cooperation which included assistance in areas such as dentistry, resource management and naval dockyard refitting, as well as VIP visits and inspections to ascertain further training and exercising opportunities. At the outset, defence links were recognised for their "part of the total effort" to "increase cooperation with Indonesia in all fields.",391

Stopovers in Indonesia while in transit to FPDA exercises provided New Zealand warships and aircraft the opportunity to exercise on a limited basis with the TNI. A more formal programme of joint naval and air exercises followed which were considered significant as Indonesia seldom exercised with foreign counterparts in line with its nonaligned and self-reliant stance. ${ }^{392}$ Green considered that the small size and lack of hostile intent posed by New Zealand military forces facilitated the gradual expansion by Indonesia of defence cooperation from the mid-1970s through to the mid-1990s. The high regard in which Indonesia held its relationship with New Zealand could be gauged by the 1979 visit of Indonesian ships to New Zealand, only the second time they had ventured out of Indonesian territorial waters. ${ }^{393}$ It was also noted in 1981 that the New Zealand defence attaché was the only one allowed to walk freely around Indonesian

\footnotetext{
388 “Nasution Speaks of 'Frank' N.G. Talks,” Sydney Morning Herald, April 24, 1961, http://news.google.com/newspapers?id=DS9WAAAAIBAJ\&sjid=_OUDAAAAIBAJ\&pg=7236\%2C61297 06.

${ }^{389}$ Green, "Uneasy Partners: New Zealand and Indonesia," 171.

${ }^{390}$ Ibid., 176.

${ }^{391}$ New Zealand Defence Attaché, Defence Cooperation with Indonesia.

392 Green, "Uneasy Partners: New Zealand and Indonesia," 177.

393 “Brief for Prime Minister's Visit to Indonesia 25-30 May 1980," May 13, 1980, Jakarta File 30/4/1.
} 
military facilities without an escort. ${ }^{394}$ Former Ambassador Michael Green attributed this to the small size of New Zealand forces and New Zealand's lack of any hostile motives. ${ }^{395}$ Despite these positive developments, the defence relationship was not particularly active. The New Zealand defence attaché observed at the time that the programme sending Indonesia officers to New Zealand "started off with a hiss and a roar, but $[\ldots]$ was temporarily suspended due to financial limitations." Low-level naval exercises continued to take place every two years, while air force exercises occurred more occasionally, into the 1990s. ${ }^{396}$ The last Army exercise between Indonesia and New Zealand occurred in 1980.

Other than joint military exercises (discussed below), much of New Zealand's military cooperation with Indonesia has been conducted through the Mutual Assistance Programme. MAP links with Indonesia began in 1973 and by 1994, Indonesia was receiving the second greatest share of New Zealand military assistance after Malaysia. ${ }^{397}$ Once Indonesia began acquiring the Skyhawk aircraft, which was also in the New Zealand inventory, training and exercises broadened. ${ }^{398}$ For more than five years the New Zealand air force was the only foreign air force to conduct operational exercises with that of Indonesia. ${ }^{399}$

Differences in language, capabilities, military culture and strategic outlook limited the defence relationship however. For example, an invitation to send a New Zealand student to Indonesia's Staff and Command College in the mid-1980s had to be declined due to the lack of a qualified officer able to speak Indonesian. ${ }^{400}$ It was also reported that the Indonesians continued to be suspicious about New Zealand. A request to use Indonesian territory by Singapore-based RNZAF aircraft was declined due to suspicion on the part of Indonesia about New Zealand motives. ${ }^{401}$ During the 1990s, fewer and fewer TNI personnel passed through MAP training.

\footnotetext{
${ }^{394}$ Colonel Pearce, MAP Visit to South East Asia 26 September to 11 October 1981, November 10, 1981, Jakarta File 30/4/1.

395 Green, "Uneasy Partners: New Zealand and Indonesia," 177.

${ }^{396}$ Ibid., 188.

${ }^{397}$ Joe Buchanan, New Zealand Military Cooperation with Indonesia (Wellington, N.Z.: Peace Movement Aotearoa, 1995), 1.

${ }^{398}$ Ibid., 2.

${ }^{399}$ Green, "Uneasy Partners: New Zealand and Indonesia," 176.

400 "Letter to New Zealand Defence Attache," July 14, 1983, Jakarta File 30/4/1.

401 "Cable from NZDEFJAK to NEWFORSEA," May 10, 1984, Jakarta File 30/4/1.
} 
Relations were hampered by the TNI's human rights abuses in Timor, and in particular by units such as Kopassus (discussed further in the next section). Human rights and peace movements within New Zealand increasingly condemned TNI activities and New Zealand's complicity by training and supporting them. Opponents criticised the arguments put forward by officials defending defence ties, pointing out that the contention that military links provided opportunities to make New Zealand's views known on Timor was "hypocrisy" by "training a military to kill more efficiently and at the same time criticising them for doing just that." ${ }^{, 402}$ Opponents argued that 20 years of cooperation had not changed the TNI's focus on internal security or encouraged professionalism or respect for democracy and the rule of law:

In seeking training with New Zealand, the Indonesian armed forces know what they want and the NZDF claims to provide just that: increased effectiveness of their armed forces. Training in combat in the military environment (which is inherently and openly undemocratic) is hardly the best way to export democratic values. ${ }^{403}$

A member of an Indonesian opposition group commented on New Zealand defence ties, saying "I think its hypocrisy to maintain that relationship when you know what they are doing in Indonesia - killing people and abusing human rights... that just makes them stronger and encourages them to behave in an undemocratic way."404

In September 1999, defence links were cut altogether following the role played by the TNI in post-independence ballot violence in Timor. In his announcement, Defence Minister Max Bradford “expressed his regret that New Zealand's long-standing relationship with an important regional partner was coming under strain. But the fundamental issue - whether a decision openly and democratically arrived at, should be allowed to be overturned by intimidation - was too important to ignore."405 Maire Leadbeater, a key figure in New Zealand's Indonesian human rights movement, wrote "it had taken 26 years for the government to decide that the Indonesian military was not so

\footnotetext{
${ }^{402}$ Buchanan, New Zealand Military Cooperation with Indonesia, 6.

${ }^{403}$ Ibid.

${ }^{404}$ Maire Leadbeater, "New Zealand Trains Indonesia’s Military,” Peace Researcher no. 16 (August 1998): $13-14$.

${ }^{405}$ Max Bradford, "New Zealand Suspends Military Co-Operation with Indonesia," Releases, September 10, 1999, http://www.beehive.govt.nz/release/new-zealand-suspends-military-co-operation-indonesia.
} 
benign after all." ${ }^{406}$ Interestingly though, the Defence Attaché in Jakarta remained in his post, and was replaced in 2000. The new officer, not having had the benefit of attending Indonesian Staff College, lacked the contacts and penetration into the TNI hierarchy his predecessor enjoyed. ${ }^{407}$ Wider defence links were not restored until 2007. The relationship since then is explored in the next section of this Chapter.

\section{The renewal of the Indonesia - New Zealand defence relationship}

With the sixth largest economy in the world, a generally moderate and nominally secular approach to Islam and a successful transition to democracy, Indonesia emerged as an important and promising partner for New Zealand. It has emerged as one of the top ten export destinations for trade. ${ }^{408}$

Defence cooperation between Indonesia and New Zealand is still regarded as part of a broad-based, thorough and close political relationship. ${ }^{409}$ The renewal of defence ties was announced by Foreign Minister Winston Peters in a speech in December 2006. In it, he announced that Indonesia had accepted an invitation to have an officer attend Command and Staff College in 2007, and that the College's international tour would incorporate Indonesia. ${ }^{410}$ Speaking shortly after the TNI officer arrived in New Zealand, Minister of Defence Phil Goff stated "Indonesia has made impressive steps to strengthen democracy, [...] Sufficient good things have happened so [we need] to acknowledge they have made steps towards reform." 411 Foreign Minister Winston Peters detailed these steps, pointing out "removal of the armed forces from an active role in politics, the establishment of civilian control over the military, the removal of the armed forces from commercial activity, and the strengthening of military professionalism..."412

The resumption of military ties may have been assisted by NZDF involvement in tsunami relief in the Aceh province in early 2005. The Foreign Minister at the time, Phil Goff,

\footnotetext{
${ }^{406}$ Maire Leadbeater, Negligent Neighbour: New Zealand's Complicity in the Invasion and Occupation of Timor-Leste (Nelson, N.Z.: Craig Potton Publishing, 2006), 207.

407 Author's interview with Chris Elder, 27 March 2013.

${ }^{408}$ New Zealand Ministry of Foreign Affairs and Trade, Our Future with Asia, 32.

${ }^{409}$ Centre for Strategic Studies New Zealand, Projecting Our Voice: Major Power Relationships in Asia, the Responses of Regional Organisations and the Implications for New Zealand., 22.

${ }^{410}$ Winston Peters, "Security Policy Responses to a Challenging World," Speeches, December 13, 2006, http://www.beehive.govt.nz/speech/security-policy-responses-challenging-world.

${ }^{411}$ Joseph Barratt, "Ties with Indonesia Quietly Renewed," Te Waha Nui Online, June 1, 2007, http://www.tewahanui.info/news/070601_Indonesia.shtml.

${ }^{412}$ Ibid.
} 
accompanied the defence force team, ${ }^{413}$ and it was under his term as Defence Minister, which he took over in October that year, that ties were eventually restored. It is important to note that despite the 2002 Bali bombing in which Islamic militants killed three New Zealanders, the New Zealand government did not revert to old patterns of defence cooperation; New Zealand did not restore defence links to make Indonesia an ally of convenience under the auspices of countering terrorism. Instead, it allowed new forms of security engagement to begin, notably through a police liaison. ${ }^{414}$ Since 2006 , defence ties have remained low-key and cautious; limited to education, non-combat training, cooperation in humanitarian operations and navy-to-navy engagement. ${ }^{415}$ This was a function of both domestic opposition and material limitations on the NZDF's ability to further develop the relationship. ${ }^{416}$

Following Indonesia's transition to democracy in 1999, the controversy over defence links might have been expected to decline, however this has not been the case. In a submission to the New Zealand Defence Review 2009, the Indonesia Human Rights Committee stated:

Although New Zealand's defence ties are not large scale they do serve to confer a 'seal of respectability' on the Indonesian military just as such ties did during the Suharto era... 417

While reforms saw the military's role in political life curtailed and responsibility for internal security functions passed to the police, defence cooperation remained a sensitive subject within New Zealand due to Indonesia's failure to hold military personnel accountable for past crimes, as well as an inability to stop ongoing human rights abuses that continue to occur in Indonesia's other restive provinces such as West Papua and Aceh. $^{418}$

\footnotetext{
${ }^{413}$ Author's interview with Chris Elder, 27 March 2013.

${ }^{414}$ Green, "Uneasy Partners: New Zealand and Indonesia," 192.

${ }^{415}$ Frank Wilson, Indonesia and Its Significance for New Zealand, 24.

${ }^{416}$ Green, Indonesia's Armed Forces in the Democratic Era, 1.

${ }^{417}$ Indonesia Human Rights Committee, "Submission to Defence Review 2009," August 23, 2009, http://www.defence.govt.nz/pdfs/defence-review-2009-public-submissions-oia/171\%20\%20Defence\%20Review\%2009\%20public\%20submission.PDF.

${ }^{418}$ Ibid.
} 
Maire Leadbeater wrote in 2010 that "The military has never faced up to its role in supporting Suharto's tyranny and its officers remain unaccountable for their crimes against humanity. Credible charges of horrendous East Timor crimes have proved no barrier to advancement..."419 The key issue was the TNI's culpability for gross human rights abuses in East Timor. Opponents of New Zealand's links to Indonesia point out that "since the fall of the Suharto regime in 1998, no high ranking Indonesian military officer has been prosecuted for a human rights crime..." and they insist that military cooperation should be conditional on these leaders being brought to trial. ${ }^{420}$

In terms of New Zealand defence policy, Robert Ayson noted that the 2010 Defence White Paper had a "worrying absence" of any mention at all of Indonesia. ${ }^{421}$ This lack of official acknowledgement of military ties to Indonesia was puzzling considering that Indonesia is New Zealand's nearest Asian neighbour. ${ }^{422}$ However it perhaps made sense considering the high degree of public disapproval of the TNI and its complicity in human rights abuses. The low level of contemporary NZDF cooperation serves to keep the relationship out of the public eye. However, there is a high level of public scrutiny within New Zealand. Defence relations with Indonesia were in the public eye as recently as 2012 with condemnation about a Kopassus ${ }^{423}$ officer being trained at Staff and Command College. Catherine Delahunty, a Green Party Member of Parliament, stated "the Defence Force's role in training someone from a military unit well known for human rights abuses compromises the reputation of New Zealand." 424 The issue of human rights abuses, particularly the failure to hold anyone accountable for them, will continue to hamper New Zealand's defence diplomacy with Indonesia.

\footnotetext{
${ }^{419}$ Maire Leadbeater, "NZ Aid Fosters Impunity, Status Quo by Indonesian Security Forces," New Zealand International Review 35, no. 5 (October 2010): 11.

${ }^{420}$ Indonesia Human Rights Committee, "Submission to Defence Review 2009."

${ }^{421}$ Ayson, "Force and Statecraft: Strategic Objectives and Relationships in New Zealand's 2010 Defence White Paper," 27.

${ }^{422}$ The Ministry of Foreign Affairs website, which trumpets New Zealand's defence links with both China and Viet Nam, does not mention our defence cooperation at all when providing information on New Zealand's relationship with Indonesia (see Viet Nam Ministry of Foreign Affairs, "First ADMM+ Chairman's Statement.")

${ }^{423}$ An Indonesian special forces unit linked to human rights abuses in East Timor and West Papua.

${ }^{424}$ New Zealand Green Party, "New Zealand Defence Force Connection To Military Violence In West Papua," Press Releases: Catherine Delahunty, June 18, 2012, http://www.greens.org.nz/press-releases/newzealand-defence-force-connection-military-violence-west-papua.
} 


\section{High-level exchanges since 2007}

High-level military exchanges between Indonesia and New Zealand since 2007 are listed in Table 7. It is notable that no New Zealand Defence Minister has visited Jakarta since the renewal of defence relations. Phil Goff did visit Jakarta, but characterised his visit as part of his Trade portfolio. He did however meet Indonesian Defence Minister Juworno Sudarsono during this visit.

Table 7: High-level Defence Exchanges between Indonesia and New Zealand since 2007

\begin{tabular}{l|l} 
Date & Delegation \\
\hline August 2007 & $\begin{array}{l}\text { Phil Goff, Minster of Defence (as Trade Minister). } \\
\text { Rear Admiral Tony Parr, Chief of Navy to Indonesia. } \\
\text { April } 2011\end{array}$ \\
Early 2012 & $\begin{array}{l}\text { John McKinnon, Secretary of Defence to Indonesia. } \\
\text { Indonesia. }\end{array}$ \\
$16-18$ September 2012 & $\begin{array}{l}\text { Rear Admiral Tony Parr, Chief of Navy to Indonesia. } \\
\end{array}$
\end{tabular}

\section{Educational and Functional exchanges since 2007}

The NZDF regarded officer exchanges, continued attendance at the NZDF Staff College and greater English language training as essential areas for the TNI's development. These activities were focused at junior to mid-level officers who will be the TNI's next generation of leaders, and the intent was to both professionalise them and provide them with skills to enable them to conduct operations with other multinational partners. Numbers each year are small, and are nowhere near the 25-30 Indonesian personnel each year that were being trained in the 1990s. In return, Indonesia held a place open for a NZDF student at the Institute of National Resilience (Lemhannas) in Jakarta. Students from the institute have visited New Zealand, most recently for three days in early September 2012. There have been a number of functional exchanges, consisting mainly of meetings to coordinate cooperation, such as the visit by Paul Sinclair, the Head of the International Defence Relations Branch to Jakarta for defence talks in October 2010.

\section{Port calls since 2007}

Naval cooperation between the RNZN and the Indonesian Navy, the TNI-Angkatan Laut, did not resume until 2009 and have remained low key, but it was regarded as an important 
development in the renewed relationship. On the occasion of the first contact, which occurred during the Indonesian fleet review, the NZDF was at pains to explain this as a multinational event rather than a bilateral one. ${ }^{425}$ Ship visits between Indonesia and New Zealand since the resumption of defence ties are listed below in Table 8.

Table 8: Port calls conducted by Indonesia and New Zealand since 2007

\begin{tabular}{l|l} 
Date & Details \\
\hline 12-20 August 2009 & $\begin{array}{l}\text { HMNZS Canterbury visited Manado and Bitung, Sulawesi } \\
\text { (Indonesian Navy International Fleet Review) } \\
\text { November 2009 }\end{array}$ \\
HMNZS Endeavour visited Jakarta. \\
HMNZS Te Mana visited Jakarta. \\
HMNZS Te Kaha visited Surabaya.
\end{tabular}

\section{Multilateral cooperation since 2007}

Indonesia also conducts many defence diplomacy activities through multilateral forums, that New Zealand attends, including the range of ASEAN bodies such as the ASEAN Regional Forum, the ASEAN Defence Ministers Meeting Plus and Defence Senior Officials Meeting-Plus (which Indonesia agreed to convene ${ }^{426}$ ), as well as the Shangri-La Dialogue. New Zealand chaired the ADMM+ Expert Working Group on Peacekeeping Operations with the Philippines. As part of the process it co-hosted a meeting held in Indonesia in 2013. In 2011, Indonesia established its own Jakarta International Defence Dialogue (JIDD). This annual event brought military and defence ministry officials together with academics from the Indonesian Defence University. Indonesia's intent was to establish JIDD as the region's principal security coordination mechanism. ${ }^{427}$ One commentator interpreted this as a bid to indigenise security policy discourse in Asia to supplement or even replace the Western-managed Shangri-La Dialogue as the region's principal security dialogue. ${ }^{428}$ Indonesia and New Zealand have also cooperated on functional groupings like PAMS, which New Zealand attended in Jakarta in August 2008, and the Pacific Area Special Operations Conference.

\footnotetext{
${ }^{425}$ Foreign Affairs, Defence and Trade Committee, "2009/10 Financial Review of the New Zealand Defence Force (Question 1.49)."

${ }^{426}$ Viet Nam Ministry of Foreign Affairs, "First ADMM+ Chairman’s Statement."

${ }^{427}$ North Atlantic Treaty Organisation, “Jakarta International Defence Dialogue,” accessed January 29, 2013, www.nato.int/cps/ennatolive/news_71727.htm.

${ }^{428}$ Donald K. Emmerson, "Defense and Dialogue in Southeast Asia," Asia Times Online, March 27, 2012, http://www.atimes.com/atimes/Southeast_Asia/NC27Ae03.html.
} 


\section{Issues in Indonesia-New Zealand Defence Diplomacy}

While New Zealand's defence cooperation with China and Viet Nam have not proven to be controversial, defence cooperation with Indonesia continues to be highly contentious within New Zealand. The Indonesia case study provides three particularly illustrative examples of the dilemmas encountered; maintaining links with authoritarian regimes, applying conditions on those relations and striking a balance between 'old' and 'new' defence diplomacy.

\section{Purposes of Indonesia - New Zealand Defence Diplomacy and its Dilemmas}

The rationale for New Zealand's military cooperation with Indonesia can be found in the prevailing strategic context of each era. In the late 1960s through to the 1980s, communist insurgencies threatened much of South East Asia. In Indonesia itself, the military crackdown in 1965 took place in response to the growing influence of the Communist Party and the purge that followed killed an estimated 500,000 Communist Party members and sympathisers. Indonesia's annexation of East Timor in 1975 followed the expected rise to power of the left-wing FRETILIN party following the provinces' independence from Portugal. Western countries around the region were more concerned with the spread of communism than the internal policies of authoritarian governments like Indonesia. The end of the Cold War altered the strategic environment shaping the policies of Western governments, making them less willing to support authoritarian allies and pushing support for democracy further up the policy agenda. ${ }^{429}$

New Zealand defence cooperation was seen as a convenient way of creating other channels into a regime that was dominated by the military. ${ }^{430}$ Demonstrating an early grasp of the concept of 'new' diplomacy, NZDF officers recognised in 1981 the "valuable political spin-off from the defence relationship" which was an "excellent example of the way in which our armed forces could be used in support of our foreign policy objectives." ${ }^{431}$ Generating a favourable impression of New Zealand was also expected to bring wider benefits in terms of trade. ${ }^{432}$ New Zealand policymakers decided that defence

\footnotetext{
${ }^{429}$ Cottey and Forster, Reshaping Defence Diplomacy, 31.

${ }^{430}$ Green, "Uneasy Partners: New Zealand and Indonesia," 188.

${ }^{431}$ Pearce, MAP Visit to South East Asia 26 September to 11 October 1981.

${ }^{432}$ Ibid.
} 
was an important issue for Indonesia, so it made sense that New Zealand needed to understand the TNI and be able to engage with Indonesia about defence issues important to them both. ${ }^{433}$

From the outset, New Zealand officials expressed concerns about links with an authoritarian regime. In a diplomatic cable to the Jakarta embassy before the formalisation of relations, a New Zealand official noted a close relationship with Indonesia must be through the military for "they make the running of every aspect of Indonesian administration. Though we do not like this [...] it is the reality of political life," adding that there was "no alternative.",434

New Zealand public opinion of Indonesia had been poor since Sukarno's days were characterised by chaos and militarism. Suharto's regime, which began with large-scale killings and the detention of hundreds of thousands of political prisoners, was similarly repressive and authoritarian. From early on in the relationship, New Zealand civil society groups applied steady pressure on the government over the relationship with Indonesia. ${ }^{435}$ However, such issues did not tend to impair the development of bilateral relations. The attitude was summed up in a cable sent about the Defence Secretary's visit to Indonesia in 1974 which noted growing concerns about political prisoners; "not our business of course" but bound to make the concern known to Jakarta. The catalyst for change however was the annexation of East Timor, during which New Zealander Gary Cunningham and four other journalists were killed by Indonesian troops in Balibo, just after New Zealand military contacts were formalised. ${ }^{436}$

Concerns about the human rights record of the TNI in Timor grew, leading to disenchantment with the Suharto regime amongst both the public and officials. In the mid-1980s the NZDF dropped air weapons delivery training from the MAP syllabus following advice from the embassy in Jakarta that Skyhawks were being used against Timorese rebels. Two years later, MAP courses were limited to combat support and civic

\footnotetext{
${ }^{433}$ Centre for Strategic Studies New Zealand, Projecting Our Voice: Major Power Relationships in Asia, the Responses of Regional Organisations and the Implications for New Zealand. 3.

434 "Cable from Minister of Defence," April 12, 1973, Jakarta File 25/3/18.

${ }^{435}$ Green, "Uneasy Partners: New Zealand and Indonesia," 179.

${ }^{436}$ Leadbeater, Negligent Neighbour: New Zealand's Complicity in the Invasion and Occupation of TimorLeste, 52-57.
} 
aid training after Indonesian personnel trained in combat techniques by the New Zealand Army began operating in Timor. ${ }^{437}$

The purposes that had been put forward by New Zealand officials increasingly reflected the double standard that Cottey and Forster identified was inherent in Western defence diplomacy with authoritarian regimes. ${ }^{438}$ In the mid-1990s, defence officials defended defence links, arguing they would encourage the TNI to become more disciplined, professional and outwardly focused, and instil New Zealand democratic values in the TNI. ${ }^{439}$ Defence Minister Max Bradford, discussing the training of an Indonesian officer at the NZDF Defence College, said the officer would learn "the process of democratic government, the Geneva Convention and laws of armed conflict." ${ }^{440}$ Furthermore, the reasoning went, military links provided an opportunity to make our views known about human rights abuses by the military. However, there was very little evidence that New Zealand officials did pass on concerns about these matters. ${ }^{441}$

Advocates of military relations claimed that military engagement with the TNI was often misunderstood by the media and other government departments. ${ }^{442}$ For example, the purpose of Australian engagement with the TNI during the 1990s was described as providing a better understanding of the military and its role in the Indonesian government. It aimed to build the closest military relationship that was "morally possible."443 A former Australian Army Attaché to Indonesia stated that the relationship provided Australia with "great understanding, strategic leverage with our allies, and increased [our] overall strategic credibility." 444 Former Australian defence attaché to Indonesia Jim Molan argues cooperation with the TNI during the 1990s proved of much broader value by allowing the Australian government to make policy decisions about intervention in East Timor more confidently. ${ }^{445}$

\footnotetext{
${ }^{437}$ Green, "Uneasy Partners: New Zealand and Indonesia," 187.

${ }^{438}$ Cottey and Forster, Reshaping Defence Diplomacy, 31.

${ }^{439}$ Buchanan, New Zealand Military Cooperation with Indonesia, 5-6.

${ }^{440}$ Leadbeater, "New Zealand Trains Indonesia's Military," 13.

${ }^{441}$ Buchanan, New Zealand Military Cooperation with Indonesia, 6. 6.

${ }^{442}$ Floyd, Dropping the Autopilot: Improving Australia's Defence Diplomacy, 7.

${ }^{443}$ Ibid.

${ }^{444}$ Ibid.

${ }^{445}$ Ibid.
} 
In a similar manner, New Zealand Army officer Colonel Neville Reilly ensured the security of the United Nations Mission to East Timor (UNAMET) during the crisis, including pulling off several daring rescues of United Nations staff including a siege of the Mission's compound by militia forces. His ability to do so was aided by his diplomatic skills and Bahasa language ability, ${ }^{446}$ acquired during his time at Indonesian Staff College which gave him close links to senior TNI officers, including Lieutenant General Yudhoyono. ${ }^{447}$ Reilly's links with Yudhoyono, who would later become President, dated back to 1996, when they worked together as military observers in Bosnia. ${ }^{448}$ These links enabled Colonel Reilly to act, in the words of Chris Elder, "as an extremely effective and thoughtful operator" during his time as New Zealand Defence Attaché in Jakarta between 2000 and 2003. ${ }^{449}$

Most recently, similar arguments have been made to justify renewed links to the TNI. Proponents of defence links argue that TNI needs support in adjusting to its circumstances within a democratic state. Some analysts also point out that human rights are important, but often there are more compelling reasons for engagement. Writing in 1999, Australian analyst Paul Dibb wrote:

Human rights issues have an undeniably important place in international diplomacy, but are of little help at present to a vast nation such as Indonesia struggling to maintain its social and political cohesion. ${ }^{450}$

Cottey and Forster recognised defence diplomacy's lack of utility as a means of influencing civil-military relations in authoritarian regimes. Cottey and Forster argue that it was only those states that are reforming; that is those beginning democratic transitions or attempting to consolidate democratic gains, that are amenable to external influence. In these cases, they argued, defence diplomacy provides important political and practical support for the democratisation of civil-military relations. ${ }^{451}$ Cottey and Forster point out that, at the time of writing in 2004, Indonesia was a state "characterised by partial or stalled transitions, where elements of democratisation are in place, but the military

\footnotetext{
${ }^{446}$ New Zealand Defence Force, "Recipients of the New Zealand Gallantry Star" (New Zealand Defence Force, April 23, 2013), http://medals.nzdf.mil.nz/category/d/d3recipients.html.

447 Author's interview with Chris Elder, 27 March 2013.

${ }^{448}$ Ibid.

${ }^{449}$ Ibid.

${ }^{450}$ Paul Dibb, David D. Hale, and Peter Prince, “Asia’s Insecurity,” Survival 41, no. 3 (Autumn 1999): 15.

${ }^{451}$ Cottey and Forster, Reshaping Defence Diplomacy, 48.
} 
remains sufficiently powerful to resist further change." ${ }^{452}$ They conclude that while military engagement might be helpful, it was unlikely to achieve a decisive breakthrough.

Advocates of military cooperation argued that exercises and training with the NZDF encouraged the TNI to become more professional. Professionalism in a military sense played up the role of discipline, structure, order, self-sacrifice, as well as expertise in the application of force. By virtue of these attributes, professional military forces were considered more likely to accept civilian control. The TNI's former dwi fungsi role and self-funding model made it difficult to promote professionalism and encourage good civil-military relations. Consequently, the recent reforms of the TNI were likely to improve the ability of New Zealand defence diplomacy activities to impart this kind of professionalism.

Writing prior to the Timor crisis, Jim Rolfe described the cutting of defence links as an "overreaction" and said that "New Zealand will do better by working with Indonesia, and demonstrating that there are other, more effective ways of using the armed forces, than in shouting at her from a distance and being ignored." 453

\section{Reconciling the Indonesia - New Zealand defence relationship with the Five Power}

\section{Defence Arrangements}

The Five Power Defence Arrangements, which were examined in Chapter Three as a form of New Zealand's 'old' defence diplomacy, had their origins in Indonesian Konfrontasi, a policy directed against the post-colonial establishment of the Federation of Malaysia.

As early as 1968, New Zealand recognised the potential for military contacts to encourage Indonesia to continue to accommodate Malaysia and Singapore, as well as other Western countries, while discouraging any further foreign adventurism. ${ }^{454}$

Once the FPDA was established in 1971, a practical purpose for maintaining defence links, albeit one not acknowledged publicly, was to maintain Indonesian consent to use

\footnotetext{
452 Ibid., 31.

453 James Rolfe, “Why Shout at Soeharto?," New Zealand Defence Quarterly 16 (Autumn 1997): 16.

${ }^{454}$ Green, "Uneasy Partners: New Zealand and Indonesia," 176.
} 
their waters and airspace to transit to New Zealand's FPDA partners. ${ }^{455}$ Another objective of defence cooperation was to promote the idea that the Arrangements were not directed against Indonesia; something demonstrated by New Zealand's cooperative engagement. ${ }^{456}$

New Zealand considered the traditional relationship with the FPDA partners as more important than the relationship with Indonesia. ${ }^{457}$ Interestingly though, in the early $1980 \mathrm{~s}$ Ministry of Defence policymakers indicated a desire to "expand our MAP activities with Indonesia, even if this was to be at the expense of a slight reduction in the Malaysian and Singapore programmes." 458

Since 1971, the FPDA brought member countries together for regular military exercises and has served as a major confidence-building mechanism in the region. Most analysts agreed that the FPDA transformed some time ago from a collective security arrangement into a networking and confidence-building mechanism. However, it has continued to be viewed negatively by Indonesia because of the misperception that it is directed primarily against them. ${ }^{459}$ Indonesia has always tended to have a dim view of alliances involving external powers and, as a prominent member of ASEAN, it had little interest joining the Arrangements, in which it would have been a junior member. In 1990, a former Indonesian foreign minister called on the FPDA to be abandoned and replaced with a trilateral arrangement excluding the external powers. ${ }^{460}$ However, some military figures like former commander and Minister of Defence General Benny Moerdani, took a broader view of the Arrangements, arguing "if Malaysian and Singaporean security is enhanced by this arrangement, so is regional security."461 Overall, Indonesian officials seem to have had a similar view to that of New Zealand MFAT in the 1980s and 1990s, seeing the FPDA as having little practical relevance. ${ }^{462}$ Over time, ties with Singapore and Malaysia

\footnotetext{
${ }^{455}$ Ibid. 191

${ }^{456}$ Ibid., 188.

${ }^{457}$ McGibbon, "The Defence Dimension," 23.

458 "Letter from Doug Law, Assistant Secretary Policy, Ministry of Defence to New Zealand Ambassador Jakarta," December 13, 1982, JAK30/4/1.

${ }^{459}$ Chun Sing Chan, Whither a Common Security for Southeast Asia? (Fort Leavenworth, Kansas: US Army Command and General Staff College, 1998); Tim Huxley, "The Future of the Five Power Defence

Arrangements," The Strategist - Australian Strategic Policy Institute, November 2012, http://www.aspistrategist.org.au/.

${ }^{460}$ Rolfe, Anachronistic Past or Positive Future, 14.

${ }^{461}$ Rolfe, "Jousting with Jakarta," 11.

${ }^{462}$ Rolfe, Anachronistic Past or Positive Future, 14.
} 
have grown through ASEAN, while Australia and New Zealand have developed military links with Indonesia.

\section{Conclusion}

New Zealand's defence ties with Indonesia are somewhat paradoxical. While Indonesia has been a functioning democracy for some time, bilateral defence relations have proved more difficult to develop than those with China or Vietnam, due to the level of domestic political sensitivity. Comparing the number of defence activities with Indonesia to that with China and even Viet Nam over the same period reveals the clear limitations on the relationship. This is particularly significant when considering the numbers of Indonesian personnel visiting New Zealand for training and visits at the peak of the relationship in the 1980s.

Domestic opposition to improving defence diplomacy remains strong in New Zealand despite the progress made by Indonesia over the last decade in promoting democracy, good civil-military relations, and promoting respect for the rule-of-law and human rights amongst the military.

By arguing that military contacts encourage the TNI to respect democracy and human rights, New Zealand policy-makers invited the dilemma of having to choose between creating a double standard, and in doing so, accept criticism that its cooperation with Indonesia is not working, or cut off cooperation and lose what little influence they had with the regime. As Michael Green argued, the tendency of human rights groups to denounce defence links as complicity in repression and the tendency of defence and government officials to defend them as leverage on the Indonesian regime both overstated New Zealand's ability to influence Indonesia's behaviour. ${ }^{463}$

In New Zealand's case, it took the role played by the TNI in the post-ballot violence in East Timor and intervention by New Zealand forces in 1999 to finally put a halt to the relationship. What little influence New Zealand had over the government in Indonesia was then affected the by the loss of access to the Indonesian Staff College, which negatively impacted upon the ability of the new defence attaché to operate effectively.

${ }^{463}$ Green, "Uneasy Partners: New Zealand and Indonesia," 188. 
The success of defence diplomacy, or any form of strategic engagement for that matter, relies on being viewed as a long-term process of promoting change. Making cooperation linked too closely to short-term developments, made conditional on specific reforms, or broken off in the face of temporary setbacks will not result in success. Cottey and Forster argue that over the long-term, the process of strategic engagement may do more for human rights and democracy than short-term sanctions or the suspension of defence diplomacy, but the problem then becomes one of providing regimes with implicit support. Cottey and Forster claim that defence diplomacy can only be successful in delivering improved civil-military relations and professionalism in regimes that have already begun to reform. New Zealand's defence relations with Indonesia illustrate these dilemmas.

New Zealand's broader bilateral relationship with Indonesia is only likely to increase in importance into the future. However, the defence component of this relationship is likely to remain low key. Perhaps now, more than ever, is the time for New Zealand to be strengthening defence links with the TNI for the purpose of promoting democratic civilmilitary relations. The NZDF could offer training in laws of armed conflict and encourage and socialise respect for the rule of law and human rights. The Ministry of Defence could engage the TNI to provide advice on reforming and civilianising the management of defence policy, developing systems for management and control of the defence budget, and training civilian defence officials. Track II engagement could occur to encourage transparency, freedom of information and debate between defence-oriented civil society advocacy and campaigning groups.

Indonesia is keen to increase bilateral and multilateral defence diplomacy with New Zealand. Within New Zealand, foreign affairs and the military are also enthusiastic, but they remain aware of the strength of public opinion on the issue of human rights. For this reason, for the time being, an expansion of defence diplomacy seems unlikely to expand beyond limited education and training. The NZDF has no plans to establish a formal bilateral defence cooperation agreement, and point out that structural and financial resources did not currently permit any expansion of the bilateral cooperation programme. $^{464}$ While some kind of formal agreement around Indonesia-New Zealand

${ }^{464}$ Author's interview with Paul Sinclair, 28 November 2012. 
defence cooperation is a long-term goal, immediate priorities remain the initial steps needed to rebuild the relationship. A practical challenge will be to develop the defence relationship in ways that are in the interests of both countries.

New Zealand's experience with Indonesia also serves to demonstrate how bilateral relationships that lack strong foundations and public support can easily become hostage to single issues like human rights. As time goes on it will become increasingly important to resolve this issue to ensure that defence diplomacy activities can progress as Indonesia increases in strategic significance, not only to New Zealand, but amongst South East Asian nations. 


\section{Chapter Seven Conclusion}

This thesis has examined how New Zealand has used defence diplomacy - the idea that the military forces of a state can have a role in peacetime diplomacy and in conflict prevention and resolution. In 2004, Cottey and Forster questioned whether defence diplomacy was merely a transitional phase, a primarily European phenomenon in the immediate post-Cold War era. ${ }^{465}$ This thesis demonstrates that defence diplomacy has had application far beyond Europe and has had lasting relevance. It finds New Zealand has been receptive to the idea, perhaps because, as Gerald Hensley notes, in the absence of a direct threat, defence has generally been seen as one dimension of the country's broader foreign policy.

One of the aims of this study was to determine whether New Zealand's defence relations had significantly changed in the post-Cold War period. This thesis finds that New Zealand adopted defence diplomacy well before the term itself was coined. The early employment of the concept in the immediate post-Cold War era reflected the changing nature of New Zealand's security interests. The country has traditionally used its military to fight wars overseas and to ensure its interests were taken into account by its major allies. Prior to the Second World War, the key partner was Britain. Between 1945 and the mid-1980s it increasingly became the United States. In the post-Cold War world, however, security increasingly meant constructing a spider web of bilateral and multilateral linkages with allies, partners but also non-like-minded states to ensure New Zealand's views were heard. For new Asian partners like China and Viet Nam, a military-to-military relationship was one of a range of links that complemented growing bilateral political and economic ties. As New Zealand's economic relations became more open and varied, so too New Zealand's defence and foreign policies have changed and moved away from a focus on alliance management and territorial defence to broader regional security engagement.

New Zealand was not only an early adopter of defence diplomacy, it was also an enthusiastic one. New Zealand commenced defence ties with a range of new partners in 1998 and since that time has greatly expanded the range and frequency of contacts. Defence relationships that began with the exchange of attachés and perhaps one high-

${ }^{465}$ Cottey and Forster, Reshaping Defence Diplomacy, 13. 
level visit each year have expanded over the space of just over a decade to a regular series of strategic dialogues, high-level exchanges, ship visits, educational links, interactions at multilateral fora and military exercises. The momentum shows no signs of abating either, with the announcement of new defence links with India in 2011 and the prospect of combat exercises with China mooted. ${ }^{466}$

Examining the development of New Zealand's defence ties with new partners, there is evidence that much of the initiative and the pace of progress has been driven by them. For example, China seems to have used the NZDF as an incubator or test case for engagement with larger Western military forces. New Zealand is seen by the Chinese as a Western democracy, but one that is small, unthreatening and where missteps will be overlooked. In the Viet Nam case, defence engagement seems to have been driven by Viet Nam's growing sense of itself as an active and responsible regional player. In both these cases New Zealand has proved happy to reciprocate and sees advantages of its own from military-to-military ties. It clearly benefits from high-level access to defence policy makers in Asia and the opportunity to exchange views on regional security issues. New Zealand's interest in defence ties is therefore arguably less to do with any intrinsic value in narrow defence terms, and more because it shares with its new partners the desire to have defence ties as part of a comprehensive political relationship. As Tony Browne puts it, "If China is going to be engaging with a country in a significant manner, they will expect there to be a defence component." ${ }^{467}$ The armed forces of China, Viet Nam and Indonesia are significant political actors in their countries; as a result, the military dimension of the bilateral relationship seems to be more important to these countries than it is to New Zealand.

In contrast, New Zealand foreign affairs and defence officials see military ties as supporting broader foreign policy objectives. The primacy of broader foreign policy objectives over military-to-military links was illustrated by MFAT's reluctance to recommend an RNZN ship visit to Da Nang, a Vietnamese naval base, in deference to a visit to Ho Chi Minh City in support of New Zealand commercial and consular interests. Interviews with senior Defence and Foreign Affairs officials in New Zealand suggest that

\footnotetext{
${ }^{466}$ Author's interview with Dr Wayne Mapp, 14 March 2013.

${ }^{467}$ Author's interview with Tony Browne, 11 March 2013.
} 
defence diplomacy is really about the high-level contacts needed for the purposes of broader strategic engagement.

There are, however, subtle differences in the way Defence and Foreign Ministry actors perceive defence diplomacy. It is possible to discern from New Zealand doctrine and to glean from conversations with NZDF personnel that the Defence Force sees defence cooperation as helping to build confidence between potential foes and assist those countries struggling to build capacity and improve governance. It is a way of establishing personal relationships through which greater understanding can be forged. In times of crisis, this understanding can help to reduce misinterpretations of the other side's motivations and actions and open channels of communication, something that proved to be invaluable for Defence Force attaché Neville Reilly in East Timor. For the NZDF, defence diplomacy entails undertaking activities that enhance shared understanding, and build linkages and lines of communication between dissimilar forces. ${ }^{468}$ None of the MFAT officials interviewed for this thesis saw defence diplomacy in such ambitious terms.

Unlike the original British concept, New Zealand's defence diplomacy in Asia has not often been about promoting democracy and respect for human rights. New Zealand simply does not have the resources to engage with and assist military forces in post democratic or post-conflict societies. Officials in New Zealand's foreign policy and defence sector frequently refer to the power of visits and exchanges between defence forces to assist in the development of positive norms, like improved civil-military relations for example, in those forces being engaged. In practice however, there is little evidence to suggest that defence links achieve these goals in Asia. For a start, New Zealand never sought to influence the PLA or VPA in this way. Concerns about human rights are always pursued through other diplomatic channels. As the Indonesian case demonstrated, defence ties with authoritarian regimes are often justified in terms of their ability to influence those in power and the behaviour of their military. Claiming to seek improved respect for democracy and human rights via defence ties with the Suharto regime in Indonesia simply invited accusations of double standards. Opponents of defence links inevitably labelled these assertions to be hypocritical.

\footnotetext{
${ }^{468}$ New Zealand Defence Force, New Zealand Defence Doctrine Publication (NZDDP) - D Foundations of New Zealand Military Doctrine 2008.
} 
New Zealand's defence diplomacy does not feature a great deal of explicit conditionality, but it does occur. While New Zealand and our new partners do not have deep strategic differences that complicate the relationship, public opinion has proved to be a factor in defence relations with certain countries. In terms of the case studies explored here, domestic political concerns led New Zealand to suspend its defence relations with Indonesia as a result of the actions of the TNI. Concerns about TNI complicity in human rights abuses had been simmering away for years, and were acknowledged by officials, but these had little discernible effect on defence relations until violence broke out in East Timor in 1999. When comparisons are drawn between Indonesia on the one hand and China and Viet Nam, states that have their own issues with human rights, on the other, it might be concluded that it is only where the military can be directly linked to human rights abuses or interference with democratic political processes that it becomes an issue for New Zealand. The particularly problematic relationship with the TNI also reflects the influence of well organised New Zealand groups focused on Indonesia, East Timor and West Papua. ${ }^{469}$

There is a paradox here. Defence ties with Indonesia have proven hardest to maintain at a time when that country has been a vibrant democracy. Meanwhile, growing military ties with authoritarian China and Viet Nam have passed with almost no comment.

A final aim of this study was to determine whether New Zealand's defence diplomacy fulfils similar roles to those of other states such as the United Kingdom, where the concept was first articulated. In their seminal study, Cottey and Forster identified two patterns of defence diplomacy. The first is defence cooperation between established democracies, underpinned by shared threats and common values, together with cooperation between Western democracies and allies of convenience, most notably in the 'War on Terror'. The second is strategic engagement with former or potential enemies in order to prevent conflict and improve wider political relations and support to states undergoing major domestic change, in particular democratisation and post-conflict

\footnotetext{
${ }^{469}$ It should also be noted that the NZDF suspended defence cooperation with Thailand through the Military Assistance Programme in 2008, following domestic unrest in that country which saw the military suppress protestors in the capital city.
} 
reconstruction. ${ }^{470}$ As we saw in Chapter Three, the analytical framework developed by Cottey and Forster can be readily applied to New Zealand's practice and provides a useful way of conceptualising New Zealand's myriad forms of defence cooperation. At the root of 'old' defence diplomacy lies the requirement to prepare for the use of force; in this case the development of another country's military to both defend themselves and operate alongside New Zealand. Meanwhile, the basis for 'new' defence diplomacy is conflict prevention through bilateral and multilateral engagement. New Zealand's approach to defence diplomacy tends to fall somewhere between these two patterns. New Zealand defence relations with China, Viet Nam and Indonesia reflect the underlying goal of 'old' defence diplomacy designed to enhance the collective ability to deal with common threats. In these cases, the common threats are the emerging non-traditional security issues such as terrorism, piracy and humanitarian assistance / disaster relief. While their domestic political systems might differ, New Zealand, China, Viet Nam and Indonesia have overlapping interests in some of these areas.

That notwithstanding, these new military relationships remain complicated by traditional balance of power concerns and the preservation of military capability. As former Defence Minister Wayne Mapp puts it, these are not values-based relationships. ${ }^{471}$ Because of this, the ability of these new defence ties to grow and deepen far beyond their present state must remain doubtful.

${ }^{470}$ Cottey and Forster, Reshaping Defence Diplomacy, 70.

${ }^{471}$ Author's interview with Dr Wayne Mapp, 14 March 2013. 


\section{Appendix One Interview Information}

\section{Participant Information Sheet}

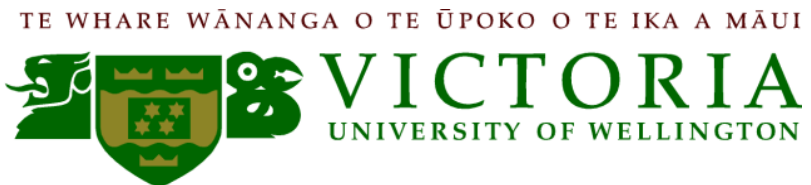

\section{PARTICIPANT INFORMATION SHEET}

Researcher: Justin Fris: School of History, Philosophy, Political Science and International Relations, Victoria University of Wellington.

I am a student at Victoria University of Wellington undertaking a Master of Arts in International Relations. To complete this degree I am writing a thesis focused on analysing New Zealand's military engagement with the armed forces of former and potential adversaries.

As part of my research I am interviewing past and present politicians and government officials involved in the development and conduct of New Zealand's military relations with a range of armed forces in Asia. If you agree to participate in this research, it is envisaged that the interview will take approximately 30 minutes to complete. During the interview I will ask a series of questions about how and why the military relationships developed and the issues that arose. I am happy to attend your place of work or your home for the interview.

I have obtained ethics approval from the University for this interview. Participation in this project is voluntary and you may choose whether or not to answer any particular question(s).

Where interviews are audio recorded and transcribed, a transcript of the interview will be made available to you for your approval. If requested, your audio recording can be returned to you at the conclusion of the project. All hard copy recordings and transcripts will be kept in a locked cabinet only accessible by me. Any electronic information will be kept in a password-protected file with access limited to me. No other person will hear the audio recording or see the interview transcripts other than my supervisors. Recordings will be deleted at the conclusion of the project, while all transcripts will be destroyed two years after the end of the project.

Should you feel the need to withdraw from the project, you may do so without question prior to 30 April 2013. Please contact me if this is the case.

The information collected during the interview will contribute to my thesis. Individual quotes from interviews may be used in the final thesis. If so, they will be attributed to the participant. The final thesis will be submitted for marking to the School of History, Philosophy, Political Science and International Relations. A copy can be made available to participants if requested. The final thesis will also be deposited at the Victoria University Library.

If you have any questions or would like to receive further information about the project please contact me at frisjust@myvuw.ac.nz or phone 04496 0536. Alternatively, you may contact either of my supervisors, Dr David Capie or Prof Robert Ayson, at the School of History, Philosophy, Political Science and International Relations at Victoria University, PO Box 600, Wellington. They can be contacted at david.capie@vuw.ac.nz, rob.ayson@vuw.ac.nz, or phone 044637483 or 044636445 respectively.

Justin Fris

Signed: 


\section{Interview Questions}

1. Why does New Zealand have defence links with country $\mathrm{x}$ ?

2. How did the defence relationship with country x come about?

3. During the development of the defence relationship with country $\mathrm{x}$, was there a set path followed?

4. What does New Zealand get out of the defence relationship?

5. What do you believe country $\mathrm{x}$ gets out of the defence relationship?

6. How is the defence relationship with country $\mathrm{x}$ coordinated with New Zealand's wider foreign policy objectives towards the country? Are there any issues regarding primacy i.e. which agency decides the parameters of the relationship?

7. Has the defence relationship with country $x$ been impacted by New Zealand domestic opinion, and if so, how?

8. Has New Zealand applied any form of conditionality to the relationship with country $\mathrm{x}$ ?

9. Are there any limits to expanding the defence relationship in future? If there are none, or they are minor, what form do you think our future relationship will take, and why do you think it will take this form?

10. How do you manage the balance between bilateral and multilateral defence diplomacy? Is there any preference for one over the other?

11. What do you seek out the relationship? Is this dependent on what you receive from the relationship? 


\section{Participant Consent Sheet}

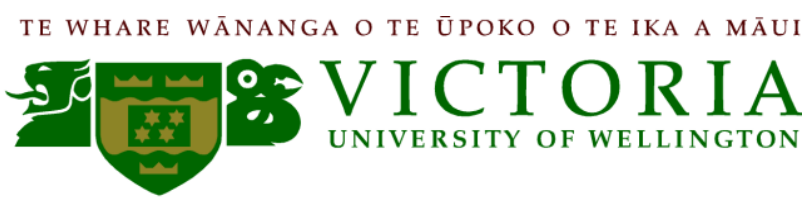

\section{CONSENT TO PARTICIPATION IN RESEARCH}

Title of Project: New Zealand's Defence Diplomacy in Asia

Researcher: Justin Fris: School of History, Philosophy, Political Science and International Relations.

I have been given and have understood an explanation of this research project. I have had an opportunity to ask questions and have them answered to my satisfaction. I understand that I may withdraw myself (or any information I have provided) from this project before 31 March 2013 without having to give reasons.

Please tick the boxes below as appropriate:

I consent to information or opinions that I have given being attributed to me in any reports on this research, OR:

$\square \quad$ I consent to information or opinions that I have given being used on the condition of anonymity in any reports on this research.

$\square \quad$ I would like the tape recordings of my interview returned to me / deleted at the conclusion of the project.

$\square \quad$ I understand that I will have an opportunity to check the transcripts of the interview before publication.

$\square \quad$ I understand that the data I provide will not be used for any other purpose or released to others without my written consent.

I would like to receive a summary of the results of this research when it is completed.

I agree to take part in this research.

Signed:

Name of participant:

(please print clearly)

Date: 


\section{Bibliography}

Acharya, Amitav. "A Survey of Military Cooperation Among the ASEAN States: Bilateralism or Alliance? Occasional Paper No. 14." Centre for International and Strategic Studies, May 1990.

—. "Regional Institutions and Regional Security Order: Norms, Power and Prospects for Peaceful Change." In Asian Security Order: Instrumental and Normative Features. Stanford, Calif.: Stanford University Press, 2003.

Aditya Singh. "Military Diplomacy.” Defence and Security Alert, January 2011. http://www.dsalert.org/january-2011/172-military-diplomacy-written-by-gen-adityasingh.

AFP News Agency. "Vietnam to Reopen Cam Ranh Bay to Foreign Fleets: PM." Bangkok Post, October 31, 2010, sec. Asia.

Agence France-Presse. "US, Vietnam Start First Military Relationship.” Yahoo.com, August 1, 2011.

Allen, Kenneth, and Emma Kelly. "Assessing the Growing PLA Air Force Foreign Relations Program.” China Brief 12, no. 9 (April 26, 2012). http://www.jamestown.org/uploads/media/cb_04_06.pdf.

Allen, Kenneth, and Eric A. McVadon. China's Foreign Military Relations. Washington D.C.: Henry L. Stimson Center, 1999.

Amer, Ramses. "Vietnam in 2010: Regional Leadership." Asian Survey 51, no. 1 (2011): 196-201.

Asia Pacific Centre. "Report from the Conference on Evolving Roles of the Military in the Asia-Pacific." Honolulu, Hawaii, 2000.

http://www.apcss.org/Publications/Report_Evolving_Roles.html.

Australia Network. "Interview with Marty Natalegawa, Indonesia's Foreign Minister." Accessed January 28, 2013. http://australianetwork.com/focus/s3440427.htm.

Australia. Dept. of Defence. Defending Australia in the Asia Pacific Century: Force 2030 : Defence White Paper 2009. [Canberra]: Dept. of Defence, 2009.

Australian Department of Defence. Strategic Review 1993. Commonwealth of Australia, 1993. http://www.defence.gov.au/oscdf/se/publications/stratreview/1993/1993_Part1.pdf.

Author's interview with CDR Shaun Fogarty, 12 December 2012.

Author's interview with Chris Elder, 27 March 2013.

Author's interview with Dr Wayne Mapp, 14 March 2013.

Author's interview with Gerald Hensley, 22 March 2013.

Author's interview with John McKinnon, 7 March 2013. 
Author's interview with Paul Sinclair, 28 November 2012.

Author's interview with senior MFAT official, 15 February 2013.

Author's interview with senior MFAT official, 26 February 2013.

Author's interview with Tony Browne, 11 March 2013.

Ayson, Robert. "Force and Statecraft: Strategic Objectives and Relationships in New Zealand's 2010 Defence White Paper.” Security Challenges 7, no. 1 (Autumn 2011).

Ayson, Robert, and Chris Elder. China's Rise and New Zealand's Interests: A Policy Primer for 2030. Discussion Paper 11. Wellington, N.Z.: Centre for Strategic Studies, 2012.

Badie, Bertrand, Dirk Berg-Schlosser, Leonardo Morlino, and inc Sage Publications. International Encyclopedia of Political Science. Thousdand Oaks, Calif.: SAGE, 2011.

Baldwin, Donald. Chinese Strategic Development: Regional Dominance through Global Influence. Carlisle Barracks PA: U.S. Army War College, 2009.

Barratt, Joseph. "Ties with Indonesia Quietly Renewed.” Te Waha Nui Online, June 1, 2007. http://www.tewahanui.info/news/070601_Indonesia.shtml.

Bates, Gill. Rising Star: China's New Security Diplomacy. Washington, D.C.: Brookings Institution Press, 2007.

Bearman, Sidney, ed. "New Challenges to Defence Diplomacy." Strategic Survey 1999/2000 100, no. 1 (January 1999): 38-53.

Berridge, Geoffrey R. Talking to the Enemy: How States Without "Diplomatic Relations" Communicate. Houndmills: Macmillan, 1994.

Berridge, Geoffrey R, and A James. A Dictionary of Diplomacy. Basingstoke: Palgrave, 2001.

Bin Rashid, Azmi. "Defence Diplomacy: Meeting Future Challenges." Asian Defence Journal no. 9 (1999).

Bjornar Lunde. "The Dilemma of Smaller European Nations: Rethinking Future Military Cooperation and Capability Development." United States Marine Corps Command and Staff College, 2008.

Blaxland, John. "Myanmar: Time for Australian Defence Cooperation.” Security Challenges 7, no. 4 (Summer 2011): 61-76.

Bodeen, Christopher. "Chinese Military Launches New Weapon: Charm.” Army Times, October 21, 2011.

Bōeichō Bōei Kenkyūjo (Japan). East Asian Strategic Review, 2005. Tokyo: National Institute for Defense Studies, 2005. 
Boeisho Boei Kenkyujo (Japan). Asia Pacific Countries' Security Outlook and Its Implications for the Defence Sector. Tokyo: The National Institute for Defense Studies, 2010 .

Bradford, Max. "New Zealand Suspends Military Co-Operation with Indonesia." Releases, September 10, 1999. http://www.beehive.govt.nz/release/new-zealandsuspends-military-co-operation-indonesia.

“Brief for Prime Minister's Visit to Indonesia 25-30 May 1980," May 13, 1980. Jakarta File 30/4/1.

Bryden, Alan, and Heiner Hanggi. "Reforming and Reconstructing the Security Sector." In Security Governance in Post-Conflict Peacebuilding, edited by Alan Bryden and Heiner Hanggi. Geneva, Switzerland: Geneva Centre for the Democratic Control of Armed Forces, 2005.

Buchanan, Joe. New Zealand Military Cooperation with Indonesia. Wellington, N.Z.: Peace Movement Aotearoa, 1995.

Bureau of Public Affairs Department Of State. The Office of Electronic Information. "2010 Human Rights Report: Burma," April 8, 2011. http://www.state.gov/g/drl/rls/hrrpt/2010/eap/154380.htm.

Butcher, Andrew. Beyond Soldiers, Students and Sentiment: New Zealand, Southeast Asia and ASEAN. Outlook 2012. Asia: New Zealand Foundation, 2012.

Butcher, Andrew, and Terence O’Brien. Audio Interview by John Saunders. Audio, May 2012. http://www.asianz.org.nz/sites/asianz.org.nz/files/Asia\%20NZ\%20ASEAN\%20Small.mp 3.

C. Raja Mohan. "Military Diplomacy." The Indian Express, n.d., 18 August 2010 edition. Accessed January 13, 2011.

“Cable from Minister of Defence,” April 12, 1973. Jakarta File 25/3/18.

“Cable from NZDEFJAK to NEWFORSEA,” May 10, 1984. Jakarta File 30/4/1.

Canada Department of National Defense. "Defence Policy Statement.” In Canada's International Policy Statement: a Role of Pride and Influence in the World. Ottawa: Government of Canada, 2005.

Capie, David. 'Structures, Shocks and Norm Change: Explaining the Late Rise of Asia's Defence Diplomacy." Contemporary Southeast Asia 35, no. 1 (April 2013).

Capie, David, and Paul Evans. The Asia Pacific Securty Lexicon. 2nd ed. Singapore: Institute of Southeast Asian Studies, 2007.

Capie, David, and Brendan Taylor. "The Shangri-La Dialogue and the Institutionalization of Defence Diplomacy in Asia." The Pacific Review 23, no. 3 (2010): 359-376. 
CCTV News. CCTV Exclusive Interview with NZ Defense Minister, 2010. http://english.cntv.cn/program/newsupdate/20100913/101049.shtml.

Chairman of the Joint Chiefs of Staff. National Military Strategy of the United States of America: Shape, Respond, Prepare Now: A Military Strategy for a New Era. Washington D.C.: United States Joint Staff, 1997.

Chandrasekaran, Rajiv. "Indonesian Military Tied to Recent Timor Attacks." Washington Post, March 20, 2000. http://www.library.ohiou.edu/indopubs/2000/03/20/0021.html.

Chau, Wilson Chun Hei. "Explaining China's Participation in Bilateral and Multilateral Military Exercises." Security Challenges 7, no. 3 (Spring 2011) (September 2011): 5169.

“China to Boost Military Talks with Countries." China Daily, October 31, 2012. http://eng.mod.gov.cn/DefenseNews/2012-10/31/content_409957.htm.

Chow, Jermyn. "Army Chiefs Here For Security Talks: China and Laos Taking Part for First Time Since Defence Summit Began in 1999." Singapore Straits Times, July 29, 2011, sec. B10.

Chris Elder. "Defence in International Relationships." Ministry of Foreign Affairs and Trade Record (October 1999): 11-14.

Chun Sing Chan. Whither a Common Security for Southeast Asia? Fort Leavenworth, Kansas: US Army Command and General Staff College, 1998.

Claire Taylor, Tom Waldman, and Sophie Gick. British Defence Policy Since 1997. Research Paper 08/57. London: House of Commons Library, 2008.

Coleman, Peter. "The Value of Defence Relationships.” One Force no. 5 (October 2010). http://www.nzdf.mil.nz/news/publications/one-force/5/value-of-defencerelationships.htm.

Conboy, Kenneth. Kompassus - Inside Indonesia's Special Forces. Jakarta: Equinox Publishing, 2003.

Cooke, Peter. Report on Medallic Recognition of New Zealand Military Service in SouthEast Asia 1950-1975. Wellington, N.Z.: New Zealand Defence Force, 2011. http://medals.nzdf.mil.nz/seasia/documents/jul2011-seasiafullreport1950-1975.pdf.

Cottey, Andrew, and Anthony Forster. Reshaping Defence Diplomacy : New Roles for Military Cooperation and Assistance. Adelphi Papers 365. Oxford; New York: Oxford University Press for the International Institute for Strategic Studies, 2004.

Council on Foreign Relations. "A Conversation with Marty Natalegawa, Minister of Foreign Affairs, Republic of Indonesia," September 20, 2010.

http://www.cfr.org/indonesia/conversation-marty-natalegawa-minister-foreign-affairsrepublic-indonesia/p22984.

David Dickens. "Return to Credibility." New Zealand International Review 23, no. 2 (April 1998): 15-17. 
Daws, Gavin. Prisoners of the Japanese : Pows of World War II in the Pacific. William Morrow Paperbacks, 1996.

Deane, Roderick. Value for Money Review of New Zealand Defence Force. Wellington N.Z.: Pacific Road Group, 2010.

Defence Attache. Defence Cooperation with Indonesia, June 1, 1974. Jakarta File 30/4/1.

Defence Committee of Enquiry (New Zealand). Defence and Security: What New Zealanders Want : Report of the Defence Committee on Enquiry. Wellington: V.R. Ward Government printer, 1986.

Defence Policy and Planning Unit. Maritime Forces Review: Key Findings. Wellington, N.Z.: New Zealand Ministry of Defence, 2002.

Dempsey, Adam. A Friend in Need: Vietnam's Contemporary Defence Policies. Regional Studies. U.K. Defence Forum, April 2010.

http://www.ukdf.org.uk/assets/downloads/RS73Afriendinneed-

Vietnam\%E2\%80\%99scontemporarydefencepolicies.pdf.

Department of Defence. Defence 2000: Our Future Defence Force. Parliamentary Paper 451. Canberra: Defence Publishing Service, 2000.

. Defending Australia in the Asia Pacific Century: Force 2030. Canberra:

Commonwealth of Australia, 2009.

Department of the Army. US Army Field Manual 3-0, Operations. Washington D.C.: United States Army, 2001.

Derek Quigley. “The Evolution of New Zealand Defence Policy.” Security Challenges 2, no. 3 (October 2006): 41-61.

Dibb, Paul. Defence Strategy in the Contemporary Era. Canberra, Australia: Strategic and Defence Studies Centre, Australian National University, 1999.

. The Review of Australia's Defence Capabilities. Canberra: Australian Government Publishing Service, 1986.

Dibb, Paul, David D. Hale, and Peter Prince. “Asia's Insecurity.” Survival 41, no. 3 (Autumn 1999).

_. "The Strategic Implications of Asia's Economic Crisis." Survival 40, no. 2 (Summer 1998).

Dickens, David. Inquiry into Defence Beyond 2000: An Independent Review of the Foreign Affairs, Defence and Trade Parliamentary Select Committee's Interim Report. Working Paper 13/99. Wellington, N.Z.: Centre for Strategic Studies, 1999.

Lessening the Desire for War: The ASEAN Regional Forum and Making of Asia Pacific Security. Working Paper 11/98. Wellington: Centre for Strategic Studies, Victoria University of Wellington, 1998.

http://www.victoria.ac.nz/css/docs/working_papers/wp11.pdf. 
Don McKinnon. "Building International Linkages: The Contribution of the Defence Force.” Ministry of Foreign Affairs and Trade Record 2, no. 10 (April 1994): 14-17.

Du Plessis, Anton. "Defence Diplomacy: Conceptual and Practical Dimensions with Specific Reference to South Africa.” Institute for Strategic Studies, 2008.

Elder, Chris. "Gaining a Voice: a Small Power's Strategy.” New Zealand International Review 34, no. 4 (August 2009).

Elleman, Bruce. "Sino-Soviet Relations and the February 1979 Sino-Vietnamese Conflict." Lubbock, Texas: The Vietnam Center and Archive, 1996. http://www.vietnam.ttu.edu/events/1996_Symposium/96papers/elleviet.htm.

Ellingham, Jimmy. "Pilot Training Tipped for Ohakea." Manawatu Standard, January 8, 2010. http://www.stuff.co.nz/manawatu-standard/news/3215019/Pilot-training-tipped-forOhakea.

Emmers, Ralf. The Role of the Five Power Defence Arrangements in the Southeast Asian Security Architecture. RSIS Working Paper 195. S. Rajaratnam School of International Studies, 2010. http://www.rsis.edu.sg/publications/WorkingPapers/WP195.pdf.

Emmerson, Donald K. "Defense and Dialogue in Southeast Asia." Asia Times Online, March 27, 2012. http://www.atimes.com/atimes/Southeast_Asia/NC27Ae03.html.

Evaluation Division. Review of Defence Attaches and Advisors. 2002 8. Wellington, N.Z.: New Zealand Ministry of Defence, 2002.

Federal Ministry of Defence. White Paper on the Security of the Federal Republic of Germany and the Situation and Future of the Bundeswehr. Bonn: Press and Information Office of the Federal Government, 1994. http://www.resdal.org/Archivo/Falem-cap1.htm.

Feng Zhang. "China's New Thinking on Alliances." Survival 54, no. 5 (November 2012): 129-148.

FForde, Adam. "Vietnam in 2011: Questions of Domestic Sovereignty." Asian Survey 52, no. 1 (2012): 176-185.

Floyd, Nicholas. Dropping the Autopilot: Improving Australia's Defence Diplomacy. Policy Brief. Sydney: Lowy Institute for International Policy, 2010. www.lowyinstitute.org/Publication. asp?pid=1459.

Foreign Affairs, Defence and Trade Committee. 2007/08 Financial Review of the New Zealand Defence Force(Response to Questions). New Zealand Parliamentary Service, 2009. http://www.parliament.nz/NR/rdonlyres/B5B58203-25D5-438C-A58EF0C31AB9EE45/207306/49SCFDT_EVI_00DBSCH_FIN_8721_1_A45787_NewZealan dDe.pdf.

“2008/09 Financial Review of the New Zealand Defence Force(questions 2025)." New Zealand Parliamentary Service, December 10, 2009. http://www.parliament.nz/NR/rdonlyres/3A3D56E1-04DA-468A-B542282AA3DB0D26/207272/49SCFDT_EVI_00DBSCH_FIN_9382_1_A25197_NewZeala ndDe.pdf. 
"2009/10 Estimates Vote Defence Force (Response to Supplementary Questions 1-27)." New Zealand Parliamentary Service, June 25, 2009.

http://www.parliament.nz/NR/rdonlyres/5C4A4B92-1389-4DC5-97DD-

04FD2D1E714B/207153/49SCFDT_EVI_00DBSCH_EST_9178_1_A37095_Ministerof De.pdf.

. "2009/10 Financial Review of the New Zealand Defence Force (Question 1.49)." New Zealand Parliamentary Service, n.d.

http://www.parliament.nz/NR/rdonlyres/6CF16F03-FF67-4A62-A7ED-

9445908CE9B4/207195/49SCFDT_EVI_00DBSCH_FIN_10188_1_A162886_NewZeala nd.pdf.

"2010/11 Estimates for Vote Defence Force (Supplementary Question 2.1-2.40 Vote Defence Force)." New Zealand Parliamentary Service, June 24, 2010. 18 February 2013.

_. "2010/2011 Financial Review - Vote Defence Force.” New Zealand

Parliamentary Service, November 18, 2010.

http://www.parliament.nz/NR/rdonlyres/9EBA29AA-5605-419A-A364-

5307267FC7D3/166703/49SCFDT_EVI_00DBSCH_FIN_10188_1_A150812_NewZeala nd.pdf.

“2011/2012 Estimates for Vote Defence Force.” New Zealand Parliamentary Service, n.d. http://www.parliament.nz/NR/rdonlyres/9AF7C261-C4FC-447B-AE18FCFC0D03AEA0/207101/49SCFDT_EVI_00DBSCH_EST_10656_1_A197589_Ministe rof.pdf.

Foreign Affairs, Defence and Trade Select Committee. "Supplementary Questions, List 2 - 2007/2008 Estimates: Vote Defence Force.” New Zealand Parliamentary Service, n.d.

Frank Wilson. Indonesia and Its Significance for New Zealand. Outlook 2012 Series. Wellington N.Z.: Asia New Zealand Foundation, May 2012.

Freeman Jr, Chas. W. Diplomat's Dictionary. 2nd edition. United States Institute of Peace Press, 2010.

Fuseworks Media. "Chinese Ships to Visit Auckland," September 10, 2010.

http://www.voxy.co.nz/national/chinese-ships-visit-auckland/5/62657.

Gangadharan, Surya. "US Courts India, Says Sensitive Weapons Tech Deals No Taboo." India Global, July 24, 2012. http://ibnlive.in.com/news/us-courts-india-says-no-taboo-onsensitive-weapons-tech/274093-61.html.

Gentles, Dick. "New Zealand Defence Policy: Has It Been Transformed? Dick Gentles Finds Some New Developments That Seem to Represent a Transformation of New Zealand's Approach to Defence." New Zealand International Review 30, no. 4 (2005): $7-$ 11.

Gertz, Bill. "Chinese Communists Influence U.S. Policy Through Ex-Military Officials." The Washington Free Beacon, February 6, 2012. http://freebeacon.com/chinesegovernment-influencing-policy-through-ex-military-officials/. 
"Chinese to View Sensitive U.S. Sites: Lawmaker Sees Violation." The Washington Times, May 18, 2011.

Gill, Bates. Rising Star: China's New Security Diplomacy. Washington D.C.: Brookings Institution Press, 2007.

Grant Cowley. “A Missed Opportunity.” New Zealand International Review 23, no. 2 (April 1998): 10-14.

Grattan, Robert F. Strategic Review: The Process of Strategy Formulation in Complex Organisations. Farnham, UK: Gower Publishing, Ltd., 2011.

Green, Michael. Indonesia's Armed Forces in the Democratic Era. Strategic Briefing Papers. Centre for Strategic Studies, Victoria University of Wellington, November 2011. http://www.victoria.ac.nz/css/Strategic_Briefing_Papers/Vol.6\%202011/Indonesia\%27s\% 20Armed\%20Forces\%20SBP\%20Vo16\%20P1\%20Nov2011.pdf.

_. "Uneasy Partners: New Zealand and Indonesia." In Southeast Asia and New Zealand: A History of Regional and Bilateral Relations, edited by Anthony L. Smith. Singapore: Institute of Southeast Asian Studies, 2005.

Greg, Greg Ansley Email. “Archives Reveal Threats over Timor.” New Zealand Herald, January 2, 2012, sec. World.

http://www.nzherald.co.nz/world/news/article.cfm?c_id=2\&objectid=10776233.

Grevatt, Jon. "US and Vietnam Agree Closer Co-operation.” Jane's Defence Weekly, January 23, 2012.

Gunness, Kristen. “China's Military Diplomacy in an Era of Change.” Fort Lesley J. McNair: National Defense University, 2006.

Heidi Holz, and Kenneth Allen. "Military Exchanges with Chinese Characteristics: The People's Liberation Army Experience with Military Relations." In The PLA at Home and Abroad: Assessing the Operational Capabilities of China's Military, edited by Roy Kamphausen, David Lai, and Andrew Scobell, 429-473. Carlisle, PA :: Strategic Studies Institute, U.S. Army War College,, 2010.

Hensley, Gerald. “Asia-Pacific Security: Paradox and Riddle.” New Zealand International Review 23, no. 1 (February 1998).

_. "New Zealand's Defence in the 1990s." New Zealand International Review 17, no. 3 (June 1992).

Hill, Matthew. "Chessboard or 'Political Bazaar'? Revisiting Beijing, Canberra and Wellington's Engagement with the South Pacific." Security Challenges 6, no. 3 (Spring 2010): 41-58.

Hilliam-Kareko, Patricia. "Vietnamese Officers Learn the Kiwi Way.” Army News, November 2011.

Hills, Alice. "Defence Diplomacy and Security Sector Reform." Contemporary Security Policy 21, no. 1 (2000): 46-67. 
Hoadley, Stephen. "From Defence to Security: New Zealand's Hard Power, Soft Power, and Smart Power." New Zealand International Review 32, no. 5 (September 2007): 18+.

Holslag, Jonathan. Trapped Giant: China’s Troubled Military Rise. Routledge, 2011.

Huang Guifang. "Promoting China-New Zealand Relations Towards the 21st Century." In New Zealand and China Present and Future, edited by Tim Beal and Yongin Zhang. Wellington, N.Z.: Victoria University Press, 1996.

Hughes Butts, Kent, and Geoffrey D. Dabelko. "One Way to Boost US-China Military Cooperation.” Christian Science Monitor. Accessed March 3, 2012. http://www.csmonitor.com/Commentary/Opinion/2009/0421/p09s01-coop.html/(page)/2.

Huxley, Tim. "The Future of the Five Power Defence Arrangements." The Strategist Australian Strategic Policy Institute, November 2012. http://www.aspistrategist.org.au/.

Indonesia Human Rights Committee. "Submission to Defence Review 2009," August 23, 2009. http://www.defence.govt.nz/pdfs/defence-review-2009-public-submissionsoia/171\%20-\%20Defence\%20Review\%2009\%20public\%20submission.PDF.

“Indonesia's Armed Forces SBP Vol6 P1 Nov2011.pdf.” Accessed August 6, 2012. http://www.victoria.ac.nz/css/Strategic_Briefing_Papers/Vol.6\%202011/Indonesia\%27s\% 20Armed\%20Forces\%20SBP\%20Vol6\%20P1\%20Nov2011.pdf.

International Defence Relations Branch. "New Zealand Defence Engagement with Southeast Asia." Ministry of Defence, December 1, 2009.

International Institute for Strategic Studies. "Fourth Plenary Session Humanitarian and Disaster Relief in the Asia-Pacific.” Shangri-La Dialogue 2010, June 5, 2010. www.iiss.org/conferences/the-shangri-la-dialogue/shangri-la-dialogue-2010/plenarysession-speeches/fourth-plenary-session/wayne-mapp.

Jakobson, Linda, and Dean Knox. New Foreign Policy Actors in China. Stockholm: Stockholm International Peace Research Institute (SIPRI), 2010.

Jha, Pankaj Kumar. "India's Defence Diplomacy in Southeast Asia." Journal of Defence Studies 5, no. 1 (January 2011).

Jian, Yang. "China in the South Pacific: a Strategic Threat?" New Zealand International Review 34, no. 1 (February 2009).

Joann Saw, ed. "Defence Diplomacy in South East Asia: Conference Report." Singapore: S. Rajaratnam School of International Studies, 2010.

Jocelyn Woodley. Projecting Our Voice: Major Power Relationships in Asia, the Responses of Regional Organisationas and the Implications for New Zealand. Wellington, N.Z.: Council for Security Cooperation in the Asia Pacific - New Zealand, 2011.

Jones, Phil. The Military Contribution to Soft Power: A Comparative Analysis. Seaford House Paper. London: Royal College of Defence Studies, 2010. 
Jordan, Thomas M., Douglas C. Lovelace, and Thomas-Durell Young. "Shaping" the World through Engagement: Assessing the Department of Defense's Theater Engagement Planning Process. Carlisle, PA: Strategic Studies Institute, U.S. Army War College, 2000.

Jung Sung-Ki. "Seoul Launches New Forum for Asia Pacific Security Talks.” Defense News Website (November 9, 2012).

http://www.defensenews.com/artcile/20121109/DEFREG03/311090007/Seoul-LaunchesNew-Forum-Asia-Pacific-Security-Talks.

KA Muthanna. "Military Diplomacy." Journal of Defence Studies, Institute for Defence Studies and Analyses 5, no. No. 1 (January 2011).

http://idsa.in/system/files/jds_5_1_kamuthanna.pdf.

Kaljurand, Riina. “A Long Way to Defence Diplomacy,” January 13, 2012.

http://www.icds.ee/index.php?id=73\&L=1\&tx_ttnews\%5Btt_news\%5D=254\&tx_ttnews $\% 5 \mathrm{BbackPid} \% 5 \mathrm{D}=100 \& \mathrm{cHash}=\mathrm{e} 5 \mathrm{f} 15 \mathrm{c} 0 \mathrm{ebe}$.

Kamphausen, Roy, David Lai, and Andrew Scobell. The PLA at Home and Abroad Assessing the Operational Capabilities of China's Military. Carlisle, PA: Strategic Studies Institute, U.S. Army War College, 2010. http://purl.access.gpo.gov/GPO/LPS126827.

Kang, Taek Goo. "Assessing China's Approach to Regional Multilateral Security Cooperation.” Australian Journal of International Affairs 64, no. 4 (August 2010).

Kaplan, Robert D. “The Geography of Chinese Power.” Foreign Affairs, June 2010.

Karniol, Robert. "Country Briefing: Vietnam - Off the Ground.” Jane's Defence Weekly, January 4, 2006.

Kelman, Ilan. "Disaster Diplomacy: Can Tragedy Help Build Bridges Among Countries?” UCAR Quarterly (Fall 2007).

Kember, James, Paul Clark, and New Zealand Asia Institute (University of Auckland). China and New Zealand : a Thriving Relationship Thirty Years On. Auckland, N.Z.: New Zealand Asia Institute, University of Auckland, 2003.

Kennaway, Richard. "Foreign Policy In A Vacuum." New Zealand International Review 25, no. 6 (2000): $2-5$.

. "FOREIGN POLICY IN A VACUUM: The Content of the Debate." New Zealand International Review 26, no. 1 (2001).

http://findarticles.com/p/articles/mi_6991/is_1_26/ai_n28124513/.

Khan, Shirley A. U.S.- China Military Contacts: Issues for Congress. RL32496.

Congressional Research Service, 2010.

Koerner, Wolfgang. Security Sector Reform: Defence Diplomacy. In Brief. Ottawa, Canada: Parliamentary Information and Research Service, 2006. www.parl.gc.ca/Content/LOP/researchpublications/prb0612-e.pdf.

Kumar Jha, Pankaj. "India's Defence Diplomacy in Southeast Asia." Journal of Defence Studies, Institute for Defence Studies and Analyses 5, no. 1 (January 2011). 
Laksmana, Evan A. "Defence Diplomacy in South East Asia: Trends, Prospects and Challenges." In From "Boots" to "Brogues": The Rise of Defence Diplomacy in Southeast Asia. RSIS Monograph 21. Singapore: S. Rajaratnam School of International Studies, 2011.

- "Stirring from Beyond the Borders? American Military Assistance and Defense Reform in Indonesia." Asia Centre, July 2011. http://ssrn.com/abstract=2056713.

Law (Editor), David. "Defence Attachés." Geneva Centre for the Democratic Control of Armed Forces (DCAF), Geneva, Switzerland, July 2007.

Leadbeater, Maire. Negligent Neighbour: New Zealand's Complicity in the Invasion and Occupation of Timor-Leste. Nelson, N.Z.: Craig Potton Publishing, 2006.

—. "New Zealand Trains Indonesia's Military." Peace Researcher no. 16 (August 1998): 13-14.

Zealand International Review 35, no. 5 (October 2010).

Leech, John. Asymmetries of Conflict: War Without Death. London: F. Cass, 2002.

Leifer, Michael. "Balance of Power Quietly Alive in Asia." Straits Times. January 5, 1996.

"Letter from Doug Law, Assistant Secretary Policy, Ministry of Defence to New Zealand Ambassador Jakarta," December 13, 1982. JAK30/4/1.

“Letter to New Zealand Defence Attache,” July 14, 1983. Jakarta File 30/4/1.

Li, N. Chinese Civil-Military Relations in the Post-Deng Era: Implications for Crisis Management and Naval Modernization. China Maritime Studies 4. Newport, R.I.: United States Naval War College, 2010.

Lucius, Robert E. "Pacific Partnership Visits Vietnam: Setting the Standard for Sea-based Humanitarian Cooperation.” Naval War College Review 60, no. 4 (Autumn 2007): 125133.

Lyon, Rod. The New Zealand Defence White Paper: a More Strategically-extroverted Kiwi? Policy Analysis 69. Barton A.C.T.: Australian Strategic Policy Institute, 2010.

Ma Zhengang. "China's Independent Foreign Policy of Peace." The RUSI Journal 143, no. 1 (1998): 1-4. doi:10.1080/03071849808446220.

Manyin, Mark E. U.S. - Viet Nam Relations in 2011: Current Issues and Implicatons for U.S. Policy. Washington D.C.: Congressional Research Service, May 18, 2012.

Matsuda, Yasuhiro. “An Essay on China's Military Diplomacy: Examination of Intentions in Foreign Strategy.” In NIDS Security Reports. No 7, 2006. www.nids.go.jp/english/publication/kiyo/pdf/bulletin_e2006_2_Matsuda.pdf. 
McAllister, Ian. Public Opinion in Australia Towards Defence, Security and Terrorism. Special Report 16. Australian Strategic Policy Institute, 2008.

http://www.aspi.org.au/publications/publications_details.aspx?ContentID=180.

Representative Views: Mass and Elite Opinion on Australian Security. Australian Strategic Policy Institute, 2005.

http://www.aspi.org.au/publications/publication_details.aspx?ContentID=75\&pubtype=5.

McCully, Murray. "Speech to the New Zealand Institute of International Affairs." Speeches, April 5, 2011. http://www.beehive.govt.nz/speech/speech-new-zealandinstitute-international-affairs-1.

McGibbon, Ian. “The Defence Dimension.” In Southeast Asia and New Zealand: A History of Regional and Bilateral Relations, edited by Anthony L. Smith, 7-31.

Singapore: Institute of Southeast Asian Studies, 2005.

McInnes, Colin. “Labour's Strategic Defence Review.” International Affairs 74, no. 4 (October 1, 1998): 823-845.

Mediansky, Fedor A. Australian Foreign Policy: Into the New Millenium. Melbourne, Australia: Macmillan, 1997.

Michael O'Heill. “U.K. Defense Policy: Modern Forces for the Modern World." Strategic Forum, National Defense University, Institute for Strategic Studies no. 157 (January 1999).

Mietzner, Marcus. The Politics of Military Reform in Post-Suharto Indonesia: Elite Conflict, Nationalism and Institutional Resistance. Policy Studies 23. Washington, D.C.: East-West Center, 2006.

Miles, Robert. "Indonesia Under the Spotlight." New Zealand International Review 17, no. 4 (August 1992).

Moore, Malcolm, and Praveen Swami. "Viet Nam Offers Cam Ranh Bay Navy Base to Foil China." The Telegraph, November 8, 2010.

http://www.telegraph.co.uk/news/worldnews/asia/Viet Nam/8116192/Viet Nam-offersnavy-base-to-foil-China.html.

Morini, Darryl. "Paradigm Shift: China's Rise and the Limits of Realism." Security Challenges 7, no. 1 (Autumn 2011).

Murphy, Jim. “The Need for Defence Diplomacy.” Jim Murphy's Blog, May 4, 2012. http://jimmurphymp.org/2012/05/04/the-need-for-defence-diplomacy/.

Murray, Craig. Murder in Samarkand: a British Ambassador's Controversial Defiance of Tyranny in the War on Terror. Edinburgh: Mainstream, 2007.

'Nasution Speaks of 'Frank' N.G. Talks.” Sydney Morning Herald, April 24, 1961. http://news.google.com/newspapers?id=DS9WAAAAIBAJ\&sjid=_OUDAAAAIBAJ\&pg $=7236 \% 2$ C6129706. 
Nation, R. Craig. "National Power." In Guide to National Security Issues: Theory of War and Strategy, edited by J. Boone Bartholomees. Vol. 1. 3rd ed. Carlisle, PA: U.S. Army War College, 2008.

National Institute for Defense Studies. "Asia Pacific Countries' Security Outlook and Its Implications for the Defense Sector." NIDS Joint Research Series No.5. Tokyo: The National Institute for Defense Studies, n.d.

New Zealand Army. "Collective Training." About Us, April 3, 2013.

http://www.army.mil.nz/about-us/what-we-do/our-training/collective.htm.

_. "International Engagements." What We Do, April 3, 2013.

http://www.army.mil.nz/about-us/what-we-do/international-engagements/default.htm.

—. "Mutual Assistance Programme (MAP)." Training. Accessed August 8, 2012. http://www.army.mil.nz/our-army/training/map.htm.

New Zealand Defence Force. 1999/2000 Purchase Agreement Between Minister of Defence and Chief of Defence Force for Year Ending 30 June 2000. Wellington, N.Z.: New Zealand Government, 1999.

. 2000/2001 Purchase Agreement Between Minister of Defence and Chief of Defence Force for Year Ending 30 June 2001. Wellington, N.Z.: New Zealand Government, 2000.

- 2001/2002 Purchase Agreement Between Minister of Defence and Chief of Defence Force for Year Ending 30 June 2002. Wellington, N.Z.: New Zealand Government, 2001.

- 2002/2003 Purchase Agreement Between Minister of Defence and Chief of Defence Force for the Year Ending 30 June 2003. Wellington, N.Z.: New Zealand Government, 2002.

\section{—. Annual Plan 2011/2012. Wellington: New Zealand Government, 2011.}

- Briefing to the Incoming Government 2005. Wellington N.Z.: New Zealand Government, 2005. www.nzdf.mil.nz/downloads/pdf/public-docs/nzdf-bim-2005.pdf.

—. "CDF in China." Korero (September 27, 2011).

- "Chapter One: Policy Framework." In DFO 67: Defence Force Orders for the Mutual Assistance Programme, 2005.

- "Closer Defence Relations Between New Zealand and Vietnam," September 16, 2009. http://asianz.org.nz/newsroom/regional-matters/nz-and-vietnam.

_. "Defence Diplomacy." Command and Staff College, March 16, 2011. http://www.nzdf.mil.nz/corporate/command-and-staff-college/defencediplomacy/default.htm.

- New Zealand Defence Doctrine Publication (NZDDP - D) Foundations of New Zealand Military Doctrine 2004. Wellington, N.Z.: New Zealand Government, 2004. 
New Zealand Defence Doctrine Publication (NZDDP - D) Foundations of New Zealand Military Doctrine 2012. Wellington, N.Z.: New Zealand Government, 2012.

New Zealand Defence Doctrine Publication (NZDDP) - D Foundations of New Zealand Military Doctrine 2008. Wellington, N.Z.: New Zealand Government, 2008. http://www.nzdf.mil.nz/downloads/pdf/public-docs/2008/nzddp-d-2008-ed-2.pdf.

New Zealand Defence Doctrine Publication (NZDDP-D) Foundations of New Zealand Military Doctrine 2008. Wellington, N.Z.: New Zealand Government, 2008.

New Zealand Defence Force Annual Report 2009. Wellington: New Zealand Government, 2009.

- New Zealand Defence Force Annual Report 2010. Wellington: New Zealand Government, 2010.

—. New Zealand Defence Force Annual Report 2011. Wellington: New Zealand Government, 2011.

- New Zealand Defence Force Capability Review. Wellington: New Zealand Government, 2000.

— New Zealand Defence Force Strategic Plan 2007-2011: Delivering Today, Building for Tomorrow. Wellington, N.Z.: New Zealand Government, 2007.

"NZ, China and Australia Link for Disaster Response Planning." Press Releases, October 28, 2012. http://www.nzdf.mil.nz/news/media-releases/2012/20121029ncaalfd.htm.

. "NZDF 2011/2012 Output Plan.” Accessed March 7, 2012. http://www.parliament.nz/NR/rdonlyres/2B1C43CE-8BEC-4C6F-B060DA64F23A88F5/194774/49SCFDT_EVI_00DBSCH_EST_10656_1_A188393_Standard Es.pdf.

Output Plan 2005 for Year Ending 30 June 2006. Wellington, N.Z.: New Zealand Government, 2005.

Output Plan 2006 for Year Ending 30 June 2007. Wellington, N.Z.: New Zealand Government, 2006.

—_. "People's Liberation Army Navy Visits NZ," October 8, 2007. www.scoop.co.nz/stories/PO0710/S00088.htm.

- "Recipients of the New Zealand Gallantry Star." New Zealand Defence Force, April 23, 2013. http://medals.nzdf.mil.nz/category/d/d3recipients.html.

- The 2013-2016 Statement of Intent. Wellington, N.Z.: New Zealand Government, 2013. www.budget.govt.nz/budget/pdfs/ise-v4/soi-nzdf-2013-16.pdf.

New Zealand Embassy Ha Noi. "First Visit by a Vietnamese Defence Minister to New Zealand.” News. Accessed May 25, 2013. http://www.nzembassy.com/vietnam/news/first-visit-by-a-vietnamese-defence-minister-to-new-zealand. 
"Viet Nam and New Zealand Release Joint Statement at End of Visit -

September 2009," September 12, 2009. http://www.nzembassy.com/viet-nam/news/vietnam-and-new-zealand-release-joint-statement-at-end-of-visit-september-2009.

New Zealand Government. Government Response to the Interim Report of the Foreign Affairs, Defence and Trade Committee on the Inquiry into "Defence Beyond 2000." Wellington, N.Z.: House of Representatives, 1998.

Government Response to the Report of the Foreign Affairs, Defence and Trade Committee on the Inquiry into Defence Beyond 2000. Wellington, N.Z.: House of Representatives, 1999.

“Talks with Viet Nam's Defence Minister." Press Releases: Jonathan Coleman, March 22, 2013. http://www.beehive.govt.nz/release/talks-viet-nam\%E2\%80\%99sdefence-minister.

Defence, 2000.

The Shape of New Zealand's Defence : A White Paper. New Zealand: Ministry of Defence, 1997.

New Zealand Green Party. "New Zealand Defence Force Connection To Military Violence In West Papua.” Press Releases: Catherine Delahunty, June 18, 2012. http://www.greens.org.nz/press-releases/new-zealand-defence-force-connection-militaryviolence-west-papua.

New Zealand Ministry of Defence. Defence Assessment July 2010. Wellington, N.Z.: New Zealand Government, 2010.

—. Defence of New Zealand: Review of Defence Policy 1987. Wellington, N.Z.: Government Printer, 1987.

—. Defence Review 1978. Wellington, N.Z.: Government Printer, 1978.

—. Defence Review 1983. Wellington, N.Z.: Government Printer, 1983.

—. Defence White Paper 2010. Wellington, N.Z.: New Zealand Government, 2010.

Government Defence Statement: a Modern, Sustainable Defence Force Matched to New Zealand's Needs. Wellington, N.Z.: New Zealand Government, 2001.

Management of the NZDF's Programme of International Commitments. Wellington, N.Z.: New Zealand Government, 2011. http://www.defence.govt.nz/pdfs/reports-publications/evaluation-report-7-2011management-of-the-nzdfs-programme-of-internationasl-commitments.pdf.

—. "Phase One - Land Forces and Sealift (November 2000)." New Zealand Defence Force Capability Reviews, November 2000. http://www.defence.govt.nz/reportspublications/nzdf-cap-rev/operational.html. 
Review of Defence Policy 1972: New Zealand's Defence Policy Perspectives. Wellington, N.Z.: Government Printer, 1972.

. The Defence of New Zealand 1991: A Policy Paper. Wellington, N.Z.: GP Print, 1991.

—. The Defence Question: a Discussion Paper. Wellington, N.Z.: Government Printer, 1985.

—. The Government's Defence Policy Framework. Wellington, N.Z.: New Zealand Government, 2000.

- The Shape of New Zealand's Defence: a White Paper. Wellington, N.Z.: New Zealand Government, 1997.

New Zealand Ministry of Foreign Affairs and Trade. "Links with Other Countries." New Zealand Foreign Affairs Review 37, no. 4 (1987).

"MFAT Releases Classified Files to Public," August 2, 2012.

http://www.mfat.govt.nz/Media-and-publications/Features/415-MFAT-ReleasesClassified-Files.php.

__. "New Zealand - Viet Nam Action Plan 2010-2013,” July 21, 2010.

_. "New Zealand Defence Force Staff College Visits Viet Nam," no date. http://www.nzembassy.com/viet-nam/news/new-zealand-defence-force-staff-collegevisits-viet-nam.

—. "New Zealand Navy Ship Visits Ho Chi Minh City." Vietnam News, April 24, 2013. http://www.nzembassy.com/viet-nam/news/new-zealand-navy-ship-visits-ho-chiminh-city.

Our Future with Asia. Wellington, N.Z.: New Zealand Government, 2007.

_. "Relationship Between New Zealand and Indonesia." Accessed August 5, 2012. http://www.nzembassy.com/indonesia/relationship-between-new-zealand-and-indonesia.

_. "Relationship Between New Zealand and Viet Nam," no date.

http://www.nzembassy.com/viet-nam/relationship-between-new-zealand-and-vietnam/new-zealand-and-viet-nam.

—. "Republic of Singapore." Countries, August 3, 2012.

http://www.mfat.govt.nz/Countries/Asia-South-and-Southeast/Singapore.php.

—. "Review of Maritime Patrol: MFAT Submission." Department of Prime Minister and Cabinet, November 2000.

New Zealand Parliament, and Ron Smith. A Response to the Parliamentary Select Committee Interim Report "Inquiry into Defence Beyond 2000." [Wellington N.Z.]:

House of Representatives, 1999. 
New Zealand Trade and Enterprise, and New Zealand Ministry of Foreign Affairs and Trade. Opening Doors to China: New Zealand's 2015 Vision. Wellington, N.Z.: New Zealand Government, 2012.

North Atlantic Treaty Organisation. "Jakarta International Defence Dialogue.” Accessed January 29, 2013. www.nato.int/cps/ennatolive/news_71727.htm.

_. "The Partnership for Peace Programme," March 5, 2012. http://www.nato.int/cps/en/natolive/topic_50349.htm.

Nottage, Richard. "The Role of Defence in Foreign Policy." Ministry of Foreign Affairs and Trade Record (August 1995): 17-19.

Novak, Lauren. "Public Salutes Defence Force." Adelaide Now. Accessed May 10, 2012. http://www.adelaidenow.com.au/news/national/public-salutes-defence-force/storye6frea8c-1226350327217.

Nye, Joseph. "Soft Power and Leadership.” Compass: A Journal of Leadership (Spring 2004).

- Soft Power: The Means to Success in World Politics. New York: Public Affairs, 2004.

O’Neill, Michael. U.K. Defense Policy: Modern Forces for the Modern World. Strategic Forum. Fort Lesley J. McNair, D.C.: Institute for National Strategic Studies, National Defense University, January 1999.

Office of the Secretary of Defence. "Special Topic: China's Military Engagement." In Annual Report to Congress: Military and Security Developments Involving the People's Republic of China. Washington, D.C.: United States Department of Defence, 2011.

Pai, Nitin. "The Case for Military Diplomacy.” Business Standard. April 18, 2011, sec. Opinion and Analysis. http://www.business-standard.com/india/news/-case-for-militarydiplomacy/432559/.

Palmer, Rebecca. "Flying the New Zealand Flag in China." Stuff Website, October 15, 2007. http://www.stuff.co.nz/national/17007/Flying-the-New-Zealand-flag-in-China.

PASOLS Secretariat. "Pacific Area Senior Officer Logistics Seminar Brochure." United States Pacific Command. Accessed November 11, 2011. http://www.docstoc.com/docs/35977312/PACIFIC-AREA-SENIOR-OFFICERLOGISTICS-SEMINAR-BROCHURE.

Pearce, Colonel. MAP Visit to South East Asia 26 September to 11 October 1981, November 10, 1981. Jakarta File 30/4/1.

Peters, Winston. “Security Policy Responses to a Challenging World." Speeches, December 13, 2006. http://www.beehive.govt.nz/speech/security-policy-responseschallenging-world. 
Poling, Gregory. "Dynamic Equilibrium: Indonesia's Blueprint for a 21st-Century Asia Pacific." Southeast Asia from the Corner of 18th \& K Streets IV, no. 5 (March 7, 2013): $1-4$.

PRC Ministry of Foreign Affairs. "China and New Zealand Relations 2009." China Daily. Accessed March 23, 2012.

http://www.chinadaily.com.cn/hellochina/newzealandambassador2009/200908/21/content_8598670.htm.

PRC Ministry of National Defense. China's National Defense. Beijing: Information Office of the State Council, 1998. http://www.china.org.cn/e-white/5/index.htm.

China's National Defense in 2000. Beijing: Information Office of the State Council, 2000. http://www.china.org.cn/e-white/2000/index.htm.

China's National Defense in 2002. Beijing: Information Office of the State Council, 2002. http://english.gov.cn/official/2005-07/28/content_17780.htm.

China's National Defense in 2004. Beijing: Information Office of the State Council, 2004. http://english.gov.cn/official/2005-07/28/content_18078.htm.

China's National Defense in 2006. Beijing: Information Office of the State Council, 2006. http://www.china.org.cn/english/features/book/194421.htm.

China's National Defense in 2008. Beijing: Information Office of the State Council, 2009. http://english.gov.cn/official/2009-01/20/content_1210227.htm.

China's National Defense in 2010. Beijing: Information Office of the State Council, 2011. http://news.xinhuanet.com/english2010/china/201103/31/c_13806851.htm.

The Diversified Employment of China's Armed Forces. Beijing: Information Office of the State Council, 2013. http://news.xinhuanet.com/english/china/201304/16/c_132312681.htm.

Pugsley, Chris. "Your Target - Jakarta." New Zealand Defence Quarterly no. 14 (Spring 1996).

Q+A: Susan Wood interviews Major General Dave Gawn. Interview by Susan Wood, April 21, 2013. http://www.scoop.co.nz/stories/PO1304/S00261/qa-susan-woodinterviews-major-general-dave-gawn.htm.

Quarterly Report New Zealand Defence Attache Indonesia January - March 1976, May 4, 1976. Jakarta File 30/2/2.

Quigley, Derek. Inquiry into Defence Beyond 2000: Interim Report of the Foreign Affairs, Defence and Trade Committee. Wellington, N.Z.: House of Representatives, 1998.

Inquiry into Defence Beyond 2000: Report of the Foreign Affairs, Defence and Trade Committee. Wellington, N.Z.: House of Representatives, 1999. 
Rabel, Roberto. New Zealand and the Viet Nam War: Politics and Diplomacy. Auckland, N.Z.: Auckland University Press, 2005.

Rajagopalan, Rajeswari Pillai. "Military Diplomacy: The Need for India to Effectively Use In It's Conduct of Diplomacy." [unknown]. Accessed September 4, 2011. http://orfonline.org/cms/export/orfonline/modules/analysis/attachments/Military\%20Dipl omacy_1191584397137.pdf.

Robinson, Colin. "The Transformation of an Ally? Present Status and Future Prospects for the New Zealand Defense Forces.” Center for Defense Information, January 2003.

Rolfe, James. "Why Shout at Soeharto?” New Zealand Defence Quarterly 16 (Autumn 1997): 13-16.

Rolfe, Jim. Anachronistic Past or Positive Future: New Zealand and the Five Power Defence Arrangements. CSS Working Paper 4/95. Wellington N.Z.: Centre for Strategic Studies, 1995.

Cutting Their Cloth: New Zealand's Defence Strategy. Barton, Australia: Australian Strategic Policy Institute, 2007.

—. "Defence for the Next Century." New Zealand International Review 23, no. 2 (April 1998): 6-9.

—. "Jousting with Jakarta.” New Zealand Defence Quarterly (Autumn 1995).

- New Zealand's Security: Alliances and Other Military Relationships. CSS Working Paper 10/97. Wellington, N.Z: Centre for Strategic Studies, 1997.

Rolls, Mark G. "The FPDA and Asia's Changing Strategic Environment: A View from New Zealand." In Five Power Defence Arrangements at Forty, edited by Ian Storey, Ralf Emmers, and Daljit Singh, 105-117. Institute of Southeast Asian Studies, 2011.

Royal United Services Association. "Defence Diplomacy: Transatlantic Perspectives," no date. http://rusi.org/research/studies/transatlantic/news/ref:N4567118C822D6/.

“Nick Harvey MP Delivers Keynote Address.” RUSI Analysis, July 7, 2010. http://www.rusi.org/analysis/commentary/ref:C4C3469BA71A88/.

RSIS Conference on Defence Diplomacy in Southeast Asia, Oleg Korovin, Jennifer Sim, Joann Saw, and S. Rajaratnam School of International Studies. "Defence Diplomacy in Southeast Asia: Conference Report, 30 November 2010, Singapore.” S. Rajaratnam School of International Studies, 2010.

Sachar, B. S. "Cooperation in Military Training as a Tool of Peacetime Military Diplomacy.” Strategic Analysis 27, no. 3 (September 8, 2003).

Sebastian, Leonard C., and Iisgindarsah. Assessing 12-year Military Reform in Indonesia: Major Strategic Gaps for the Next Stage of Reform. RSIS Working Paper 227. Singapore: S. Rajaratnam School of International Studies, 2011. 
Shadwick, Martin. "Defence And The International Policy Statement." Canadian Military Journal, July 14, 2008. http://www.journal.dnd.ca/vo6/no2/commenta-eng.asp.

Shambaugh, David. "China Engages Asia: Reshaping the Regional Order." International Security 29, no. 3 (Winter /2005 2004): 64-99.

Sharman, J.C., and Jacqui True. "Anglo-American Followers or Antipodean Iconoclasts? The 2008 TRIP Survey of International Relations in Australia and New Zealand." Australian Journal of International Affairs 65, no. 2 (2011).

Shelton, Henry H. "Shaping a Better World: Military Engagement in Peacetime." US Foreign Policy Agenda, December 1999.

http://www.usia.gov/journals/itps/1299/ijpe/ijpe1299.htm.

Simamora, Parulian. "The Current Status of Indonesia's Defence Diplomacy." presented at the The Current Status of Defence Diplomacy Workshop. Lesperssi Seminar, Jakarta, November 28, 2007.

Singapore Ministry of Defence. Defending Singapore in the 21st Century. Singapore: Singapore Government, 2000.

Singh, Bhubhindar, and See Seng Tan. 'From 'Boots' to 'Brogues': The Rise of Defence Diplomacy in Southeast Asia.” S. Rajaratnam School of International Studies, 2011.

Singh, Daljit. ASEAN's Perspective of New Zealand's Place in Asia. Outlook 2011 Series. Wellington N.Z.: Asia: New Zealand Foundation, 2011.

Smith, and Tom Peterman. "Report from the Conference on Evolving Roles of the Military in the Asia-Pacific." Honolulu, Hawaii: Asia Pacific Centre, 2000. http://www.apcss.org/Publications/Report_Evolving_Roles.html.

Socialist Republic of Viet Nam Ministry of National Defence. Vietnam National Defence. Ha Noi: Ministry of National Defence, 2009.

. Vietnam's National Defense in the Early Years of the 21st Century. Ha Noi: Ministry of National Defense, 2004.

Statistics New Zealand. "New Zealand in Profile: 2012 - Statistics New Zealand." Main Trading Partners, 2011 (NZ\$ Million). Accessed April 22, 2012. http://www.stats.govt.nz/browse_for_stats/snapshots-of-nz/nz-in-profile2012/imports.aspx.

Steiner, Barry H. "Diplomacy and International Theory." Review of International Studies 30, no. 4 (October 1, 2004): 493-509.

Stern, Lewis M. "Adding Strategic Depth of U.S.-Vietnamese Defense Relations." Stratfor, May 17, 2012. http://www.stratfor.com/other-voices/adding-strategic-depth-usvietnamese-defense-relations.

—. "Breaking Bread with the Vietnamese: Defense Secretary Panetta's June 2012 Visit to Cam Ranh and Hanoi." Stratfor, July 11, 2012. http://www.stratfor.com/other- 
voices/breaking-bread-vietnamese-defense-secretary-panetta\%E2\%80\%99s-june-2012visit-cam-ranh-and.

US-Vietnam Defense Relations: Deepening Ties, Adding Relevance. INSS CSR Strategic Forum. Washington D.C.: Institute for National Strategic Studies, 2009. http://kms1.isn.ethz.ch/serviceengine/Files/ISN/121075/ipublicationdocument_singledocu ment/5b304652-7017-4db7-898a-e70fa22e8fe1/en/SF246.pdf.

Sukma, Rizal. "Indonesia's Bebas-Aktif Foreign Policy and the 'Security Agreement' with Australia.” Australian Journal of International Affairs 51, no. 2 (1997).

_. "Indonesia's Security Outlook, Defence Policy and Regional Cooperation." In Asia Pacific Countries' Security Outlook and Its Implications for the Defence Sector. NIDS Joint Research Series 5. Tokyo: The National Institute for Defense Studies, 2010. http://www.nids.go.jp/english/publication/joint_research/series5/pdf/5-1.pdf.

"Supporting Essay 4: MoD Strategy for Defence Relations." In Delivering Security in a Changing World. Norwich: HMSO, 2003. http://www.voltairenet.org/IMG/pdf/esvolume2.pdf.

Taylor, Brendan. "The Rise of Asian Defense Diplomacy: Convergence or Divergence in Sino-Australian Security Relations.” Contemporary International Relations 21, no. 3 (June 2011): 169-185.

"Text: Joint Declaration of Cooperation Between NZ and Viet Nam." National Business Review (May 9, 2005). http://www.nbr.co.nz/article/text-joint-declaration-cooperationbetween-nz-and-viet-nam.

Thayer, Carlyle. "The Outlook for US-Vietnam Relations: Presentation to East-West Center, Washington D.C.," March 23, 2011.

http://www.scribd.com/doc/51880102/Thayer-US-Vietnam-Defence-Relations.

. "Vietnam's Defence Diplomacy and Its Impact on Foreign Relations.” Hamburg, Germany: Asien-Afrika Institut, Universitat Hamburg, 2008.

http://www.scribd.com/intasma/d/16447618-Carlyle-Thayer-Vietnams-DefenceDiplomacy-and-Its-Impact-on-Foreign-Policy.

2010. "Vietnam's Defensive Diplomacy." The Wall Street Journal Asia, August 20,

. "Vietnam's Security Outlook: Presentation to International Workshop of AsiaPacific Security. National Institute of Defence Studies, Tokyo, Japan," January 17, 2012. http://www.scribd.com/doc/78512624/Thayer-Vietnam\%E2\%80\%99s-Security-Outlook.

Thayer, Carlyle A. "Force Modernization: The Case of the Vietnam People's Army." Contemporary Southeast Asia 19, no. 1 (June 1997): 1.

Thayer, Carlyle A. "Background Briefing: Vietnam-United States Strategic Partnership." Thayer Consultancy, February 13, 2012.

Southeast Asia: Patterns of Security Cooperation. Barton, Australia: Australian Strategic Policy Institute, 2010. 
"The Five Power Defence Arrangements Exercises and Their Contribution to Regional Security, 2004-2010.” Traders Hotel, Singapore: S. Rajaratnam School of International Studies, 2011.

- "The Five Power Defence Arrangements: The Quiet Achiever." Security Challenges 3, no. 1 (February 2007): 79-96.

Thompson, Graham, Ravi Khosa, Chris Dain, Bob Mirtalee, and Mary Hockney. "Security Sector Reform Strategy 2004-2005." Governance and Social Development Resource Centre, 2004. http://www.gsdrc.org/docs/open/CON10.pdf.

Togo, Kazuhiko. "Regional Security Cooperation in East Asia: What Can Japan and Australia Usefully Do Together?" Australian Journal of International Affairs 65, no. 1 (2011): 40-60. doi:10.1080/10357718.2011.535586.

Tung, Liam. "China Accused of Cyberattacks on New Zealand - CNET News," September 13, 2007. http://news.cnet.com/China-accused-of-cyberattacks-on-NewZealand/2100-7348_3-6207678.html?tag=lia;rcol.

United Kingdom Ministry of Defence. Defence Diplomacy. Policy Paper 1. London: Director General Corporate Communication, 2000.

Defence Engagement Paper (Draft). London: Ministry of Defence, 2012.

Delivering Security in a Changing World: Defence White Paper 2003. Norwich: The Stationery Office, 2003.

Future Land Operating Concept. Joint Concept Note 2/12. Swindon:

Development, Concepts and Doctrine Centre, 2012.

Strategic Defence Review, July 1998.

http://webarchive.nationalarchives.gov.uk/20121026065214/www.mod.uk/NR/rdonlyres/ 65F3D7AC-4340-4119-93A2-20825848E50E/0/sdr1998_complete.pdf.

_. "Strategic Defence Review Seminar - 5 November 1997 Summary of Opening Remarks by George Robertson MP, Secretary of State for Defence," November 5, 1997. http://web.archive.org/web/20000302155910/http://www.mod.uk/policy/sdr/sem1197.ht $\mathrm{m}$.

—. Strategic Defence Review Supporting Essay Four: Defence Diplomacy, 1998.

_. "Strategic Defence Review: Summaries of Seminars Held on 3 and 11 July 1997." Accessed August 18, 2011.

http://web.archive.org/web/19980701120134/http://www.mod.uk/policy/sdr/sem0797.ht $\mathrm{m}$.

The Strategic Defence Review: A New Chapter. Norwich: United Kingdom The Stationery Office, 2002. http://merln.ndu.edu/whitepapers/UK_SDR_2002.pdf.

The Strategic Defence Review: A New Chapter. Supporting Information and Analysis. Vol. II. Norwich: United Kingdom The Stationery Office, 2002. 
United States Central Intelligence Agency. "Military: Vietnam." The World Factbook, January 7, 2013. https://www.cia.gov/library/publications/the-world-factbook/index.html.

United States Department of Defense, and Anthony Leehy. Military and Security Developments in China. Hauppauge N.Y.: Nova Science Publishers, 2011.

United States Department of State. "Preventing Conflict: Military Engagement in Peacetime." US Foreign Policy Agenda 4, no. 3 (December 1999).

_. "Vietnam." Country Reports on Human Rights Practices for 2011, 2011. http://www.state.gov/j/drl/rls/hrrpt/humanrightsreport/index.htm?dynamic_load_id=1863 1 .

United States Joint Staff. "Chairman of the Joint Chiefs of Staff Manual (CJCSM) 3113.01 Theater Engagement Planning," February 1, 1998. https://www.hsdl.org/?view\&did=2026.

"US Seeks Greater Military Ties with China." Agence France-Presse, January 27, 2012. http://www.google.com/hostednews/afp/article/ALeqM5iGmrtFboRvHxJCrS6PHE1Qa538A?docId=CNG.871f4204301feda9723a1cb343f5afe3.241.

Vaughn, Bruce. Indonesia: Domestic Politics, Strategic Dynamics and U.S. Interests. Washington, D.C.: Congressional Research Service, January 31, 2011.

Viet Nam Ministry of Foreign Affairs. "First ADMM+ Chairman's Statement," October 13, 2010.

http://www.mofa.gov.vn/en/nr040807104143/nr040807105001/ns101014100856/newsite m_print_preview.

Viet Nam News Agency. "New Zealand Naval Ship Visits Ho Chi Minh City." Footprint Travel, June 29, 2011. http://www.footprintsvietnam.com/Travelnews/2011/June/NewZealand-naval-ship-visits-Ho-Chi-Minh-City.htm.

"Vietnam in 2008: Foreign Policy Successes but Daunting Domestic Problems." Southeast Asian Affairs (2009): 373-388.

“Vietnam's Defence White Paper.” Southeast Asian Affairs (1999): n/a.

White, Hugh. "The Limits to Optimism: Australia and the Rise of China." Australian Journal of International Affairs 59, no. 4 (2005).

Wilkins, Thomas. “The New 'Pacific Century' and the Rise of China: An International Relations Perspective.” Australian Journal of International Affairs 64, no. 4 (August 2010): 381-405. doi:10.1080/10357718.2010.489993.

Willard, James E. "Military Diplomacy: An Essential Tool of Foreign Policy at the Theater Strategic Level." School of Advanced Military Studies, Fort Leavenworth Kansas, May 25, 2006. http://www.dtic.mil/cgi-bin/GetTRDoc?AD=ADA450837.

Wimmel, Kenneth. Theodore Roosevelt and the Great White Fleet: American Sea Power Comes of Age. Brassey's, 2000. 
Woodman, Stewart. "Back to the Future." New Zealand International Review 23, no. 2 (March 1998): 2-5.

World Trade Organisation. "WTO | Accession Status: Viet Nam," 2012. http://www.wto.org/english/thewto_e/acc_e/a1_vietnam_e.htm.

"Wp11.pdf." Accessed April 22, 2012.

http://www.victoria.ac.nz/css/docs/working_papers/wp11.pdf.

Xinhua News Agency. "China, New Zealand Pledge to Further Military Cooperation." China News, December 19, 2012. http://news.xinhuanet.com/english/china/201212/19/c_132051487.htm.

_. "China-New Zealand Bilateral Relations." China Daily, April 3, 2006. http://www.chinadaily.com.cn/china/2006-04/03/content_558411_5.htm.

—. "Chinese Defense Minister Meets New Zealand Counterpart," June 4, 2011. http://news.xinhuanet.com/english2010/china/2011-06/04/c_13910915.htm.

"Xu Huizi." China Vitae. Accessed March 26, 2013.

http://www.chinavitae.com/biography/Xu_Huizi/full.

Yang Biao, and Deng Youbiao. "Chinese and New Zealand Warships Carry Out Joint Maneuver Exercise.” PRC Ministry of National Defense, September 16, 2010. http://eng.mod.gov.cn/MilitaryExercises/2010-09/16/content_4194059.htm.

Yates, Athol. "What Defence Really Does." Canberra Times, July 2, 2010, sec. Opinion. http://www.canberratimes.com.au/opinion/what-defence-really-does-2012070121 am5.html.

Yongjin Zhang. "Relationship Dynamics and Strategic Calculus: A Chinese Perspective." In China and New Zealand: A Thriving Relationship Thirty Years On, edited by James Kember and Paul Clark, 87-98. Auckland, N.Z.: New Zealand Asia Institute, University of Auckland, 2003.

York, Michael. New Zealand: National Involvement in the Indian Ocean Region. Strategic Analysis Paper. Perth, Australia: Future Directions International, December 17, 2012. http://www.futuredirections.org.au/files/sap/2012/FDI_Strategic_Analysis_Paper__17_December_2012.pdf.

Young, Audrey. "US Keen on NZ-China Link." New Zealand Herald, December 17, 2012. http://www.nzherald.co.nz/nz/news/article.cfm?c_id=1\&objectid=10854525.

Yudhoyono, H Susilo Bambang. "IISS Keynote Address.” Accessed August 9, 2012. http://www.iiss.org/conferences/the-shangri-la-dialogue/shangri-la-dialogue2012/speeches/opening-remarks-and-keynote-address/keynote-address/.

Zipper de Fabiani, Henry. "Diplomatie de Défense et Diplomatie Préventive Vers Une Nouvelle Symbiose entre Diplomatie et Défense - Centre Thucydide - analyse et recherche en relations internationales." Annuaire Francais des Relations Internationales 3 (2002). http://www.afri-ct.org/The-defence-diplomacy-main?lang=fr. 